Michelle Buscarilli de Moraes

\title{
Análise do status somático dos genes MEN1, AIP e p27Kip1 em tumores de pacientes com neoplasia endócrina múltipla tipo 1
}

Dissertação apresentada à Faculdade de Medicina da Universidade de São Paulo para a obtenção do Titulo de Mestre em Ciências

Programa de: Endocrinologia

Orientador: Prof. Dr. Sergio Pereira de Almeida Toledo

São Paulo

2012 
Dados Internacionais de Catalogação na Publicação (CIP)

Preparada pela Biblioteca da

Faculdade de Medicina da Universidade de São Paulo

\section{Creprodução autorizada pelo autor}

Moraes, Michelle Buscarilli de

Análise do status somático dos genes MEN1, AIP e p27Kip1 em tumores de pacientes com neoplasia endócrina múltipla tipo 1 / Michelle Buscarilli de Moraes. -- São Paulo, 2012

Dissertação(mestrado)--Faculdade de Medicina da Universidade de São Paulo. Programa de Endocrinologia.

Orientador: Sérgio Pereira de Almeida Toledo.

Descritores: 1.Neoplasia endócrina múltipla tipo 1 2.Perda de heterozigosidade 3.Genes supressores de tumores 4.Tumores/análise

USP/FM/DBD-131/12 


\section{DEDICATÓRIA}

À Deus, pelo amor ágape, iluminando meu caminho, sempre com sabedoria;

Aos meu pais, pelo apoio e amor incondicional, pela dedicação, base familiar, amor e paciência.

Ao meu irmão pela força

Ao meu orientador Prof. Dr. Sergio P. A. Toledo e ao Dr. Rodrigo de Almeida Toledo, por serem um exemplo de generosidade em todos os ensinamentos transmitidos. 


\section{AGRADECIMENTOS}

Ao longo da vida, encontramo-nos com pessoas muito especiais. Assim posso definir todos da Unidade de Endocrinologia, que não só colegas de trabalho, transformaram-se em grandes amigos. Gostaria de agradecer cada um pelos momentos divididos que jamais serão esquecidos.

Em primeiro lugar, a Deus por transmitir seu amor ágape, sempre iluminando meu caminho e permitindo que eu complete mais um ciclo na minha vida.

Aos meus pais, Ailton Paulo de Moraes e Vani Buscarilli de Moraes, a vocês não bastaria apenas um muito-obrigada. O que dizer de vocês, pessoas que me ensinaram tudo que sei, ensinaram-me a viver. Que me ampararam nas horas em que mais precisava, sabendo dizer, na dose certa, uma palavra amiga quando precisava de consolo, uma dura quando precisava de correção, sempre com sabedoria e justiça. A figura de vocês representa todo amor, respeito e consideração que possa existir. Sua honestidade e força são exemplo de vida e me dão o rumo do caminho que vou seguir. Queria poder retribuir, um dia, todo carinho e atenção que me deram. Ensinaram a andar e estavam lá, quando precisava para amparar minha queda. Ensinaram-me a falar e estavam lá para corrigir minhas palavras, a escrever e estavam lá para orientar meus primeiros rabiscos. Ensinaram-me a viver e tenho certeza de que posso contar com vocês em qualquer fase da minha vida, nos bons e maus momentos, sempre com dedicação e prontidão.

Espero poder, um dia, representar para meus filhos tudo aquilo que representam para mim, pois cultivo por vocês os sentimentos mais puros e verdadeiros que podem existir: o amor, o carinho, o respeito, e acima de tudo a admiração.

Agradeço todos os dias por poder compartilhar da companhia e convívio com vocês e, principalmente, por poder me orgulhar de ter vocês, pai 
e mãe, como também meus amigos, e por fazer parte de uma família, que cultiva os melhores sentimentos que existem: a paz, a compreensão e o respeito mútuo. Obrigada por tudo. Obrigada por serem pais maravilhosos. Obrigada por guiarem meus passos e por incentivarem, a cada dia, meus sonhos e objetivos. Obrigada pela oportunidade de me fazerem alguém, para que eu possa retribuir, ao menos, um pouco de tudo que recebi de vocês.

Ao meu querido irmão, Wesley Buscarilli de Moraes, por todo apoio, amor e carinho e prontidão sempre quando precisei, amo você.

À todos da minha família tios (as), primos (as) por todo carinho, apoio.

Ao Prof. Dr. Sergio Pereira de Almeida Toledo, minha gratidão, admiração e respeito pela oportunidade da orientação e de desenvolver este trabalho na Unidade de Endocrinologia Genética (LIM25). Não sei o que é maior o orgulho ou privilégio de ser sua orientanda.

Ao Dr. Rodrigo de Almeida Toledo, minha gratidão pela atenção sincera e disponível, quem me fez enxergar minha paixão pela pesquisa, sempre com muita paciência, transmitindo seus conhecimentos de forma clara, sendo para mim um exemplo de profissional, transformando um objetivo em realidade, obrigada por tudo.

Ao Dr. Delmar Lourenço Junior, minha gratidão pela colaboração deste trabalho, fornecendo os dados clínicos.

À Dra Flávia Coutinho, Dra. Tatiana Denck, Elisangela Quedas e Camila Quedas, minha gratidão pela presteza e dedicação, por se transformarem em não só grandes companheiras de trabalho, mas grandes amigas, parceiras na qual pude dividir muitos momentos de alegrias e sei que o nosso crescimento profissional e cientifico continuara de forma impar.

Aos profissionais do Hospital das clínicas- Faculdade de medicina da USP, em especial aos funcionários: Eliete Helena, Dra. Joya Emilie, Geni Rodrigues, Graça Cavalcanti, através de seu convívio agradável, permitindo a conclusão deste trabalho de forma tranquila. 
As amigas do Lim 25 "vizinho" " (grupo Tireóide), Ester Brust, Érica Urbano e Ana Luiza, por todo apoio alegria e convívio agradável e pela amizade que as levarei comigo.

Aos membros da banca de qualificação: Dra. Ana Hoff, Dra Maria Cândida Fragoso e Dr. Ricardo Giorgi, por contribuírem com preciosas sugestões, acrescentados na finalização deste trabalho.

Ao Dr. Alexander Augusto de Lima Jorge por todo apoio, e por permitir minha conclusão de mestrado na UEG.

Aos pós-graduandos da Unidade de Endocrinologia genética, por dividirem comigo a prática profissional e momentos de descontração.

À Cida secretária da pós-graduação por todo auxilio e dedicação.

A todos os pacientes e familiares pela sua compreensão, por acreditar em nosso trabalho em prol da evolução científica, sobrepondo suas aflições tornando assim, este estudo possível.

À FAPESP, pelo apoio financeiro e cientifico.

A todas minhas amigas, que compreenderam bastantes vezes minhas ausência, obrigada pelo incentivo, carinho, amizade verdadeira, vocês fazem parte da concretização deste trabalho.

A todos, de forma geral, os meus imensos e infindáveis agradecimentos. 
"A vitória vem de uma vontade de fazer tudo certo, do início ao fim, de não se permitir errar, mas de dar de si o máximo absoluto."

(Ayrton Senna) 


\section{Sumário}

Lista de Abreviaturas

Lista de Figuras

Lista de Tabelas

Resumo

Summary

1. INTRODUÇÃO 1

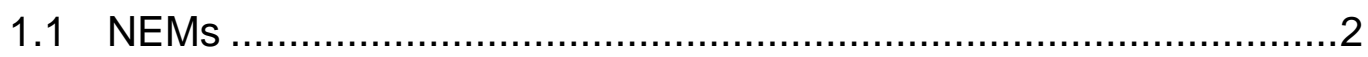

1.2 Neoplasia Endócrina Múltipla Tipo 1 ........................................5

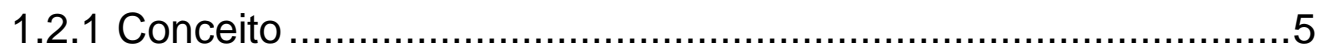

1.3 Aspectos Clínicos da NEM1 ….......................................... 8

1.3.1 Hiperparatireoidismo ...................................................8

1.3.2 Tumores Entero-Pancreáticos na NEM1 ...............................11

1.3.2.1 Gastrinoma.......................................................... 11

1.3.2.2 Insulinoma ............................................................ 11

1.3.2.3 Adenomas hipofisários ......................................... 12

1.3.2.4 Outros tumores na NEM1 .......................................13

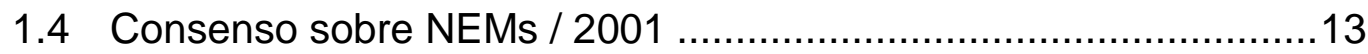

1.5 Critérios para rastreamento genético MEN1 .............................14

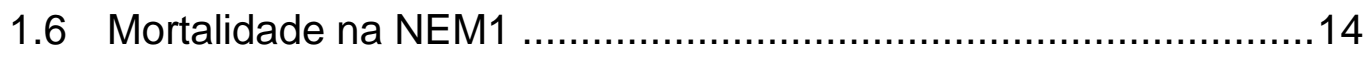

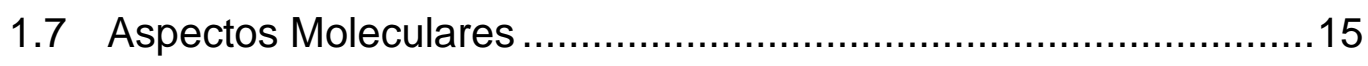

1.7.1 Clonagem do gene MEN1 ............................................ 15

1.7.2 Proteína MENIN, codificada pelo gene MEN1 .......................16

1.8 Modelo animal da NEM1 ...............................................20

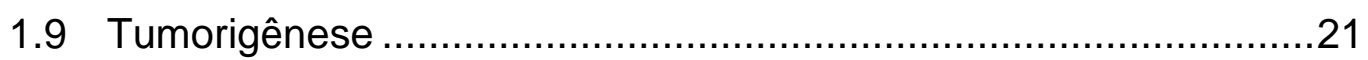

1.10 Estudo de perda de heterozigose em tumores de pacientes com NEM1.

1.11 Evidências do envolvimento de outro(s) gene(s) na NEM1. .25 
1.12 Novos genes recentemente associados à NEM1 e a doenças

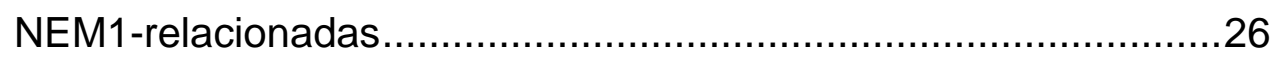

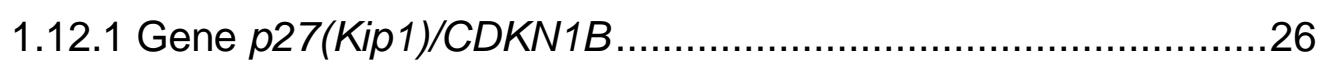

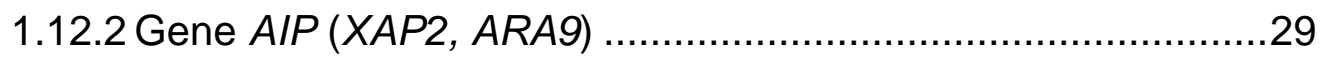

1.12.3 Genes CDKN2B/P15, CDKN2C/P18 e CDKN1A/P21 .............30

1.13 Metodologia para análise de perda de heterozigose $(\mathrm{LOH})$...........31

1.13.1 Polimorfismos de microssatélites ..........................................31

1.13.2 Análise de perda de heterozigose por análise de mutação .....32

2 OBJETIVOS

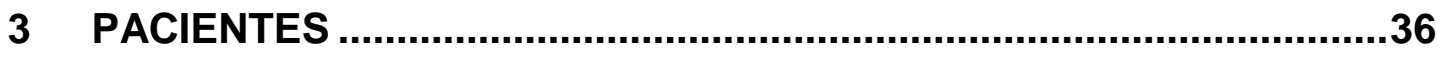

4 MÉTODOS

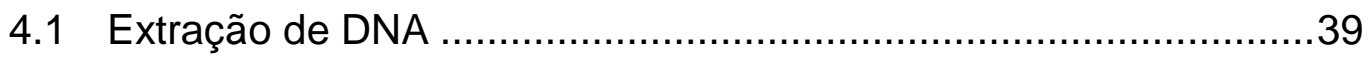

4.2 Eletroforese em gel de agarose .............................................40

4.3 Amplificação Gênica ............................................................40

4.4 Purificação dos produtos de PCRS ……………........................41

4.5 Reação de Sequenciamento ...................................................... 41

4.6 Reação de Precipitação ............................................................42

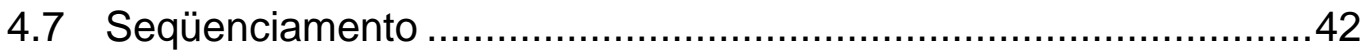

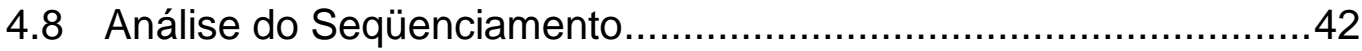

4.9 Estudo de perda de heterozigose (LOH) do locus do gene MEN1

4.10 Análise de mutação somática e de LOH do gene CDKN1B em tumores de pacientes com NEM1

4.11 Análise de mutação somática e de LOH do gene AIP em tumores de pacientes com NEM1. 
5.1 Análise somática do gene MEN1 em tumores de pacientes com

NEM1 por seqüenciamento gênico .48

5.2 Análise de LOH por marcadores de microssatélites .58

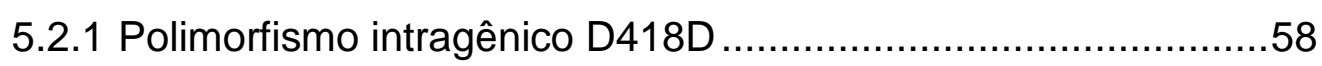

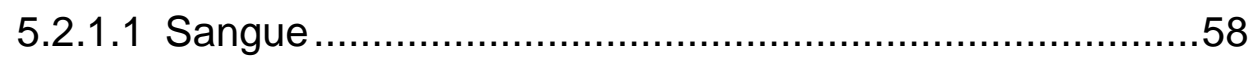

5.2.1.2 Adenoma de paratireóide e tumor de pâncreas ..............60

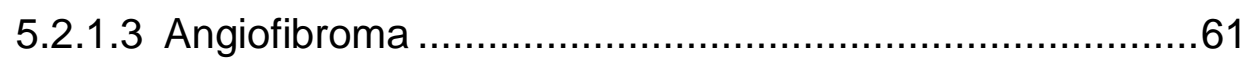

5.2.2 Análise de LOH com o marcador de microssatélite PYGM .......64

5.3 Análise de mutação somática do gene p27Kip1 em tumores NEM1 .66

5.3.1 Análise de LOH no gene p27Kip1 em tumores NEM1 .66

5.4 Análise de $\mathrm{LOH}$ no gene AIP em tumores NEM1 .79

5.4.1 Análise de perda de heterozigose com o marcador de microssatélite D11S1258. .79

5.4.2 Análise de LOH com o marcador de microssatélite D11S2072 .82

6 DISCUSSÃO .84

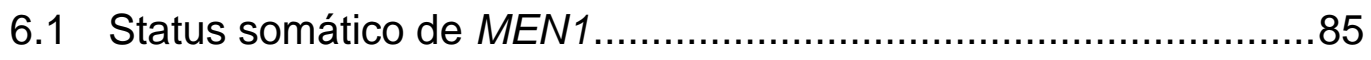

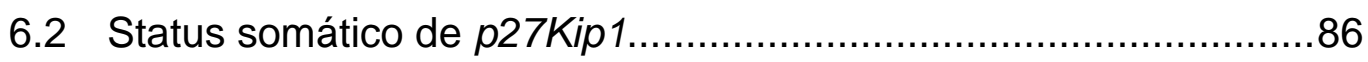

6.3 Manifestações clínicas associadas a perda somática de $p 27 \ldots \ldots \ldots \ldots . . .87$

6.4 Status somático de AIP

7 CONCLUSÃO. .89

8 REFERÊNCIAS .91 


\section{Lista de Abreviaturas}

Ca: Cálcio sérico

FMUSP: Faculdade de Medicina da Universidade de São Paulo

HPT: Hiperparatiroidismo primário

HPT/e: Hiperparatireoidismo primário esporádico

LOH: Perda de heterozigose, referente à inativação somática de gene supressor de tumor (LOH, do inglês Loss of Heterozygosity)

MOH: Manutenção de heterozigose

NEMs: Neoplasias Endócrinas Múltiplas

NEM1: Neoplasia Endócrina Múltipla tipo 1

NEM2: Neoplasia Endócrina Múltipla tipo 2

NF-1: Neurofibromatose tipo 1

NL: Normal

PCR: Polymerase Chain Reaction

PRKAR1A: Protein Kinase A (PKA) type 1-a regulatory subunit (Rla)

PTH: paratormônio

PTX: paratireoidectomia total com implante no antebraço

SNC: Sistema Nervoso Central

TEPs: tumores entero-pancreáticos

VHL: Von Hippel-Lindau 


\section{Lista de Figuras}

Figura 1: Ilustração das principais glândulas afetadas na NEM1 e NEM2 (Marx 2005)

Figura 2: Cintilografia evidenciando o acometimento uniglandular no HPT esporádico e o multiglandular em casos com NEM1

Figura 3: Ação da proteína MENIN integra associada ao fator de transcrição JunD, a MENIN revertendo o efeito da JunD na indução ao crescimento e ao inicio do ciclo celular

Figura 4: Ação da MENIN em indivíduos com NEM1 (Marx, 2005)

Figura 5: O produto do gene MEN1 é a proteína supressora de tumor chamada MENIN. Por exercer funções essenciais, como controle do ciclo e do crescimento celular, regulação da transcrição gênica através de interações com a JunD (adaptado de Balog, 2006).

Figura 6: Modelo multistep da tumorigênese em tumores Hipofisários. Nota-se a ocorrência de diversos eventos genéticos que controlam a evolução de uma hipófise normal até a formação de um adenoma invasivo. (adptada de Boikos \& Stratakis 2007)

Figura 7: Tumorigênese na NEM1. Modelo de dois eventos mutacionais para genes supressores de tumor, como o MEN1 (Knudson, 1971; Agarwal, 1999)

Figura 8: Interação da proteína MENIN com a CDKN1B

Figura 9: Representação do gene p27Kip1, com a presença dos polimorfismos V109G e C-79C > T

Figura 10: Genes envolvidos na regulação do ciclo celular. (CDKN2B/p15, CDKN2C/p18, CDKN1A/p 21, CDKN1B/ p27) recentemente associados à NEM1

Figura 11: Análise de LOH por seqüenciamento gênico, análise em pontos específicos, na qual a mutação já é conhecida.

Figura 12: $O$ eletroferogramada acima mostra a sequencia controle do gene MEN1 e abaixo a sequencia do tumor, com clara evidencia de LOH no tumor 194 (paratireóide), de paciente com mutação germinativa com deleção de $25 \mathrm{pb}$

Figura 13: O eletroferogramada acima mostra a sequencia controle do gene MEN1 e abaixo a sequencia do tumor, com clara evidencia de LOH no tumor 206 (pâncreas), de paciente com mutação germinativa com deleção de 4 pb 
Figura 14: O eletroferogramada acima mostra a sequencia controle do gene MEN1 e abaixo a sequencia do tumor, com clara evidencia de LOH no tumor 203 (paratireóide), de paciente com mutação germinativa IVS3+1G>T

Figuras 15,16 e 17 : Genotipagem do polimorfismo D418D, localizado no éxon 9 do gene MEN1, nas amostras de DNA de leucócitos de pacientes com NEM1. Foram identificados os alelos $\mathrm{C}$ e $\mathrm{T}$ e os genótipos CC e CT

Figuras 18 e 19: A genotipagem do polimorfismo D418D mostrou perda do alelo T no DNA do tumor, evidenciando perda do alelo normal do gene MEN1 nas células tumorais

Figura 20: A genotipagem do polimorfismo D418D nas células do tumor angiofibroma revelou o genótipo $\mathrm{C} / \mathrm{T}$, indicando manutenção de heterozigose.

Figura 21: O primeiro eletroferograma do sequenciamento do éxon 1 do gene p27Kip1 em sangue de paciente com mutação germinativa MEN1 mostra a presença dos dois alelos (G e T) do polimorfismo V109G na amostra de DNA do sangue, enquanto nos sequenciamentos abaixo, dos tumor de pâncreas desse paciente, nota-se maior prevalência do alelo T. Esse resultado indica a ocorrência de LOH-p27Kip1 nesse tumor, um gastrinoma metastático, diagnosticado aos 37 anos de idade.

Figura 22: Nota-se maior prevalência do alelo selvagem, $G$, no seqüenciamento do DNA de sangue do paciente NEM1 com mutação no gene $M E N 1$ e maior prevalência do alelo T no DNA do tumor de paratireóide. Esse resultado indica LOH-p27Kip1

Figuras 23 e 24: Acima, podemos identificar a presença de dois alelos nas células do sangue. Abaixo, observamos a ausência da amplificação de um dos alelos, indicando perda de heterozigose nas células tumorais do adenoma de paratireóide.

Figura 25: Análise de LOH por marcador D11S, 1258, onde os e três tumores de pâncreas e uma neoplasia de paratireoide apresentaram evidencias claras de LOH.

Figuras 26 e 27: Observamos a amplificação de dois alelos do marcador D11S 1258 no sangue e nas células do tumor de pele colagenoma 


\section{Lista de Tabelas}

Tabela 1: Caracterização Clínica e genética das Neoplasias Endócrinas Múltiplas.

Tabela 2: Frequência de tumores endócrinos e não-endócrinos na NEM1

Tabela 3: Mutações descritas na literatura no gene $C D K N 1 B$

Tabela 4: Lista dos primers utilizados para a análise dos marcadores de microssatélites localizados na região 11q13/MEN1

Tabela 5: Lista dos oligonucleotídeos utilizados para estudo genético do MEN1

Tabela 6: Lista dos primers utilizados para a análise localizados no gene $p 27 K i p 1 / C D K N 1$.

Tabela 7: Lista dos primers utilizados para a análise dos marcadores de microssatélites localizados na região 11q13/AIP

Tabela 8: Lista do primer utilizado para a análise localizados no gene AIP

Tabela 9: Análise do status somático do gene MEN1

Tabela 10: Resumo dos achados do status somático do gene MEN1 em tumores NEM1

Tabela 11: Resultados da genotipagem do polimorfismo intragênico D418D nas células de leucócitos e de tumores de pacientes com NEM1. Dois alelos foram identificados $\mathrm{C}$ e $\mathrm{T}$ e dois genótipos CC e CT. Em negrito estão as analises que demonstraram perda de heterozigose $(\mathrm{LOH})$ ou manutenção de heterozigose $(\mathrm{MH})$

Tabela 12: Resultados de análises de DNA leucocitário e tecidos de pacientes com NEM1 através do marcador de microssatelite PYGM. Em negrito as análises que mostraram perda alélica, ou seja, inativação do gene MEN1 
Tabela 13: Análise do status somático do gene p27Kip1

Tabela 14: Resultados de análises de DNA leucocitário e tecidos de pacientes com NEM1 através do marcador de microssatélite D11S1258.Em negrito estão as análises informativas que mostraram manutenção ou perda de heterozigose do tumor ....81

Tabela 15: Resultados de análises de DNA leucocitário e tecidos de pacientes com NEM1 através do marcador de microssatélite D11S2072. Em negrito as análises que mostraram manutenção de heterozigose 


\section{Resumo}

Moraes MB. Análise do status somático dos genes MEN1 e p27Kip1 em tumores de pacientes com neoplasia endócrina múltipla tipo [dissertação] São Paulo: Faculdade de Medicina, Universidade de São Paulo; 2012. 100p.

Aproximadamente $80 \%$ dos casos com Neoplasia endócrina múltipla tipo 1 (NEM1) possuem mutações germinativas no gene supressor de tumor MEN1, que os predispõem a tumores nas glândulas paratireóides, pâncreas endócrino e hipófise, além de outros tumores não endócrinos. A tumorigênese dos mais de 20 diferentes tipos de neoplasias já descritas na NEM1 ocorre pela presença da mutação germinativa MEN1 associadas a um segundo evento mutacional nas células desses tecidos, levando à perda de heterozigose (LOH) do locus do gene MEN1 (11q13) e à inativação da proteína supressora de tumor codificada por esse gene, a proteína MENIN. Recentemente, mutações germinativas em outros genes foram descritas em casos com NEM1 sem mutações no gene MEN1. Esses novos genes (CDKN1A, CDKN1B, CDNK2B e CDKN2C) codificam proteínas envolvidas no controle do ciclo celular (p21, p27, p15 e p18), chamadas proteínas inibidoras de quinases dependentes de ciclinas. Outro gene, chamado AIP, que codifica uma proteína chaperona de mesmo nome, também foi recentemente descrito associado à NEM1. Esses trabalhos descreveram o papel desses novos genes na NEM1, em nível germinativo, entretanto não esclareceu se esses novos genes estão inativados nos tumores de pacientes com NEM1 com mutação MEN1. O presente estudo investigou, pela primeira vez, o status somático do gene p27Kip1 em pacientes com mutação MEN1 e identificou quatro possíveis perda de heterozigose (LOH) em tumores de paratireóides e pâncreas, sugerindo que além de 11q13LOH, os tumores NEM1 podem sofrer raras perdas adicionais do gene supressor tumoral p27Kip1. Essas são as primeiras evidências na literatura de um processo de tumorigênese multi-step na NEM1, envolvendo três eventos genéticos: 1Mutação germinativa MEN1; 2- 11q13-LOH; 3- Perda somática do gene supressor de tumor $p 27 K i p 1 / C D K N 1 B$

Descritores: 1.Neoplasia endócrina múltipla tipo 1 2.Perda de heterozigosidade 3.Genes supressores de tumores 4.Tumores/análise 


\section{Summary}

Moraes MB. Analysis of the status of somatic and p27Kip1 genes in tumors from patients with multiple endocrine neoplasia type 1 [dissertation] São Paulo: "Faculdade de Medicina, Universidade de São Paulo"; 2012. 100p.

Approximately $80 \%$ of cases with multiple endocrine neoplasia type 1 (MEN1) harbor a germline mutation in the tumor suppressor gene MEN1, which predisposes these patients to tumors comprehending the parathyroid and pituitary glands, endocrine pancreas and others non-endocrine tumors. The tumorigenesis of the more than 20 different types of tumors already described in the MEN1 syndrome occurs due to a MEN1 germline mutation associated with a second mutational event in the cells of these tissues, leading to loss of heterozygosity (LOH) of the MEN1 gene locus (11q13) and therefore inactivation of tumor suppressor protein encoded by this gene, MENIN protein. Recently, germline mutations in other genes have been described in cases with MEN1 without any detectable mutations in the MEN1 gene. These novel genes (CDKN1A, CDKN1B, CDNK2B and CDKN2C) encode proteins involved in the control of the cell cycle (p21, p27, p15 and p18), called cyclin dependent kinases inhibitors. Another gene, called AIP, which encodes a chaperon protein with the same name, was recently described associated with MEN1 phenotypes. These data described a role for these novel genes in the germline level, however whether they are inactivated in tumors of patients with MEN1 mutation is so far not clarified. The present study investigated for the first time, the somatic status of p27KIP1 gene mutation in patients with MEN1 and identified four possible loss of heterozygosity ( $\mathrm{LOH}$ ) in tumors of the parathyroid and pancreas, suggesting that in addition 11q13-LOH, MEN1 tumors may suffer rare loss additional tumor suppressor gene p27KIP1. These are the first evidence in the literature of a process of tumorigenesis in MEN1 multi-step, involving three genetic events: 1-MEN1germlinemutation; 2-11q13LOH; 3-Loss of somatic tumor suppressor gene p27Kip1/CDKN1B.

Descriptors: 1.Multiple endocrine neoplasia type 12 .Loss of heterozygosity 3.Tumor suppressor genes 4.Tumors/analysis 
1 INTRODUÇÃO 
Os grandes avanços apresentados pela biologia molecular nos últimos anos têm tido forte impacto nas áreas do diagnóstico e tratamento, cirúrgico e/ou medicamentoso, das doenças genéticas hereditárias em geral.

As Neoplasias Endócrina Múltiplas (NEMs) são exemplos típicos desta situação. Assim, o rastreamento genético de mutações nos genes MEN1 e RET, responsáveis, respectivamente, pelas neoplasias endócrinas tipo 1 (NEM1) e tipo 2 (NEM2), permitiu a identificação e o tratamento de portadores de susceptibilidade à doença em idades precoces, nas quais os pacientes ainda não manifestam abertamente os sinais/sintomas clínicos da doença (fase assintomática). Essa abordagem genética tem contribuído à redução da mortalidade e morbidade dos pacientes e de seus familiares sob-risco, tanto na NEM1 como na NEM2 (Toledo et al, 2006; Lourenço et al. 2007).

\subsection{NEMs}

As NEMs são síndromes clinicamente complexas, que envolvem diversos tumores, endócrinos e não-endócrinos, benignos e malignos. Os tumores associados às NEMs são geralmente múltiplos (ocorrem em diversos órgãos) e multicêntricos (vários tumores primários em um mesmo órgão) e podem se desenvolver tanto precocemente, (jovens/ adolescentes) como mais tardiamente (fase adulta), de forma sincrônica ou assincrônica. 
As principais NEMs incluem: NEM1, NEM2, Von Hippel-Lindau (VHL), Complexo de Carney e Neurofibromatose (Tabela 1) (Marx et al 1999). A classificação das NEMs é usualmente feita de acordo com as glândulas afetadas e os genes envolvidos. Essas síndromes são caracterizadas pela presença de mutações que levam à inativação de genes de supressores de tumor (como no caso da NEM1), ou ativação de proto-oncogenes (como no caso da NEM2) envolvidos na regulação da proliferação celular (Marx, 2005). As manifestações clínicas associadas às NEMs são decorrentes, sobretudo do excesso de hormônios produzidos pelos tumores ou pela massa tumoral. Por outro lado, há os tumores não-produtores que podem benignos ou malignos e frequentemente somente levam a sinais/sintomas devido aos efeitos secundários de sua expansão tumoral.

Clínicas associadas às neoplasias endócrinas múltiplas são decorrentes sobretudo do excesso de hormônios produzidos pelos tumores ou pela massa tumoral. 
Tabela 1: Caracterização Clínica e genética das Neoplasias Endócrinas Múltiplas

\begin{tabular}{|c|c|c|}
\hline Síndrome & $\begin{array}{l}\text { Principais Manifestações } \\
\text { Clínicas }\end{array}$ & $\begin{array}{l}\text { Anormalidade genética } \\
\text { Gene/lócus }\end{array}$ \\
\hline NEM1 & $\begin{array}{l}\text { Adenomas hipofisários } \\
\text { Hiperparatireoidismo primário } \\
\text { Tumores das ilhotas } \\
\text { pancreáticas/duodeno endócrino } \\
\text { Tumores do córtex adrenal } \\
\text { Angiofibroma cutâneo } \\
\text { Lipomas }\end{array}$ & $\begin{array}{l}\text { Mutação inativadora do } \\
\text { gene MEN1 (11q13) que } \\
\text { codifica a proteína } \\
\text { MENIN }\end{array}$ \\
\hline NEM2 & $\begin{array}{l}\text { Carcinoma Medular de Tiróide } \\
\text { Feocromocitoma } \\
\text { Hiperparatireoidismo primário }\end{array}$ & $\begin{array}{l}\text { Mutação ativadora do } \\
\text { proto-oncogene } R E T \text { que } \\
\text { codifica o receptor RET }\end{array}$ \\
\hline $\begin{array}{l}\text { Neurofibromatose } \\
\text { tipo } 1\end{array}$ & $\begin{array}{l}\text { Tumores endócrinos associados: } \\
\text { Feocromocitoma } \\
\text { Carcinoma medular de tiróide } \\
\text { Hiperparatiroidismo primário } \\
\text { Tumor carcinoide produtor de } \\
\text { somatostatina }\end{array}$ & $\begin{array}{l}\text { Mutação inativadora do } \\
\text { gene } N F-1(17 q 11.2) \text { que } \\
\text { codifica a proteína } \\
\text { neurofibromin }\end{array}$ \\
\hline Von Hippel-Lindau & $\begin{array}{l}\text { Feocromocitoma } \\
\text { Tumores das ilhotas pancreáticas } \\
\text { Hemangioblastoma do SNC } \\
\text { Angiomas da retina } \\
\text { Hipernefromas } \\
\text { Cistos Viscerais } \\
\text { Neurofibromas }\end{array}$ & $\begin{array}{l}\text { Mutação inativadora do } \\
\text { gene } V H L(3 p 25) \text { que } \\
\text { codifica a proteína } \\
\text { elongina }\end{array}$ \\
\hline $\begin{array}{l}\text { Complexo de } \\
\text { Carney }\end{array}$ & $\begin{array}{l}\text { Pigmentação cutânea puntiforme } \\
\text { Mixoma Cardíaco } \\
\text { Mixoma cutâneo } \\
\text { Doença adrenocortical } \\
\text { pigmentar nodular primária } \\
\text { Tumor de células de Sertoli } \\
\text { Acromegalia } \\
\text { Schawanoma }\end{array}$ & $\begin{array}{l}\text { Mutação inativadora do } \\
\text { gene PRKAR1A (17q22- } \\
\text { 24) identificada em } \\
\text { algumas famílias }\end{array}$ \\
\hline
\end{tabular}




\subsection{Neoplasia Endócrina Múltipla Tipo 1}

\subsubsection{Conceito}

A NEM1 é uma doença rara de ocorrência usualmente familiar, mas também pode se apresentar eventualmente como esporádica e é caracterizada por sua complexidade clínica. As principais glândulas associadas a essa síndrome são: paratireoides, hipófise e pâncreas endócrino/duodeno (Figura 1). Seu diagnóstico é feito pelo reconhecimento clínico de tumores em pelo menos duas das três glândulas endócrinas-alvos nos casos-índice. Entretanto, atualmente mais de 20 diferentes neoplasias foram associadas à NEM1, incluindo neoplasias benignas e malignas, endócrinas e não-endócrinas, com presença de tumores funcionantes e nãofuncionantes (Tabela 2) (Marx, 2005). Usualmente, na segunda década de vida dos pacientes geneticamente predispostos (portadores de mutação germinativa no gene MEN1), há desenvolvimento de tumores benignos, enquanto a partir da $4^{a}$ década de vida, há um aumento significativo de ocorrência de tumores malignos, que podem apresentar alta agressividade levando à morte cerca de um terço (33\%) destes pacientes (Wilkinson, 1993; Geerdink, 2003).

Estima-se que a incidência na população da NEM1 varia de 0,01 a 2,5 por 1.000. As manifestações clínicas da doença estão relacionadas com o órgão afetado e podem incluir efeitos de massa devido ao tamanho do tumor, hipersecreção hormonal e malignidade.

A NEM1 familiar tem um padrão de herança autossômica dominante com elevada penetrância e expressividade clínica variável. O diagnóstico desta síndrome pode ser: clínico e/ou genético. Para a realização do diagnóstico clinico é necessário haver a identificação de um caso índice com NEM1 (presença de pelo menos duas das três glândulas alvo-principais envolvidas) e de um parente de primeiro grau com tumor em pelo menos 
uma dessas três glândulas endócrinas alvos principais na NEM1 (Lourenço et al, 2002); e genético, pela identificação de mutação germinativa no principal gene responsável pela doença, o gene supressor de tumor MEN1 (Brandi, 2001; Marx, 2005). A ausência de histórico familiar, é sugestiva de NEM1 esporádico, que se caracteriza pela associação coincidental de dois tumores NEM1-relacionados, sem a presença de mutação germinativa no gene MEN1. Além disso cerca de $10 \%$ dos casos resultam de mutação de novo. Existem algumas variantes clínicas conhecidas na NEM1, como a variante Burin, que se apresenta frequências elevadas de prolactinomas, carcinoides e hiperparatiroidismo primário (HPT), mas frequências bastante baixas de tumores pancreáticos (Olufemi et al, 1998).

A NEM1 não apresenta regiões hot-spots no gene MEN1, sendo assim as mutações germinativas encontram-se espalhadas por toda a região codificadora do gene MEN1.

Existem alguns pontos que ainda não foram adequadamente esclarecidos tais como a susceptibilidade diferencial dos pacientes aos vários tumores relacionados à NEM1, devido à grande variabilidade fenotípica intra e interfamilial em casos portadores de uma mesma mutação germinativa específica. 
Tabela 2: Frequência de tumores endócrinos e não-endócrinos na NEM1

\section{TUMORES ENDÓCRINOS}

Adenoma de paratireóide (>90\%)

Tumores da hipófise anterior (20-40\%):

Prolactinoma $(70 \%)$

Cossecretores (10\%)

Somatotropinoma (9\%)

ACTHoma (4\%)

TSHoma (raro)

Não-funcionante (20\%)

Tumores entero-pancreáticos (35\%-70\%)

Gastrinoma (40\%-75\%) *

Não-funcionante, incluindo PP (20\%)*

Outros: Glucagonoma*, Vipoma* Somatostatinoma*, etc (2\%)

Carcinoides :

Tímico $(2 \%)^{*}$

Brônquico (2\%)

Tumor gástrico (10\%)

Tumores Cortiço adrenais não funcionantes (25\%)

\section{TUMORES NÃO-ENDÓCRINOS}

Lipoma (30\%)

Leiomioma (10\%)

Angiofibroma (85\%)

Colagenoma $(70 \%)$

Ependimoma (1\%)

Meningeoma (5\%) 


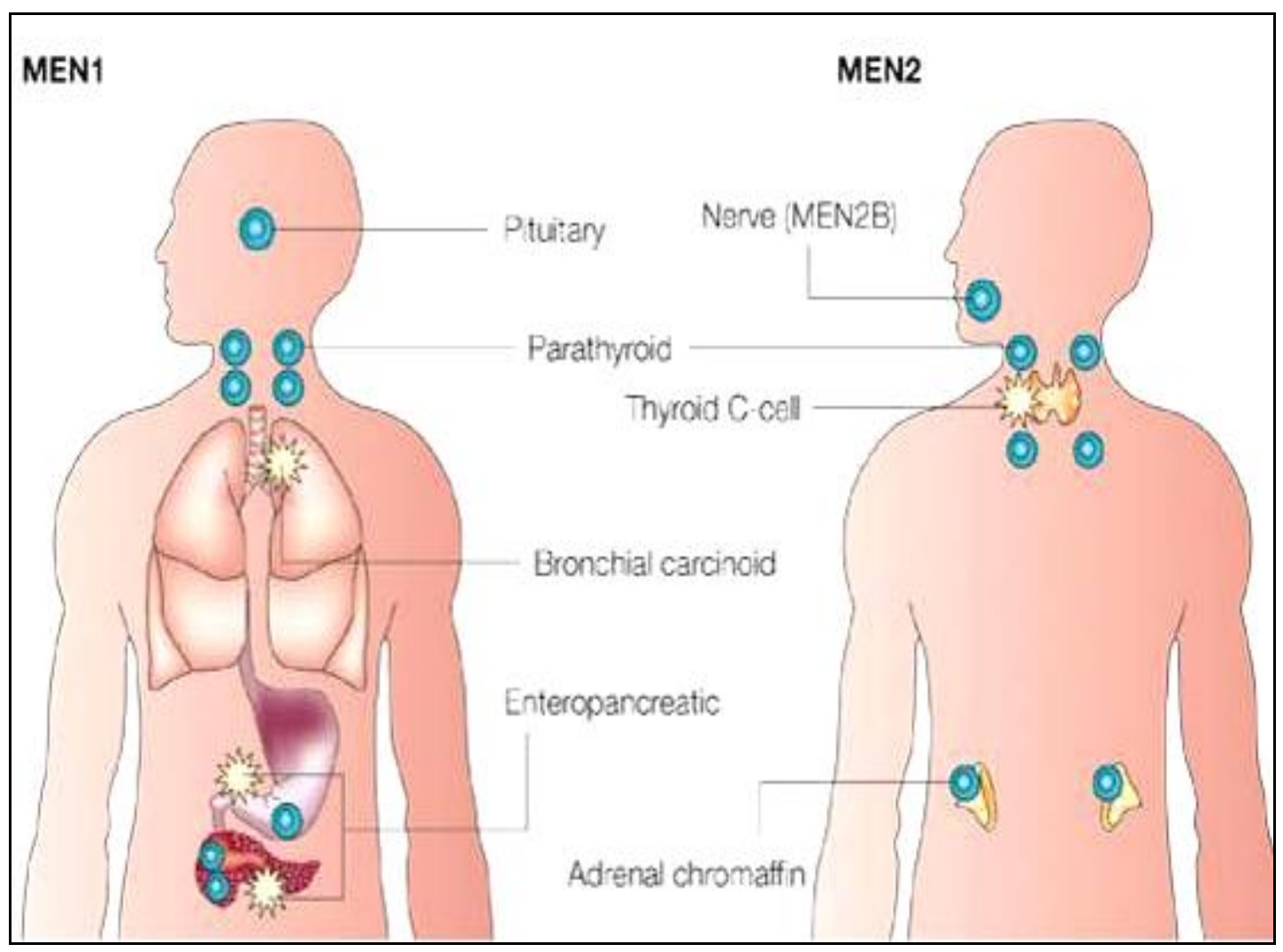

* Potencial maligno superiores a $25 \%$

Figura 1: Ilustração das principais glândulas afetadas na NEM1 e NEM2 (Marx 2005)

\subsection{Aspectos clínicos da NEM1}

\subsubsection{Hiperparatireoidismo}

O hiperparatireoidismo primário (HPT) é a manifestação clínica mais frequente nos pacientes NEM1, observado em $80 \%$ a $100 \%$ dos casos (Brandi, 2001; Verges 2002, Schussheim et al, 2001). Esse distúrbio resulta da hipersecreção do hormônio das paratireóides, paratohormônio (PTH). Há relatos de casos com HPT/NEM1 em idades precoces, porém em geral a manifestação ocorre ao redor dos 20 anos (Metz et al,1994, Burgess et al,1999). 
Os achados clínicos mais frequentes do HPT relacionado à NEM1 são nefrolitíase, fraqueza muscular, artralgias, alterações do estado mental como depressão, dor óssea, anorexia, constipação e dor abdominal. A osteoporose diagnosticada em idade precoce é uma doença freqüente no HPT/NEM1 e se correlaciona com um aumento da probabilidade de fraturas (Bone, 1990; Metz et al, 1994).

Estima-se que cerca de $20 \%$ dos pacientes com hiperplasia primária das paratireóides estejam relacionados às NEMs (Delellis, 1995). O diagnóstico de HPT é usualmente realizado por dosagem cálcio sérico que se encontra elevado, associada a hipercalciúria e a níveis séricos de PTH elevados, enquanto os níveis de fosfato sérico estão baixos.

A lesão histológica das paratireóides mais frequentemente observadas na NEM1 é a hiperplasia difusa ou nodular e mais tardiamente mudanças adenomatosas podem também ser encontradas (Gagel, 1998).

O quadro clínico do HPT/NEM1 em geral é de grau leve. Ocasionalmente, o HPT/NEM1 pode evoluir de forma mais grave (Bone et al,1990; Mallette et al, 1994).

O tratamento para o HPT/NEM1 é geralmente cirúrgico, entretanto ainda não existe um consenso claro sobre o melhor momento para a cirurgia. Nesse sentido, os critérios utilizados para o manejo clínico-cirúrgico dos casos HPT/NEM1 são os mesmos estabelecidos no último consenso sobre HPT/esporádico (Bilezikian, 2002).

Há dois procedimentos cirúrgicos para o tratamento do HPT/NEM1:

a) paratireoidectomia subtotal;

b) paratireoidectomia total seguida de enxerto de uma tecido paratireoidiano no antebraço não dominante.

Levando-se em conta o acometimento multiglandular (Figura 2) e as altas taxas de recidiva em casos NEM1, o tratamento cirúrgico indicado é mais extenso que a adenomectomia, usualmente realizada no HPT 
esporádico. Dessa forma, a abordagem cirúrgica que vem sendo utilizada com sucesso no Hospital das Clínicas da FMUSP-SP em casos com HPT/NEM1 é a paratireoidectomia total seguida por implante de tecido fragmentado paratireoideano no antebraço não-dominante (Montenegro, 2005).

A monitoração da qualidade do implante é realizada por meio de dosagens de PTHe e cálcio. Uma desvantagem da paratireoidectomia total é a ocorrência de hipoparatireoidismo pós cirúrgico uma vez que o implante começa usualmente a funcionar entre 6 e 12 semanas após a cirurgia.

Os principais objetivos do tratamento no HPT/NEM1 são:

a) obter e manter níveis/ concentração séricos normais de PTH e cálcio;

b) evitar a hipocalcemia;

c) excluir o estímulo hipercalcêmico crônico sobre o gastrinoma e excluir o estímulo deletério do PTH sobre a massa óssea e prevenir complicações renais do HPT (Carling et al, 2005).

HPT esporádico

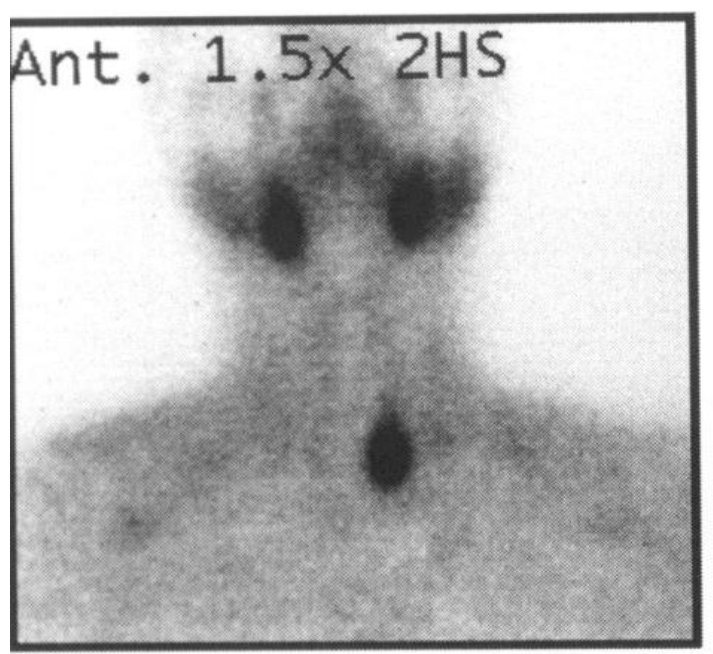

Figura 2: Cintilografia evidenciando o acometimento uniglandular no HPT esporádico e o multiglandular em casos com NEM1
HPT/NEM1

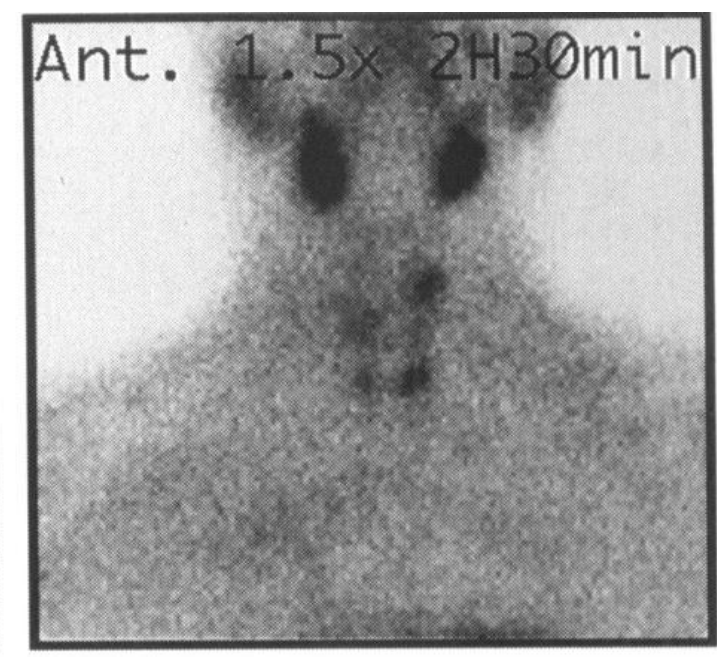




\subsubsection{Tumores Entero-Pancreáticos na NEM1}

Os tumores entero-pancreáticos (TEPs) ocorrem em $30-80 \%$ dos pacientes com NEM1, com sua penetrância variável dependendo da população estudada (Trump, 1996; Marx, 2005; Grama, 1992).

\subsubsection{Gastrinoma}

Os gastrinomas são tumores secretores de gastrina, sendo encontrados em $40-75 \%$ dos casos. Esses tumores associados à NEM1 são predominantemente duodenais, múltiplos e com baixas taxas de cura.

O tratamento preconizado para o gastrinoma relacionado à NEM1, consiste na administração de bloqueadores de bomba de prótons para o controle da hipersecreção gástrica, seguido de tratamento cirúrgico (Marx et al, 1998), sendo o objetivo a redução de metástases hepáticas uma vez que a cura total é dificilmente alcançada. Mais recentemente, tem-se preconizado cirurgias mais precoces em casos com tumores pancreáticoduodenais com aproximadamente $1 \mathrm{~cm}$ (Ackerstrom, 2012).

\subsubsection{Insulinoma}

O insulinoma é um tumor originário das células beta das ilhotas pancreáticas, sendo o tumor de células das ilhotas mais frequente na população geral (Delcore et al, 1994). Na NEM1 é o segundo tumor pancreático mais prevalente, após o gastrinoma.

A verdadeira incidência de insulinoma é desconhecida e estima-se que seja de 4 casos por 1 milhão na população geral com predominância igual em ambos os sexos (Delcore et al, 1994). A maioria dos tumores esporádicos é benigna (90\%). Somente $10 \%$ a $15 \%$ dos insulinomas são malignos, com invasão capsular e vascular. 
Os insulinomas na NEM1 diferem dos esporádicos por se apresentarem mais precocemente, na $3^{\circ}$ e $4^{\circ}$ década (os esporádicos geralmente aparecem na $5^{\circ}$ década); são geralmente múltiplos; têm maior incidência de malignidade; ausência de ocorrência de insulinoma/NEM1 extrapancreático e por apresentarem maiores taxas de recorrência póscirúrgica.

O diagnóstico é realizado através de dosagens das concentrações de insulina plasmática elevadas e níveis baixos de glicose plasmática, não havendo diferenças no diagnóstico laboratorial entre 0 insulinoma esporádico e insulinoma associado à NEM1.

O tratamento do insulinoma é cirúrgico, basicamente com o objetivo de preservar as funções endócrinas e exócrinas pancreáticas e o alívio de sintomas hipoglicêmicos. Assim, a pancreotectomia parcial é recomendada para os casos esporádicos, enquanto a pancreatectomia subtotal (ou mesmo total) é preconizada para os casos com NEM1 (Brandi, 2001; Metz, 1994).

\subsubsection{Adenomas hipofisários}

Os tumores hipofisários relacionados à NEM1 são usualmente detectados entre 17 e 65 anos de idade, tal como nos esporádicos (13 a 75 anos). Em geral, menos de 5\% dos adenomas hipofisários e 2 a 3\% dos prolactinomas estão relacionados à NEM1 (Corbetta, 1997).

A penetrância de tumores hipofisários na NEM1 (HIP/NEM1) é bastante variável, oscilando entre 18-40\% (Verges, 2002; Benson, 1987; Samaan, 1989). Aproximadamente $80 \%$ dos HIP/NEM1 são macroadenomas, em contraste com $42 \%$ de macroadenomas encontrados nos casos com HIP esporádicos (HIPe) (Verges, 2002). Outra característica específica dos HIP/NEM1 é se apresentarem como multicêntricos e plurihormonais (Verges, 2002).

O diagnóstico clínico e laboratorial segue os mesmos padrões tanto para os adenomas hipofisários associados à NEM1 como para os adenomas 
hipofisários esporádicos. Dos diversos subtipos de tumores hipofisários, os mais frequentemente associados à NEM1 são os prolactinomas, adenomas hipofisários secretores de $\mathrm{GH}$, adenomas hipofisários secretores de ACTH e adenomas na funcionantes nas seguintes proporções $76 \%, 5 \%, 6 \%$ e $20 \%$ (Metz et al, 1994; Corbetta et al, 1997).

O tratamento dos adenomas hipofisários associados NEM1 não difere do aplicado em adenomas hipofisários esporádicos.

\subsubsection{Outros tumores na NEM1}

Além dos tumores clássicos, cerca de 20 tumores endócrinos e nãoendócrinos foram identificados em pacientes com NEM1 e relacionados a essa síndrome. (Marx, 2005). Dentre eles podemos citar: tumor carcinoide tímico e brônquico, tumores adrenais e tumores carcinoides gástricos. Devido à ampla variabilidade de tumores e manifestações clínicas nesta síndrome, a NEM1 é hoje considerada uma doença complexa e multissistêmica (Marx, 2005).

\subsection{Consenso sobre NEMs / 2001}

Brandi et al. (2001) relataram resultados do Consenso sobre NEM1 e NEM2, no qual foram propostos os critérios básicos para o diagnóstico e as condutas terapêuticas para essas entidades. Quanto à NEM1, neste Consenso propõe-se:

a) seguimento anual bioquímico associado a seguimento com exames de imagem a cada três anos;

b) paratireoidectomia total ou subtotal e timectomia preventiva; 
c) a cirurgia deve ser o tratamento de escolha nos casos de hipoglicemia devido a insulinoma;

d) há controvérsias quanto à indicação de tratamento cirúrgico dos gastrinomas;

e) o diagnóstico gênico na NEM1 é importante, mas não orienta diretamente a conduta cirúrgica.

\subsection{Critérios para rastreamento genético NEM1}

Segundo os critérios do Consenso sobre NEMs (Brandi, 2001), há recomendação para a análise de mutação no gene MEN1 dos seguintes casos:

a) pacientes-índices com NEM1 (>2 tumores NEM1-relacionados);

b) parentes de primeiro grau de casos-índices com NEM1; e

c) casos que apresentem tumores múltiplos de paratireóides antes de 30 anos de idade, ou tumores neuro-endócrinos pancreáticos múltiplos em qualquer idade.

\subsection{Mortalidade na NEM1}

Os tumores carcinóides e gastrinomas são as principais causas de morte em pacientes com NEM1 (Teh, 1997 e 1998). Mais de 90\% dos tumores carcinóides associados à NEM1 (geralmente afetando o timo) são malignos (Teh, 1997 e 1998; Gibril, 2003). Entretanto, estes tumores são relativamente raros na NEM1, com penetrância de aproximadamente $10 \%$. 
Por outro lado, apesar de os gastrinomas terem menor prevalência de malignidade comparada a dos carcinóides (60\%; Kouvaraki, 2006), eles podem estar presentes em até $75 \%$ dos casos com NEM1, dependendo da população analisada. Assim, o gastrinoma é considerado o principal tumor associado à mortalidade na NEM1 (Kouvaraki, 2006).

A ocorrência de metástases nesta síndrome é associada à redução significativa da idade média de sobrevida em casos com NEM1 (55,4 anos para homens e 46,8 anos para mulheres), quando comparada à expectativa de vida da população não afetada (> 70 anos; Geerdink, 2003).

\subsection{Aspectos Moleculares}

\subsubsection{Clonagem do gene MEN1}

As neoplasias ocorrem em decorrência da ativação de protooncogene e/ou então pela inativação de genes supressores de tumor (Hanahan D, 2000). Os primeiros transcrevem fatores que induzem 0 crescimento celular e mitose, enquanto os segundos transcrevem proteínas que regulam e controlam esses processos (chamadas proteínas supressoras de tumor) (Marx, 2005).

A NEM1 é uma doença autossômica dominante causada pela inativação do gene supressor de tumor MEN1 (U93236, Genbank). A localização do gene MEN1 foi estabelecida por análise de perda de heterozigose ( $\mathrm{LOH})$ em tumores entero-pancreáticos de pacientes com NEM1 (Larsson, 1988). O material genético de insulinomas foi estudado através de sondas de DNA que abrangiam todos os cromossomos humanos. Esse estudo revelou a ausência de bandas do cromossomo 11 (Larsson, 1988). Estudos de ligação subseqüentes reduziram para 2 centiMorgan ( 2 
Megabases de DNA) a região cromossômica envolvida (Lubensky, 1996; Bale, 1989; Janson, 1991; Courseaux, 1996; Nakamura, 1989; Thakker, 1989).

Aproximadamente 10 anos após o trabalho original de Larsson et al (1998), estudos utilizando técnicas de clonagem posicional isolaram o gene MEN1 no braço longo do cromossomo 11, região 1, sub-região 3 (11q13) (Lemmens, 1997; Chandrasekharappa, 1997). Análises desses gene MEN1 em pacientes com NEM1 familiar e esporádica documentaram mutações germinativas e somáticas, confirmando sua associação com a doença. Os resultados observados de mutações germinativas associadas à LOH em tumores NEM1 fundamentam a hipótese que o MEN1 é um gene supressor de tumor (Knudson, 1971).

\subsubsection{Proteína MENIN, codificada pelo gene MEN1}

O gene MEN1 possui 9,2 Kb e consiste de 10 éxons. Codifica uma proteína de 610 aminoácidos chamada MENIN, mutações encontradas neste gene são em éxons e íntrons. Análises das seqüências clonadas mostraram não haver motivos repetitivos nessa proteína, porém 28 pontos de fosforilação foram encontrados; dentre eles 2 foram identificados em mutações causadoras da doença. A MENIN é uma proteína muito diferente de todas outras proteínas já clonadas em humanos até o momento. Por esse motivo, existe significativa dificuldade em traçar paralelos para obtenção de informações sobre a função dessa proteína. O que se sabe a respeito de sua função é oriundo de estudos in vitro (Marx SJ, 2005).

A MENIN é expressa de forma variável tanto em tecidos endócrinos, como em tecidos não-endócrinos. Em adultos, a MENIN parece ser expressa de forma mais intensa em certos tecidos como o endométrio uterino (Ikeo, 2000).

Ha evidências que a proteína MENIN se localiza no núcleo celular, porém pode também ser encontrada no citoplasma durante a divisão celular 
HEK 293, (Huang, 1999), cuja função exata ainda não é totalmente conhecida. A MENIN interfere no sistema de reparo de DNA. Tratamentos químicos em células de pacientes com NEM1 apresentaram maiores taxas de alterações cromossômicas espontâneas e mitoses com divisões centroméricas prematuras (Scappaticci, 1991). Outro estudo demonstrou que células que superexpressavam MENIN apresentavam um atraso em seu ciclo celular, quando expostas a tratamentos químicos (Ikeo, 2000). A maneira como a proteína MENIN estaria agindo no controle do ciclo celular e no reparo de DNA ainda não foi esclarecido.

O mecanismo que regula a proliferação celular sob ação da MENIN ainda não foi completamente estabelecido, entretanto deve estar ligado às diversas proteínas com as quais a MENIN interage. Recentemente, dados da literatura demonstraram que a MENIN interage com o fator de transcrição junD, participando da proliferação celular. Três domínios da proteína MENIN são cruciais para a interação do complexo MENIN-JunD, os 40 aminoácidos da região $\mathrm{N}$-terminal e duas da região central, nas posições respectivamente, 139 a 142 e 323 a 428 (Marx, 2005).

Estudos utilizando fungos duplo-híbridos mostraram ligação e acoplamento entre MENIN e Jun-D. A proteína Jun-D dimeriza com outras proteínas da sua família ou com proteínas da família Fos para formar o fator de transcrição AP-1 (Agarwal, 1999). A MENIN suprime a atividade de transcrição dependente do junD na célula intacta, embora não se saiba como contribui para sua atividade reguladora do crescimento celular. A MENIN também interage com o SMAD3, um fator de transcrição envolvido na via de sinalização do TGBF-B, entre outras proteínas (Greenspan, 2006) (Figura 3). Quando ocorre a mutação, leva a mudanças significativas na conformação e de sua função ocorrendo a inativação da proteína MENIN, levando a super transcrição e consequentemente o desenvolvimentos de neoplasias. (Figura 4) 


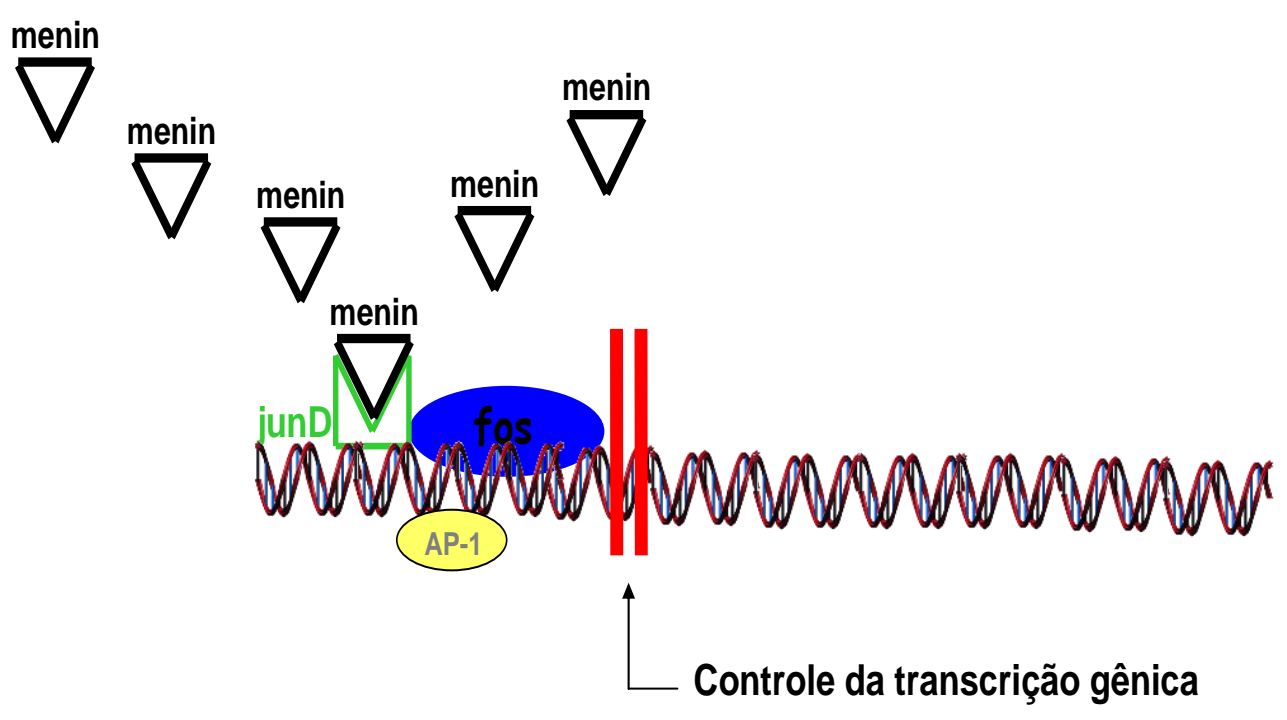

Figura 3: Ação da proteína $M E N I N$ integra associada ao fator de transcrição JunD, a MENIN revertendo o efeito da JunD na indução ao crescimento e ao inicio do ciclo celular
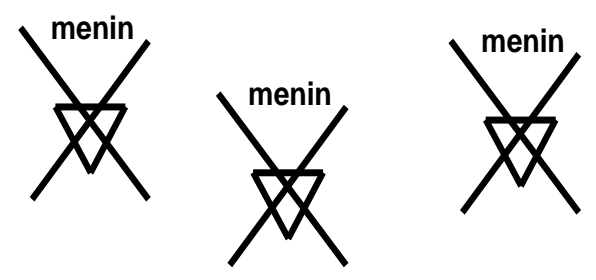

Proteína supressora de Tumor

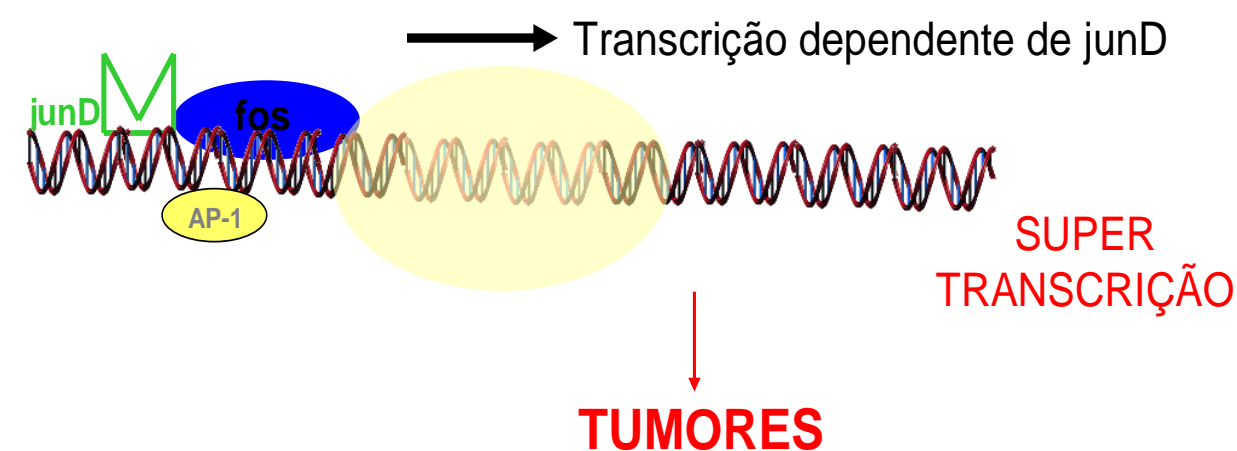

MEN-1

Agarwal, 2002

Figura 4: Ação da MENIN em indivíduos com NEM1 (Marx, 2005) 
Recentemente, interações entre a MENIN e outras proteínas nucleares foram relatadas. Interações com Pem, Nm23 e os genes homeoboxes hPEPP1 e hPEPP2 foram descritas (Balogh, 2006). Interações da MENIN com RPA2 (uma proteína necessária na replicação, recombinação e reparo de DNA também foram verificadas. Foi mostrado também que a MENIN interage diretamente em promotores de genes, regulando sua expressão (Marx, 2005). Essas novas interações da MENIN com outras proteínas nucleares poderão trazer novos esclarecimentos sobre o seu papel celular (revisto por Marx, 2005 e Balogh, 2006) (Figura 5).

\section{Funções e interações da proteína MENIN}

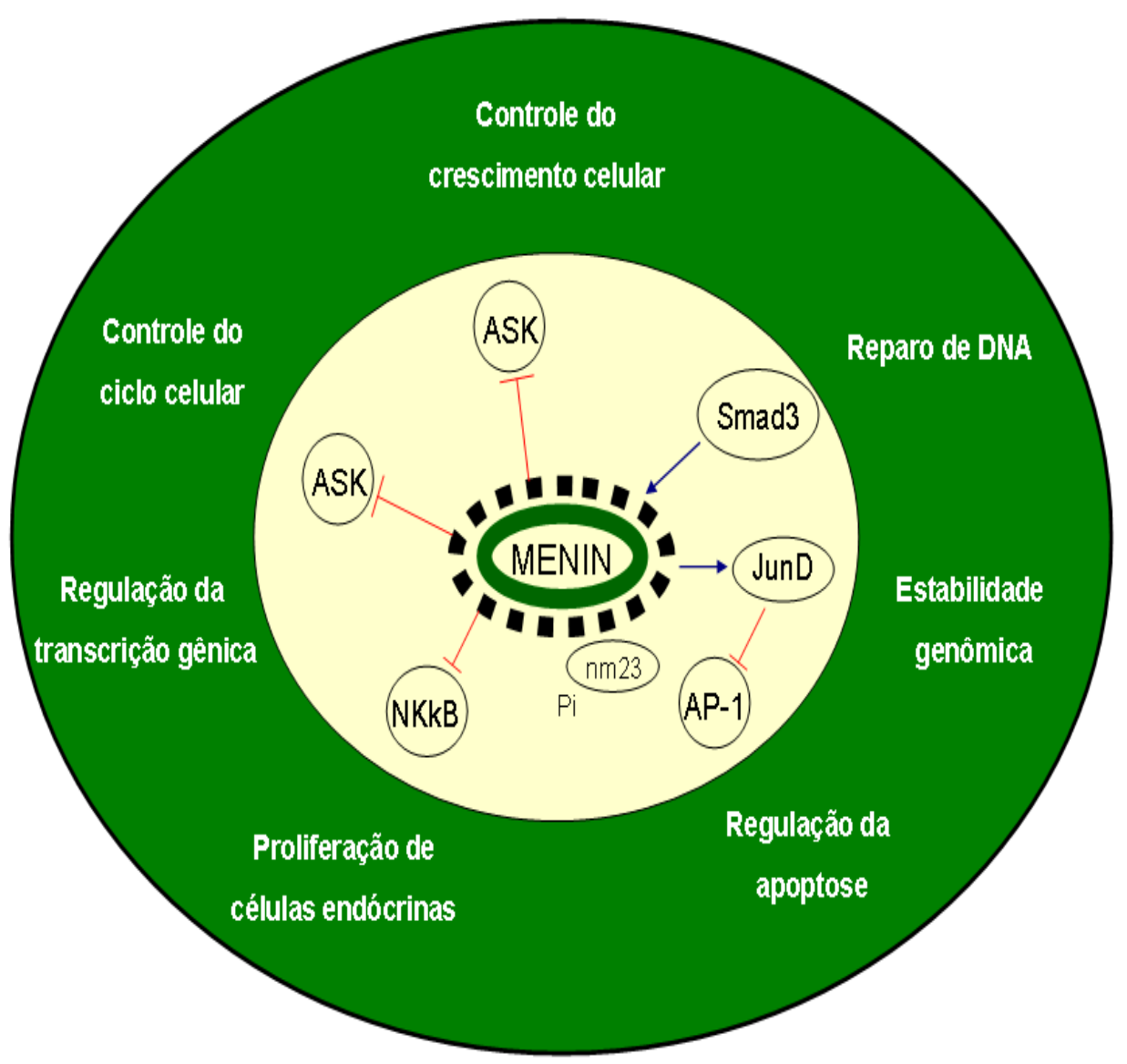

Figura 5: O produto do gene MEN1 é a proteína supressora de tumor chamada MENIN. Por exercer funções essenciais, como controle do ciclo e do crescimento celular, regulação da transcrição gênica através de interações com a JunD (adaptado de Balog, 2006) 
Atualmente, a MENIN esta envolvida em processos celulares essenciais, como:
a) controle do crescimento celular;
b) ciclo celular;
c) regulação da transcrição gênica;
d) regulação da apoptose;
d) estabilidade genômica;
e) reparo de DNA (Balogh, 2006).

\subsection{Modelo animal da NEM1}

Um modelo animal que se mostrou interessante para o estudo da NEM1 foi o camundongo com inativação do gene MEN1 (knock-out). Os camundongos duplo homozigotos apresentam um fenótipo embriológico letal entre os dias 11,5 e 12,5. Já os heterozigotos, apresentam tumores de pâncreas (insulinomas), paratireóide (adenomas) e hipófise (prolactinomas), as quais são características bastante semelhantes às encontradas em pacientes com NEM1; exceção feita à ausência de gastrinomas no modelo animal (Crabtree, 2001 e 2003).

O estudo de linhagens de camundongos provenientes do cruzamento de animais MEN1 -/- e JunD -/- proporcionou um melhor entendimento sobre a interação entre essas duas proteínas. A JunD é um fator de transcrição da família de proteínas ativadoras - 1 (AP-1) e está envolvida na indução da transcrição gênica e da mitose (Agarwal, 1999). Estudos funcionais 
mostraram que a MENIN pode ser encontrada associada à JunD, formando um complexo MENIN/JunD. Quando associadas, a MENIN reverte o efeito da JunD na indução ao crescimento e ao início do ciclo celular (Yazgan, 2001). Foi mostrado que quando isolada, a JunD tem características de proteína promotora de crescimento, entretanto quando associada à MENIN, passa a ter características de supressora de crescimento (Agarwal, 1999). Assim, ficou demonstrado que a proteína MENIN exerce importante função antitumorigênica através de sua associação com a JunD.

\subsection{Tumorigênese}

Sabemos que a tumorigênese é um processo bastante complexo e que freqüentemente envolve inativação de diversos genes supressores de tumor e ativação de proto-oncogenes, como podemos ver nos modelos de tumorigênese de diversos cânceres, como o câncer de cólon e mama, assim como de tumores endócrinos como os da córtex da adrenal e hipófise, por exemplo, (Figura 6). 


\section{Sinalização}

Desregulação ciclo celular( Rb,p16,p18,p27)

Regulação MENIN, instabilidade genômica

\section{superexpressão do oncogene PTTG e outros}

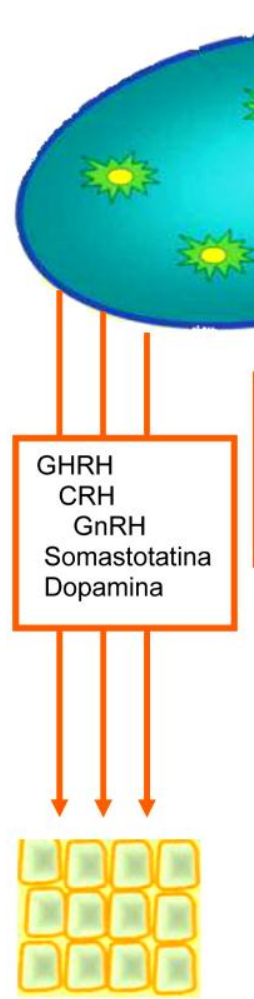

Hipófise normal monoclonalidade alterações genômicas (aneuploidia) p16, $\mathrm{Rb}$, metilação e menin perdas, AIP perdas, mutação p27 expressão PTTG
Proliferação monoclonal, alterações genômicas e metilação PTTG e outros superexpressão oncogenes (N-RAS) angiogenese
Desregulação do GHRH somastotatina e / ou dopamina e / ou outros Fatores aneuploidia, alteração genética, a metilação

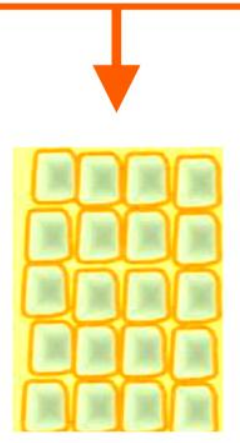

Hiperplasia Benigna

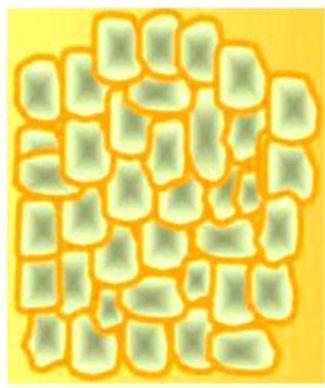

Adenoma

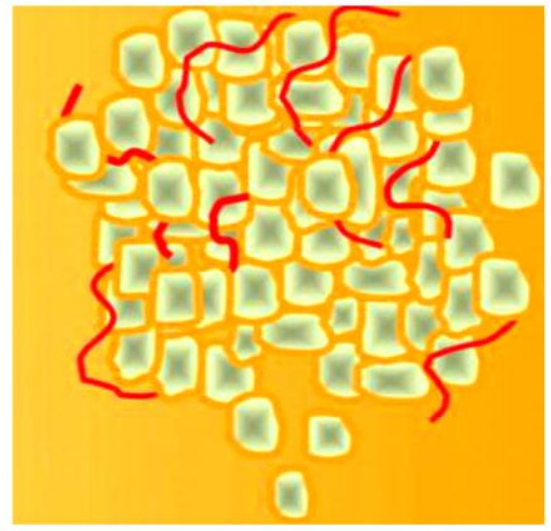

Adenoma Invasivo

Figura 6: Modelo multistep da tumorigênese em tumores Hipofisários. Notase a ocorrência de diversos eventos genéticos que controlam a evolução de uma hipófise normal até a formação de um adenoma invasivo. (adptada de Boikos \& Stratakis 2007)

Quanto à NEM1, apesar dos achados genéticos, nosso conhecimento sobre a gênese e progressão dos tumores dessa síndrome se limita à perda somática do alelo selvagem (11q13-LOH), como descrito a seguir. 
De acordo com a hipótese de Knudson, o desenvolvimento de tumores em pacientes com NEM1 familial ocorre por uma seqüência de dois eventos mutacionais, sendo que o primeiro evento refere-se a uma mutação herdada (mutação germinativa). Assim, todas as células do corpo dos portadores possuem um alelo desse gene inativado. $O$ segundo evento mutacional (deleção mutação somática, metilação) ocorre geralmente a partir dos 20 anos de idade, nos tecidos afetados pela doença (glândulas paratireóides, hipófise e pâncreas endócrino). Assim, as glândulas dos pacientes com NEM1 acumulam uma mutação em cada alelo, levando à inativação completa do gene MEN1 e conseqüentemente inativação da MENIN (Figura 7). O descontrole do ciclo celular causada pela ausência da proteína MENIN nas células dessas glândulas leva ao desenvolvimento de hiperplasias, adenomas e carcinoides, etc., relacionados à NEM1 (Balogh, 2006).

Esse processo de tumorigênese, baseado em dois eventos mutacionais, foi primeiramente proposto por Knudson para o retinoblastoma (Knudson 1971). Segundo esse processo, o indivíduo que herdar uma mutação germinativa no gene MEN1 tem, desde o nascimento, predisposição aos tumores NEM1-relacionados. Assim, indivíduos com NEM1 geralmente apresentam tumores em idades mais precoces do que nos casos esporádicos, cujos tumores desenvolvem de forma aleatória e somente após a ocorrência de duas mutações somáticas (Marx, 2005). 


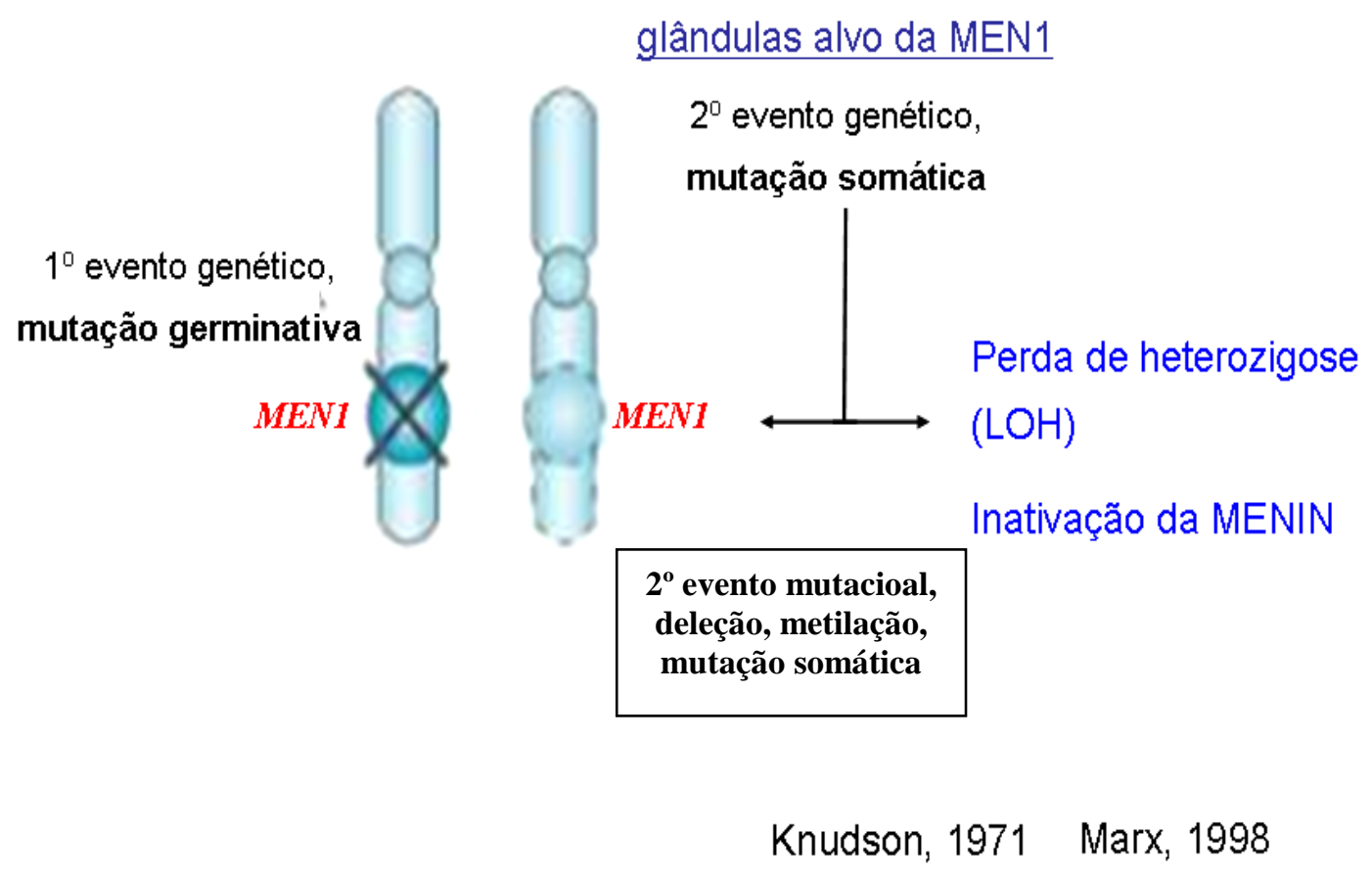

Figura 7: Tumorigênese na NEM1. Modelo de dois eventos mutacionais para genes supressores de tumor, como o MEN1 (Knudson, 1971; Agarwal, 1999)

\subsection{Estudo de perda de heterozigose em tumores de pacientes com NEM1}

Análises de perda de heterozigose (LOH) do locus do gene MEN1 (11q13) revelaram que o alelo normal do gene MEN1 é inativado (segundo evento mutacional, somático) em tumores de pacientes com NEM1. Esses estudos que mostraram a inativação bialélica de gene supressor de tumor (Larsson, 1988) vêm ampliando o painel de tumores relacionados à NEM1 e, assim, podem gerar dados que informam ao clínico sobre outros possíveis tumores que devem ser rastreados nos exames clínicos desses pacientes, proporcionando assim uma melhor prevenção e tratamento desses tumores. 
Estudos somáticos também podem revelar novos genes que eventualmente podem estar inativados e, assim, podem participar do processo multistep da tumorigênese da NEM1, aumentando nosso conhecimento sobre as vias de supressores de tumor que estão envolvidas na patogênese dessa doença.

\subsection{Evidências do envolvimento de outro(s) gene(s) na NEM1}

Apesar do MEN1 ser o principal gene responsável pela NEM1, há ausência de mutações em 10-30\% dos casos hereditários, o que geralmente é atribuída à:

a) variação de sensibilidade dos métodos laboratoriais empregados;

b) presença de mutações fora da região codificadora do gene; $\mathrm{e}$

c) presença de grandes deleções, que não são identificados via PCR (Cavaco, 2002).

Entretanto, mais recentemente se tem sugerido que a ausência de mutações no gene MEN1 em casos com NEM1, ao invés de ser causada por limitações técnicas para detecção de mutações, seria causada por uma heterogeneidade genética nessa doença. Um extenso estudo analisou (através das técnicas de MPLA / MRC Holland e PCR de longo alcance) a presença de eventuais grandes deleções e mutações na região promotora de 101 casos com diagnóstico clínico de NEM1 sem mutação no gene MEN1; e apenas uma grande deleção foi encontrada (Vaidya, 2007). Nesse artigo, os autores sugerem que a presença de um evento germinativo em outros genes que não o MEN1 estaria envolvido na determinação do fenótipo da NEM1 nesses 100/101 casos restantes. (Vaidya, 2007). 


\subsection{Novos genes recentemente associados à NEM1 e a doenças NEM1-relacionadas}

Seguindo a indicação da provável existência de genes ainda não identificados associados à NEM1, estudos recentes rastrearam mutações em novos genes candidatos e confirmaram a hipótese da NEM1 ser uma doença com heterogeneidade genética. Neste contexto, trata-se de uma hipótese plausível pensar que, outras vias (além da supressora de tumor MEN1) estariam influenciando a tumorigênese na NEM1, desta forma incluímos neste estudo análise somática dos genes CDKN1B e AIP.

\subsubsection{Gene p27(Kip1)/CDKN1B}

Nas décadas de 70 e 80, o gene p27(Kip1)/CDKN1B foi intensamente estudado em diversos tipos de tumores humanos. Um extenso estudo analisou 432 tumores: leucemia, sarcomas, próstata, testicular, gástrico e endometrial, e nenhuma mutação patogênica foi identificada, verificando que mutações no gene p27(Kip1)/CDKN1B são muito raras (Kawamata, 1995). Esse resultado negativo levou a uma redução dos estudos de análise molecular de p27(Kip1)/CDKN1B, entretanto estudos de expressão mostraram perda de p27 associada a pior prognóstico.

Em relação aos estudos de expressão de p27 em 203, carcinomas hepatocelular e 149 carcinomas coloretal por hibridização in situ (cDNA) e expressão protéica por imunohistoquímica, verificou-se a redução ou ausência de expressão de p27. Tumores com baixa expressão de p27 apresentam aumento da degradação proteolítica de p27. A baixa expressão ou ausência de p27 está associada com maior agressividade do tumor e/ou pior prognóstico. (Tannapfel, 2000). 
Em 2007, Pellegata et al relataram uma família com NEM1 em 3 gerações (HPT, acromegalia e tumor renal) que não apresentava mutação no gene MEN1. Essa família possuía uma mutação germinativa no gene p27(Kip1)/CDKN1B que por ter um fenótipo similar a NEM1 foi denominada NEM1-like (Pellegata, 2006). Logo após, outro estudo confirmou o envolvimento de mutações no gene p27(Kip1)/CDKN1B em casos com NEM1 (Georgitsi, 2007). A partir desses estudos, novas mutações no gene CDKN1B foram identificadas e até o momento foram descritas seis mutações diferentes neste gene (Tabela 3).

Tabela 3: Mutações descritas na literatura no gene $C D K N 1 B$

\begin{tabular}{|c|c|c|c|c|}
\hline p27Kip1 & Descrição da mutação & Fenótipo & Status no tumor & Referência \\
\hline W76X & Proteina truncada & $\begin{array}{l}\text { HPT, acromegalia (tumor hipofisário secretor de GH) - MEN1-lilke } \\
\text { (pai - acromegalia; irmå - angiom yolipoma renal; sobrinho - câncer tessicalar) }\end{array}$ & sem LOH & Pellegata, 2006 \\
\hline K25fs & frameshift - proteina longa & $\begin{array}{l}\text { HPT, tumor hipofisário secretor de ACTH (corticotropinoma) Tumor } \\
\text { carcinóide (neuroendócrino) }\end{array}$ & $\mathrm{LOH}$ & Georgitsi, 2007 \\
\hline ATG-7G $>C$ & Redução da expressão protéica in vitro & HPT, tumor adrenal bilateral não funcionante (2 irmã com mutação) & sem LOH & Agarwal, 2009 \\
\hline P95S & Redução da proteína & HPT (sem dados clínicos da familia) & ND & Agarwal, 2009 \\
\hline Stop $>0$ & Proteína longa - muito instável & HPT (irmã gêmea com HPT e mutação no p27) & ND & Agarwal, 2009 \\
\hline P69L & Proteína instável & $\begin{array}{l}\text { HPT, carcinóide brônquico, carcinoma papilifero de tireóide, } \\
\text { macroadenoma de hipófise e metástase bilateral nos pulmöes }\end{array}$ & ND & Molatore, 2011 \\
\hline
\end{tabular}

O gene p27(Kip1)/CDKN1B codifica uma proteína inibidora de quinase dependente de ciclina (p27), envolvida na regulação do ciclo celular. Está localizado no braço curto do cromossomo 12, região 1, sub-região 3 (12p13), contém 3 éxons. Estudos de animais knock out para esse gene indicaram sua associação com a tumorigênese hipofisária: esses animais desenvolveram hiperplasia/tumor hipofisário aos 3 meses de idade e gigantismo (aumento de diversos órgãos) (Fero, 1996; Kiyokawa, 1996).

Estudos funcionais demonstraram que a proteína MENIN (codificada pelo MEN1) é capaz de controlar a expressão do gene p27(Kip1)/CDKN1B), 
indicando uma via celular comum para tumorigênese da NEM1 em casos com mutação no gene MEN1 e p27Kip1 (Karnik, 2005; Fontaniere, 2006).

Quando, o gene MEN1 não está mutado codifica uma proteína Menin íntegra, que forma um complexo com a metiltrasferase (MLL) e RNA polimerase II (POL II) e regula a transcrição de p27Kip1 através da desmetilação das histonas (Karnik, 2005). Por sua vez, a atividade de p27Kip1 e outras proteínas como a p15, p18 e p21 inibe o complexo Ciclina/CDKs e, assim, impede a fosforilação da proteína retinoblastoma $(\mathrm{Rb})$. O Rb não fosforilado seqüestra o fator de transcrição E2F (responsável pela ativação da passagem da fase G1 para a fase S), controlando assim o ciclo celular (Figura 8).

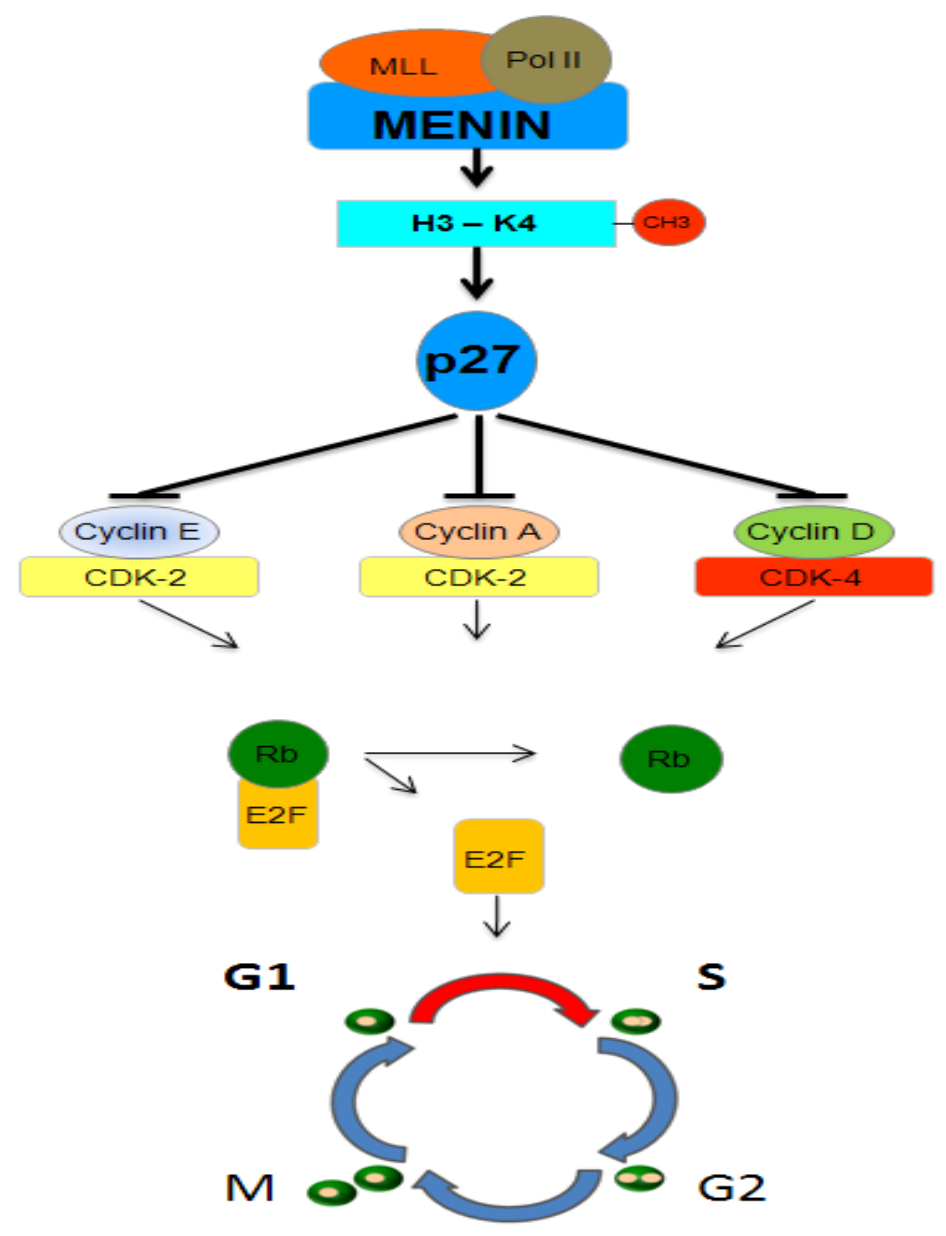

Figura 8: Interação da proteína MENIN com a CDKN1B 
Existem dois polimorfismos encontrados neste gene, que foram utilizados neste estudo, polimorfismo p.V109G é localizado na região codificadora (éxon 1) do gene p27Kip1, mais especificamente em um domínio de ligação de p27 com p38, uma proteína envolvida na degradação de p27 (Tomoda, 1999; Shiraso, 2009). Esta variante polimórfica p.V109G é a mais comum deste gene e foi anteriormente associada a um pior prognóstico, maior risco invasão e progressão tumoral. A outra variante é o c. -79C>T se localiza na região não transcrita do gene p27Kip1 (5" UTR) e foi anteriormente associado a um maior risco de câncer de próstata (Chang BL, 2004) (Figura 9).

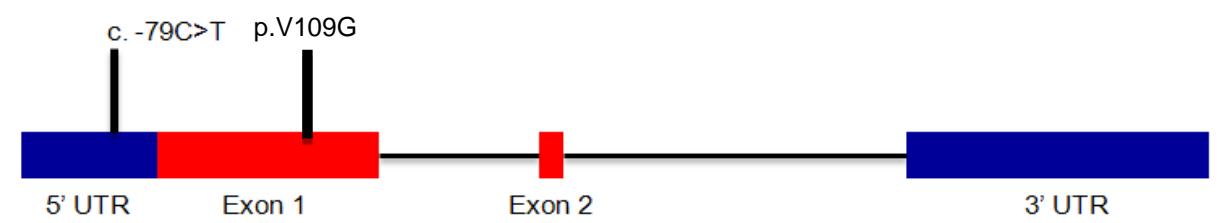

Figura 9: Representação do gene p27Kip1, com a presença dos polimorfismos V109G e C-79C>T

\subsubsection{Gene AIP (XAP2, ARA9)}

Mutações germinativas e inativadoras no gene AIP (aryl hydrocarbon receptor-interacting protein) foram identificadas em aproximadamente $15 \%$ das famílias com tumor hipofisário isolado e em 50\% das famílias com acromegalia isolada (Vierimaa, 2006; Daly, 2007; Toledo, 2007b).

Georgitsi et al também reportaram dois casos clinicamente diagnosticados com NEM1 sem mutação no gene MEN1, mas com mutação germinativa no gene AIP (Georgitsi, 2007). Recentemente, foi identificada em nosso laboratório uma nova mutação germinativa no gene AIP, p.Y268X, que estava presente em amostras de DNA de dois irmãos que desenvolveram acromegalia devido a um adenoma hipofisário secretor de GH (Toledo, 
2007b). Também identificamos um caso com diagnóstico sugestivo de NEM1 atípico (tumor hipofisário e carcinoma adrenocortical) com a mutação germinativa p.R81X no gene AIP (Toledo,2010).

O gene AIP, também chamado XAP2 ou ARA9, codifica uma proteína com o mesmo nome, que a partir de sua interação com o receptor aril hidrocarbono (AHR), está ligada à via de degradação de poluentes (Meyer, 2000). Foi clonado e seqüenciado em 1996, está localizado próximo ao gene MEN1, no braço longo do cromossomo 11, região 1, sub-região 3.3 (11q13.3).

\subsubsection{Genes CDKN2B/P15, CDKN2C/P18 e CDKN1A/P21}

Assim como o gene CDKN1B/p27Kip1, outros genes (CDKN2B, $C D K N 2 C, C D K N 1 A)$ que codificam proteínas inibidoras de quinases dependentes de ciclinas ( $p 15, p 18$ e p21) foram recentemente também estão associados à NEM1. Mutações nesses genes foram identificadas pelo mesmo grupo que clonou o gene MEN1, coordenado pelo dr. Steve Marx (Agarwal, 2009). Através da inibição das quinases dependentes de ciclinas 2, 4 e 6 esses genes possuem papéis importantes no controle do ciclo celular.

A progressão do ciclo celular, da fase $\mathrm{G} 1$ para a fase $S$, ocorre pela ativação do fator de transcrição E2F. A ativação de E2F é regulada por quinases dependentes de ciclina que fosforilam a proteína retinoblastoma $(R b)$, que então libera e ativa E2F. Por sua vez, a atividade das quinases dependentes de ciclina são controladas por p27 e outras proteínas como a p15, p18 e p21 - chamadas de inibidoras de quinases dependentes de ciclina. Portanto, p27, p15, p18 e p21 são proteínas que regulam diretamente o ciclo celular, sendo assim chamadas supressoras de tumor. Mutações inativadoras nos genes que codificam tais proteínas causam superatividade das quinases e descontrole do ciclo celular, levando à tumorigênese (Figura 10). 


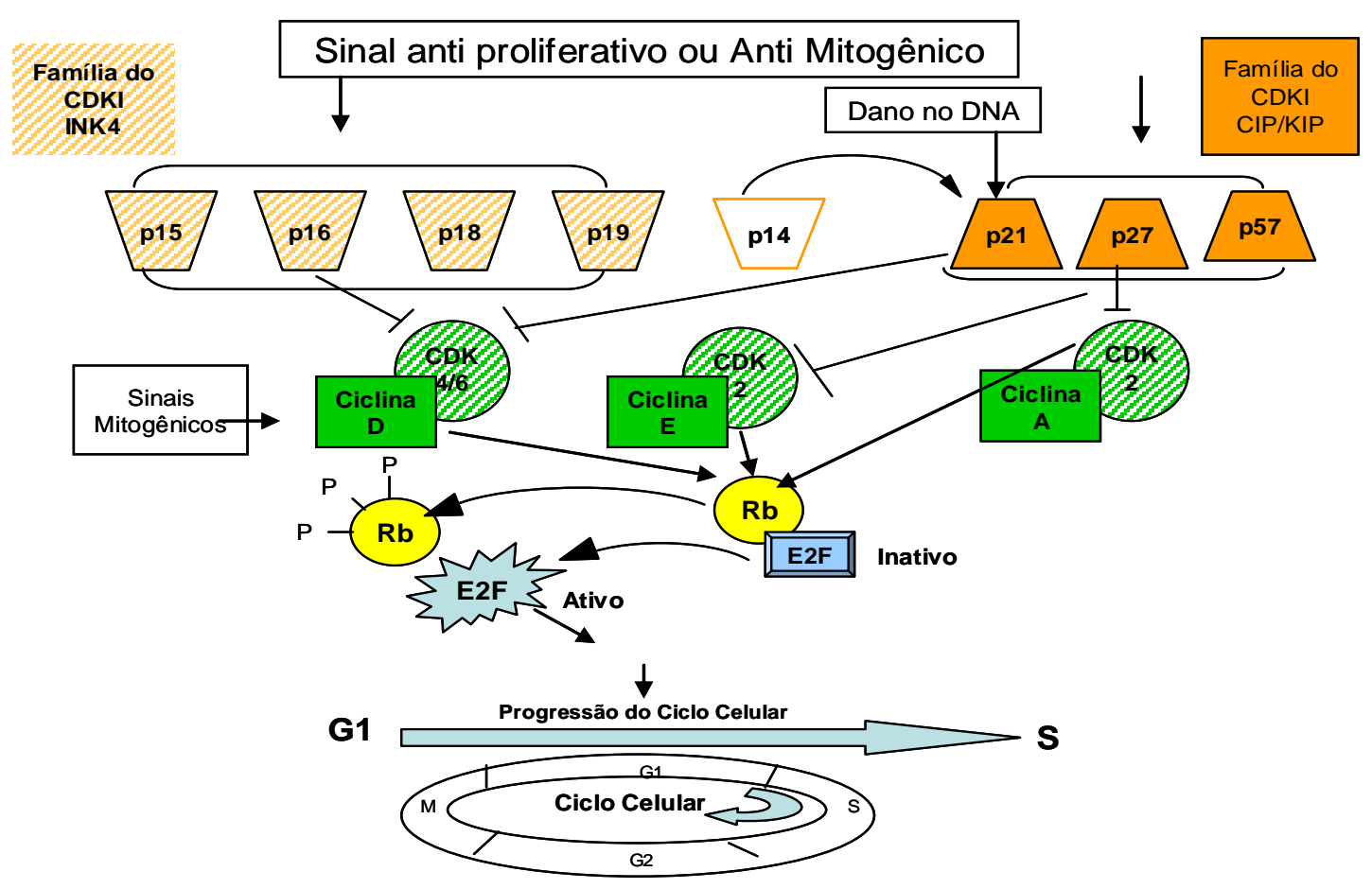

Figura 10: Genes envolvidos na regulação do ciclo celular. (CDKN2B/p15, $\mathrm{CDKN2C} / \mathrm{p} 18, \mathrm{CDKN} 1 \mathrm{~A} / \mathrm{p} 21, \mathrm{CDKN1B} / \mathrm{p} 27)$ recentemente associados à NEM1

\subsection{Metodologia para análise de perda de heterozigose (LOH)}

Existem algumas abordagens para se estudar a perda de heterozigose em tumores, as quais serão discutidas neste estudo.

\subsubsection{Polimorfismos de microssatélites}

A análise de microssatélites é a metodologia mais conhecida e utilizada nestas análises. 
Os marcadores de micro-satélites são um dos marcadores mais polimórficos encontrados no genoma, sendo caracterizados por uma sequência de 1 a 6 nucleotídeos de comprimento, que podem estar repetidas em tandem.

Os marcadores de microssatélites apresentam vantagens, quando comparados com outros tipos de marcadores, pois eles são altamente informativos, o que permite a discriminação entre homozigoto e heterozigoto.

\subsubsection{Análise de perda de heterozigose por análise de mutação}

Uma outra metodologia que vem sido muito bem aceita e sendo publicadas em revistas de importante impacto, como um recente estudo publicado na Science (Verimma 2006) é por análise de mutação .

Esta é uma metodologia realizada através de sequenciamento gênico, onde já é conhecida a mutação germinativa do paciente, como nos casos com NEM1, nos quais todas as mutações são encontradas em heterozigose. A análise de LOH é feita no ponto especifico da mutação.

A figura 11 abaixo representa esta análise. Na coluna da esquerda representa análise do sangue do paciente onde a seta indica a presença de dois alelos. Na coluna da direita, representa análise de LOH de tumores na qual a seta indica a presença de apenas um alelo, ou seja, LOH no tecido estudado. 


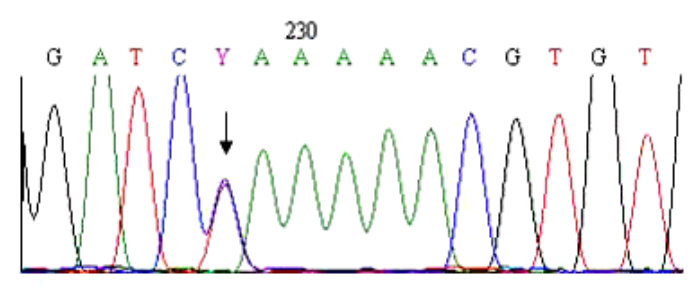

A A6-normal

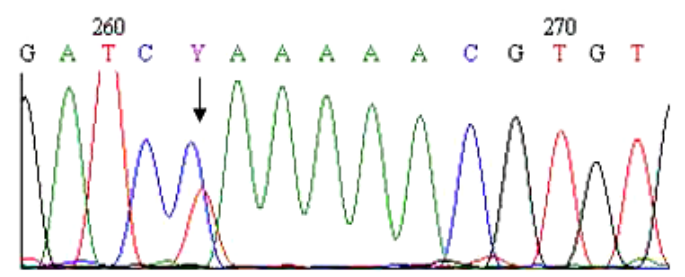

B A.13 - normal
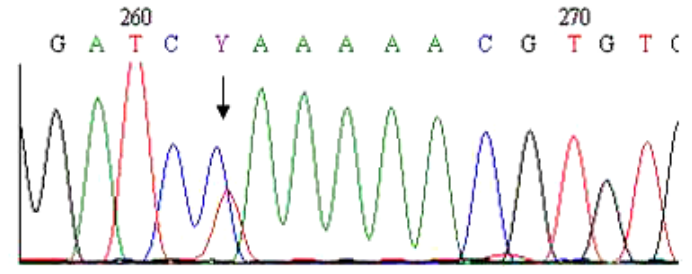

C A20 - normal

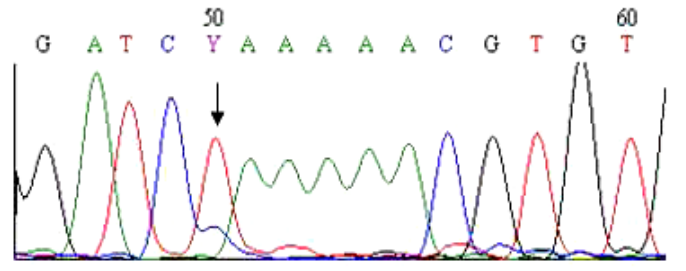

A6 - tumor with $\mathrm{LOH}$

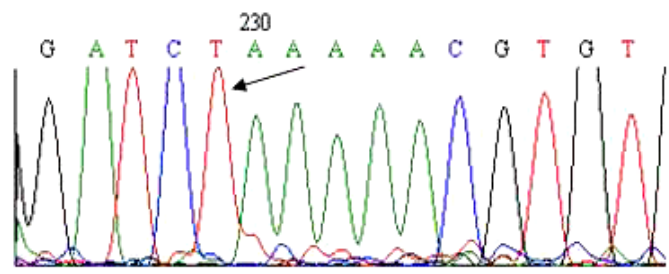

A13 - tumor with $\mathrm{LOH}$

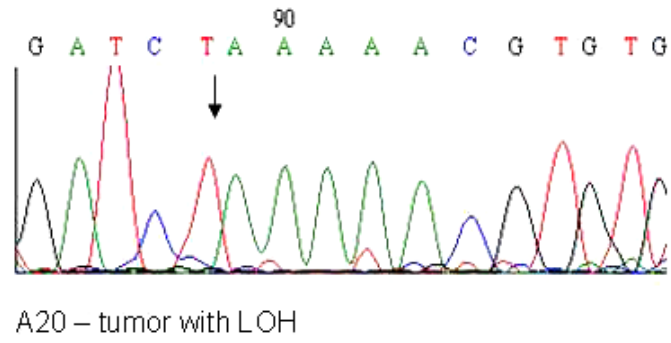

Figura 11: Análise de LOH por seqüenciamento gênico, análise em pontos específicos, na qual a mutação já é conhecida 
2 OBJETIVOS 
Pesquisar eventos moleculares somáticos (mutação, perdas cromossômicas) dos genes MEN1, p27Kip1/CDKN1B e AIP, em tecidos tumorais de pacientes com mutação germinativa e verificar, assim, seu envolvimento no processo multistep da tumorigênese dessa síndrome. 
3 PACIENTES 
Amostras de DNA de leucócitos e tumores de trinta e oito pacientes do HC-FMUSP com NEM1, previamente diagnosticados clínica e geneticamente com NEM1 por nosso grupo (Toledo, 2007; Lourenço DM, 2006) foram incluídos nesse estudo. Ao total, DNAs de 145 tecidos tumorais foram extraídos, sendo: 60 hiperplasias/tumores da paratireóide, 15 carcinoides, 22 tumores entero-pancreáticos, 5 tumores de duodeno, 3 tumores adreno-corticais, 1 tumor hipofisário e 22 tumores de pele. 
4 MÉTODOS 
Os experimentos envolvidos nesse projeto foram realizados no LIM25, Unidade de Endocrinologia Genética, Endocrinologia, HC-FMUSP, e todos os pacientes assinaram termo de consentimento livre e esclarecido aprovado pela Cappesq. O presente projeto foi também aprovado por este Comitê de Ética.

\subsection{Extração de DNA}

As amostras de DNA de tecidos neoplásicos foi realizada, através de duas metodologias diferentes, extração de DNA de tumores coletados durante o procedimento cirúrgico, e tumores vindos da seção de Patologia cirúrgicas do HC-FMUSP em blocos de parafina. O DNA dos tumores emblocados foi extraído com pré-incubação com Xilol e posterior uso de Kit, enquanto o DNA dos tumores congelados foram extraídos por kit ou Fenol e Clorofórmio, de acordo com o protocolo sugerido pelo fabricante (Sigma e Gerba).

Para padronização do método, foram utilizados tecidos com lesões no pulmão, pâncreas, barriga, nariz, lábio, paratireóides (direita e esquerda), lesões de tórax e tronco. 


\subsection{Eletroforese em gel de agarose}

A integridade das moléculas de DNA foi avaliada por meio de eletroforese em gel de agarose 1\%. Depois da quantificação, foi realizada a diluição das amostras para que a concentração final de DNA destas amostras ficasse em torno de $100 \mathrm{ng} / \mu \mathrm{l}$.

\subsection{Amplificação gênica}

As reações de PCRs (Polymerase Chain Reaction) realizadas para análise de perda de heterozigose e mutação somática do gene p27(Kip1)/CDKN1B amplificaram toda a região codificadora do gene p27(Kip1)/CDKN1B (2 éxons), assim como as fronteiras éxons/íntrons.

A reação de PCR foi otimizada sob as seguintes condições: Buffer $1 \mathrm{X}$ (200 mmol Tris-Hcl com pH 8.4 e $500 \mathrm{mmol} / / \mathrm{de} \mathrm{Kcl}$ ) e MgCl2 $2 \mathrm{mM} ; 0,2 \mathrm{mM}$ de dNTP (Mix dNTP"s 25 mM) (Kit Invitrogen, Brasil); 200 ng de DNA genômico, 0,2 $\mu \mathrm{M}$ de cada um dos oligonucleotídeos iniciadores (senso ou reverso) e $1 \mathrm{U}$ de Taq DNA polimerase.

Um único programa de 30 ciclos foi padronizado para todas PCRs nas seguintes condições: Buffer 1X (200 mmol Tris-HCL com pH 8.4 e 500 $\mathrm{mmol} / \mathrm{l} \mathrm{de} \mathrm{Kcl}$ ) e $\mathrm{Mgcl}_{2} 2 \mathrm{Mm} ; 0,2 \mathrm{Mm}$ DE Dntp (Mix dNTP's $25 \mathrm{mM}$ ) Kit Invitrogen, Brasil); 200ng de DNA (tecido tumoral), e 0,2 $\mu \mathrm{M}$ de cada um dos oligonucleotídeos iniciadores (senso ou reverso) e $1 U$ de Taq DNA polimerase. 


\subsection{Purificação dos produtos de PCRs}

Os produtos de PCRs foram primeiramente purificados com uso de enzima ExoSAP-IT (USB Cooperation), para cada $5 \mu \mathrm{l}$ do produto de PCR foram adicionados $2 \mu \mathrm{l}$ de ExoSAP-IT e digerido por $1 \mathrm{~h} 37^{\circ} \mathrm{C}$, seguido por $15 \mathrm{~min}$ por $80^{\circ} \mathrm{C}$.

\subsection{Reação de sequenciamento}

O kit Big dye é constituído de nucleotídeos (dATP, dGTP, dCTP, dTTP), buffer, cloreto de magnésio, Ampli Taq DNA polimerase FS e os dideoxinucleotídeos (ddATP, ddGTP, ddCTP, ddTTP) ligados à moléculas fluorescentes de alta sensibilidade denominadas dicloro-rodaminas. As dicloro-rodaminas dicloro R6G, dicloro ROX, dicloro R110 e dicloro TAMRA são ligadas respectivamente às ddATP, ddCTP, ddGTP e ddTTP. As diclororodaminas são moléculas aceptoras de fluorescência e são ligadas por sua vez a moléculas doadoras de fluorescência, a 6-carboxi-fluoresceína (6 FAM).

As reações de seqüenciamento foram realizadas para um volume final de $10 \mu \mathrm{l}$ contendo: $1 \mu \mathrm{L}$ de Big dye, $2 \mu \mathrm{L}$ de tampão $5 \mathrm{X}, 1 \mu \mathrm{L}$ do oligonucleotídeo senso ou reverso ( $5 \mathrm{pmol} / \mu \mathrm{L}), 4-6$ ul do produto de PCR purificado completando-se o volume final para $10 \mu \mathrm{L}$ com água Milliq.

O programa de PCR utilizado para o seqüenciamento foi o seguinte:

$1^{a}$ fase - temperatura de denaturação: $94^{\circ}$ C 3 min.;

$2^{a}$ fase - temperatura de denaturação: $94^{\circ}$ C 30 seg.;

$3^{\mathrm{a}}$ fase - temperatura de anelamento: $50^{\circ} \mathrm{C} 4 \mathrm{~min}$.;

$4{ }^{\mathrm{a}}$ fase - 29 ciclos repetitivos, partindo da $2^{\mathrm{a}}$ até a $3^{\mathrm{a}}$ fase 


\subsection{Reação de precipitação}

A- Para cada amostra contendo $10 \mu$ de reação de sequenciamento foram

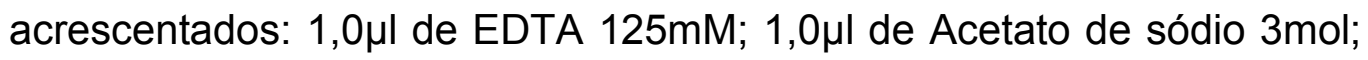
$25 \mu$ l Etanol absoluto;

B- A solução foi homogeneizada, submetida a um "spin" e deixada à temperatura ambiente por 15 min. protegida da luz;

C- Encaminhadas novamente à centrifugação à $2000 \mathrm{~g}$ por $45 \mathrm{~min}$. a $4^{\circ} \mathrm{C}$, seguido de remoção de todo o sobrenadante;

D- Foram adicionados $35 \mu$ l; seguido de $15 \mathrm{~min}$. de centrifugação $1650 \mathrm{~g}$ a $4^{\circ} \mathrm{C}$;

E- Ao final da centrifugação, foi removido todo o sobrenadante;

F- As amostras foram secas em banho seco.

\subsection{Seqüenciamento}

Para o seqüenciamento, utilizamos o seqüenciador $\mathrm{ABI}-3130 \mathrm{XL}$ (Applied Biosystems, Foster City, CAL, USA), com 16 capilares. .

\subsection{Análise do seqüenciamento}

As análises dos eletroferogramas foram realizadas através de softwares de edição de seqüências (mutation surveyor), por dois pesquisadores. 


\subsection{Estudo de perda de heterozigose (LOH) do locus do gene MEN1}

Para o estudo de eventual perda de heterozigose nos tecidos tumorais de pacientes com NEM1 foram utilizados duas técnicas: análise de regiões polimórficas nos genes candidatos e analise de marcadores de microssatélite que flanqueiam as regiões cromossômicas dos genes candidatos (Tabelas 4 e 5).

Resultados evidenciando uma perda somática de sinal $\geq 50 \%$ foram considerados compatíveis com LOH do locus 11q13. Resultados evidenciando uma perda somática de sinal $<50 \%$ serão interpretados como manutenção de heterozigose $(\mathrm{MOH})$.

Tabela 4: Lista dos primers utilizados para a análise dos marcadores de microssatélites localizados na região 11q13/MEN1

\begin{tabular}{lll}
\hline Primer & Seqüência $\left(\mathbf{5}^{\prime} \rightarrow \mathbf{3}^{\prime}\right)$ & Localização \\
\hline PYGM-F & CTAGCAGAGTCCACCTACTG & $11 \mathrm{q} 13$ \\
PYGM-R & CTAGCAGAGTCCACCTACTG & $11 \mathrm{q} 13$ \\
\hline
\end{tabular}


Tabela 5: Lista dos oligonucleotídeos utilizados para estudo genético do MEN1

\begin{tabular}{|c|c|c|c|}
\hline Exon & oligonucleotídeos - PCR (5' - 3') & $\begin{array}{l}\text { Produto } \\
\text { (pb) }\end{array}$ & $\begin{array}{l}\text { Oligonucleotídeos - } \\
\text { seqüenciamento }\end{array}$ \\
\hline $2 \mathrm{~F}$ & GGAACCTTAGCGGACCCTGGGAG & & \\
\hline $2 \mathrm{R}$ & GGTGAGCTCGGGAACGTTGGTAG & 287 & GGTGAGCTCGGGAACGTTGGTAG \\
\hline $2 \mathrm{~F}$ & ATCGACGACGTGGTGCGCCTGTTTG & 625 & GGCTGTCAACCGCGTCAT \\
\hline $2 \mathrm{R}$ & GAGGTGAGGTTGATGATTTGGAG & & CGAACCTCACAAGGCTTACAGTTC \\
\hline $2 \mathrm{AF}$ & TGGAGCATTTTCTGGCTGTC & 294 & TGGAGCATTTTCTGGCTGTC \\
\hline $3-4 F$ & AGTGTGGCCCATCACTACCT & 677 & TGGGTGGCTTGGGCTACTACAG \\
\hline $3-4 R$ & GGTCCCACAGCAAGTCAAGTCTGG & & GGGCCATCATGAGACATAATG \\
\hline $5-6 \mathrm{~F}$ & CCTGTTCCGTGGCTCATAACTCTC & & ATAATTCAGGCTGCCACC \\
\hline $5-6 R$ & СССTGCCTCAGCCACTGTTA & 305 & GGAAGTGGCCAGGCTGCG \\
\hline $7 \mathrm{~F}$ & CCTCAGCCAGCAGTCCTGTAGA & & \\
\hline $7 \mathrm{R}$ & GGACGAGGGTGGTTGGAAACTG & 403 & GGCTGCCTCCCTGAGGAT \\
\hline $8 \mathrm{~F}$ & AACCACCATCATCCAGCAGTGG & & \\
\hline $8 \mathrm{R}$ & ССАТСССТААТСССGTACATGC & 457 & TGGTGAGACCCCTTCAGACCCTAC \\
\hline $9-10 \mathrm{~F}$ & CTGCTAAGGGGTGAGTAAGAGAC & 1000 & GTCTGACAAGCCCGTGGCTGCTG \\
\hline $9-10 R$ & GGTTTGATACAGACTGTACTCGG & & AGCCACTGGCCGGCAACC \\
\hline
\end{tabular}

$\mathrm{pb}=$ nucleotídeos

\subsection{Análise de mutação somática e de LOH do gene CDKN1B em tumores de pacientes com NEM1}

Para a análise de possíveis mutações somáticas no gene p27Kip1/CDKN1B, foram desenhados primers para amplificação de suas regiões codificadoras. $A$ análise de $\mathrm{LOH}$ foi realizada através de polimorfismos descritos anteriormente na literatura (Tabela 6). 
Tabela 6: Lista dos primers utilizados para a análise localizados no gene p27Kip1/CDKN1

\begin{tabular}{ccc}
\hline Primer & Seqüência (5"--> 3") & Produto (pb) \\
\hline $\mathbf{1 A F}$ & GTCGGGGTCTGTGTCTTTTG & 297 \\
$\mathbf{1 A R}$ & CCATGTCTCTGCAGTGCTTC & \\
\hline $\mathbf{1 B F}$ & TGTCTAACGGGAGCCCTAGC & 249 \\
$\mathbf{1 B R}$ & AGTAGAACTCGGGCAAGCTG & 299 \\
\hline $\mathbf{1 C F}$ & AGTTAACCCGGGACTTGGAG & \\
$\mathbf{1 C R}$ & GTCCGACGGATCAGTCTTTG & 312 \\
\hline $\mathbf{1 D F}$ & AGGAGAGCCAGGATGTCAGC & 294 \\
$\mathbf{1 D R}$ & GCCAGGTAGCACTGAACACC & \\
\hline $\mathbf{2 F}$ & CTGACTATGGGGCCAACTTC & \\
\hline
\end{tabular}

\subsection{Análise de mutação somática e de LOH do gene AIP em tumores de pacientes com NEM1.}

Para o estudo de eventual perda de heterozigose nos tecidos tumorais de pacientes com NEM1 foram utilizados dois marcadores de microssatélite que flanqueiam a região cromossômica 11q13, (na qual o gene MEN1 está localizado), D11S1258 e D11S2072. Ao primer senso dos marcadores D11S1258 e D11S2072 foi incorporada fluorescência HEX (azul) (Tabela 7).

Os produtos de PCR utilizando amostras de sangue periférico e de tecido tumoral foram analisados em seqüenciador automático, genotipados e comparados.

A segunda técnica utilizada foi através de análise de mutação, por seqüenciamento gênico através de polimorfismos já descritos na literatura (Tabela 8). 
Tabela 7: Lista dos primers utilizados para a análise dos marcadores de microssatélites localizados na região 11q13/AIP

\begin{tabular}{llc}
\hline Primer & Seqüência $\left(\mathbf{5}^{\prime} \rightarrow \mathbf{3}^{\prime}\right)$ & Localização \\
\hline D11S1258-F & AGTACAGAAACTCAACTCCAAGAGA & $11 q 13.3$ \\
D11S1258-R & GTGGACTGTGATGTAGGTTATGGCTGAGAG & $11 q 13.3$ \\
D11S2072-F & ATGGCTTCTGTTAAAAAAATAAAG & $11 q 13.3$ \\
D11S2072-R & TCTCAGTGTTACATTATAAGTGA & $11 q 13.3$ \\
\hline
\end{tabular}

Tabela 8: Lista do primer utilizado para a análise localizados no gene AIP

\begin{tabular}{lll}
\hline Primer & Seqüência $\left(\mathbf{5}^{\prime} \rightarrow \mathbf{3}^{\prime}\right)$ & Produto \\
\hline $4 / 5 \mathrm{~F}$ & ATGTGGGTCAGGTCTGCTG & 587 \\
$4 / 5 \mathrm{R}$ & AAAGGCTAGGTCTTGACCCC & 587 \\
\hline
\end{tabular}


5 RESULTADOS 
Ao total, cento e quarenta e cinco amostras de tecidos neoplásicos coletados durante cirurgias de pacientes com NEM1 que leram e assinaram o Termo de Consentimento Esclarecido do estudo, aprovado pela Cappesq foram incluídos no estudo e foram analisados pro técnica de análise de mutação.

Como apresentado na tabela 12, foram estudadas amostras de DNA de 15 tumores NEM1-relacionados por marcadores de microssatélites, de 12 pacientes com NEM1. Os tumores estudados foram: adenomas de paratireóides, tumores entero-pancreáticos (insulinomas, gastrinomas), tumores de pele (angiofibroma, carcinoma epidermóide bem diferenciado invasivo) e neoplasia adrenal (hiperplasia).

\subsection{Análise somática do gene MEN1 em tumores de pacientes com NEM1 por seqüenciamento gênico}

De um total de 145 amostras de tecido de pacientes com NEM1, 116 foram informativas quanto ao status somático do gene MEN1. Setenta e seis tumores apresentaram evidências de perda somática do alelo normal do gene MEN1 e foram classificadas como amostras com LOH. Ao total, $\mathrm{LOH}$ foi caracterizadas em 41 neoplasias provenientes das paratireóides (hiperplasia/adenoma), 11 tumores pancreáticos, 12 carcinóides, 4 lesões dérmicas e 7 tecidos que solicitamos revisão do anátomo-patológico (Tabela 9).

Resultados compatíveis com manutenção de heterozigose foram observados em 40 amostras de neoplasias NEM1, incluindo tumores adrenocorticais, amostra proveniente de duodeno e paratireóides. 
Tabela 9: Análise do status somático do gene MEN1

\begin{tabular}{|c|c|c|c|c|}
\hline \multirow[b]{2}{*}{ Pacientes } & \multirow[b]{2}{*}{ Tumores } & \multirow[b]{2}{*}{ Tumor } & \multicolumn{2}{|c|}{ Status MEN1 } \\
\hline & & & Germinativo & Somático \\
\hline \multirow{4}{*}{ Individuo 1} & 1 & $\begin{array}{l}\text { hiperplasia } \\
\text { Paratireóide }\end{array}$ & Mutado & $\mathrm{LOH}$ \\
\hline & 2 & $\begin{array}{l}\text { hiperplasia } \\
\text { Paratireóide }\end{array}$ & Mutado & $\mathrm{LOH}$ \\
\hline & 3 & $\begin{array}{l}\text { hiperplasia } \\
\text { Paratireóide }\end{array}$ & Mutado & $\mathrm{LOH}$ \\
\hline & 138 & Lesão sem identificação & Mutado & $\mathrm{MOH}$ \\
\hline \multirow{4}{*}{ Individuo 2} & 149 & $\begin{array}{l}\text { HIPERPLASIA NODULAR E } \\
\text { DIFUSA DE CÉLULAS } \\
\text { PRINCIPAIS E OXIFÍLICAS }\end{array}$ & Mutado & $\mathrm{LOH}$ \\
\hline & & Paratireóide & & \\
\hline & 5 & $\begin{array}{c}\text { colagenoma } \\
\text { Lesão de Tronco }\end{array}$ & Mutado & $\mathrm{LOH}$ \\
\hline & 169 & $\begin{array}{l}\text { angiofibroma } \\
\text { Lesão nariz }\end{array}$ & Mutado & $\mathrm{MOH}$ \\
\hline \multirow{2}{*}{ Individuo 3} & 7 & $\begin{array}{l}\text { HIPERPLASIA DE CÉLULAS } \\
\text { PRINCIPAIS }\end{array}$ & Mutado & $\mathrm{MOH}$ \\
\hline & 8 & $\begin{array}{c}\text { HIPERPLASIA DE CÉLULAS } \\
\text { PRINCIPAIS }\end{array}$ & Mutado & $\mathrm{MOH}$ \\
\hline \multirow{3}{*}{ Individuo 4} & 11 & $\begin{array}{c}\text { colagenoma } \\
\text { Lesão de Tronco }\end{array}$ & Mutado & $\mathrm{LOH}$ \\
\hline & 13 & $\begin{array}{c}\text { colagenoma } \\
\text { Lesão de Tronco }\end{array}$ & Mutado & $\mathrm{LOH}$ \\
\hline & 15 & $\begin{array}{c}\text { colagenoma } \\
\text { Lesão de Tronco }\end{array}$ & Mutado & $\mathrm{LOH}$ \\
\hline \multirow{6}{*}{ Individuo 5} & 16 & Paratireóide & Mutado & $\mathrm{LOH}$ \\
\hline & 17 & Paratireóide & Mutado & $\mathrm{LOH}$ \\
\hline & 18 & Paratireóide & Mutado & $\mathrm{LOH}$ \\
\hline & 19 & Paratireóide & Mutado & $\mathrm{LOH}$ \\
\hline & 20 & Paratireóide & Mutado & $\mathrm{LOH}$ \\
\hline & 21 & Paratireóide & Mutado & $\mathrm{LOH}$ \\
\hline
\end{tabular}

Continua... 
Continuação Tabela 9

\begin{tabular}{|c|c|c|c|c|}
\hline \multirow[b]{2}{*}{ Pacientes } & \multirow[b]{2}{*}{ Tumores } & \multirow[b]{2}{*}{ Tumor } & \multicolumn{2}{|c|}{ Status MEN1 } \\
\hline & & & Germinativo & Somático \\
\hline \multirow{10}{*}{ Individuo 6} & 22 & $\begin{array}{l}\text { hiperplasia } \\
\text { Paratireóide }\end{array}$ & Mutado & $\mathrm{MOH}$ \\
\hline & 23 & $\begin{array}{l}\text { hiperplasia } \\
\text { Paratireóide }\end{array}$ & Mutado & $\mathrm{MOH}$ \\
\hline & 24 & $\begin{array}{l}\text { hiperplasia } \\
\text { Paratireóide }\end{array}$ & Mutado & $\mathrm{LOH}$ \\
\hline & 26 & $\begin{array}{l}\text { hiperplasia } \\
\text { Paratireóide }\end{array}$ & Mutado & $\mathrm{LOH}$ \\
\hline & 27 & $\begin{array}{l}\text { hiperplasia } \\
\text { Paratireóide }\end{array}$ & Mutado & $\mathrm{MOH}$ \\
\hline & 28 & $\begin{array}{l}\text { hiperplasia } \\
\text { Paratireóide }\end{array}$ & Mutado & $\mathrm{LOH}$ \\
\hline & 30 & $\begin{array}{l}\text { hiperplasia } \\
\text { Paratireóide }\end{array}$ & Mutado & $\mathrm{LOH}$ \\
\hline & 31 & Paratireóide & Mutado & $\mathrm{MOH}$ \\
\hline & 33 & $\begin{array}{l}\text { hiperplasia } \\
\text { Paratireóide }\end{array}$ & Mutado & $\mathrm{LOH}$ \\
\hline & 34 & $\begin{array}{l}\text { hiperplasia } \\
\text { Paratireóide }\end{array}$ & Mutado & $\mathrm{LOH}$ \\
\hline \multirow[t]{10}{*}{ Individuo 7} & 44 & Gastrinoma & Mutado & $\mathrm{MOH}$ \\
\hline & 49 & $\begin{array}{l}\text { TNE pancreático não funcionante } \\
\qquad \mathrm{KI} 67>2 \%\end{array}$ & Mutado & $\mathrm{LOH}$ \\
\hline & 51 & $\begin{array}{l}\text { TNE pancreático não funcionante } \\
\text { KI } 67>2 \%\end{array}$ & Mutado & $\mathrm{LOH}$ \\
\hline & 52 & $\begin{array}{l}\text { TNE pancreático não funcionante } \\
\qquad \mathrm{KI} 67>2 \%\end{array}$ & Mutado & $\mathrm{LOH}$ \\
\hline & 132 & Hiperplasia & Mutado & $\mathrm{LOH}$ \\
\hline & 47 & $\begin{array}{l}\text { TNE pancreático não funcionante } \\
\qquad \mathrm{KI} 67>2 \%\end{array}$ & Mutado & $\mathrm{NI}$ \\
\hline & 48 & $\begin{array}{l}\text { TNE pancreático não funcionante } \\
\text { KI } 67>2 \%\end{array}$ & Mutado & $\mathrm{NI}$ \\
\hline & 50 & $\begin{array}{l}\text { TNE pancreático não funcionante } \\
\text { KI } 67>2 \%\end{array}$ & Mutado & $\mathrm{NI}$ \\
\hline & 117 & Hiperplasia & Mutado & $\mathrm{NI}$ \\
\hline & 49 & $\begin{array}{l}\text { TNE pancreático não funcionante } \\
\qquad K 167>2 \%\end{array}$ & Mutado & $\mathrm{LOH}$ \\
\hline
\end{tabular}


Continuação Tabela 9

\begin{tabular}{|c|c|c|c|c|}
\hline \multirow[b]{2}{*}{ Pacientes } & \multirow[b]{2}{*}{ Tumores } & \multirow[b]{2}{*}{ Tumor } & \multicolumn{2}{|c|}{ Status MEN1 } \\
\hline & & & Germinativo & Somático \\
\hline \multirow{2}{*}{ Individuo 8} & 58 & Paratireóide & Mutado & $\mathrm{LOH}$ \\
\hline & 59 & Paratireóide & Mutado & $\mathrm{LOH}$ \\
\hline \multirow{3}{*}{ Individuo 9} & 61 & $\begin{array}{c}\text { colagenoma } \\
\text { Lesão Barriga }\end{array}$ & Mutado & $\mathrm{MOH}$ \\
\hline & 62 & $\begin{array}{c}\text { colagenoma } \\
\text { Lesão Barriga }\end{array}$ & Mutado & $\mathrm{MOH}$ \\
\hline & 63 & $\begin{array}{l}\text { tNE pancreático não funcionante } \\
\text { ou insulinoma, sem metástase local } \\
\text { Pâncreas }\end{array}$ & Mutado & $\mathrm{MOH}$ \\
\hline \multirow[t]{9}{*}{ Individuo 10} & 70 & $\begin{array}{c}\text { hiperplasia } \\
\text { Paratireóide }\end{array}$ & Mutado & $\mathrm{LOH}$ \\
\hline & 71 & $\begin{array}{l}\text { hiperplasia } \\
\text { Paratireóide }\end{array}$ & Mutado & $\mathrm{LOH}$ \\
\hline & 91 & $\begin{array}{c}\text { hiperplasia } \\
\text { adrenal }\end{array}$ & Mutado & $\mathrm{MOH}$ \\
\hline & 92 & $\begin{array}{c}\text { Carcinóide brônquico com } \\
\text { metástase }\end{array}$ & Mutado & $\mathrm{MOH}$ \\
\hline & 94 & $\begin{array}{c}\text { hiperplasia } \\
\text { Paratireóide }\end{array}$ & Mutado & $\mathrm{MOH}$ \\
\hline & 95 & $\begin{array}{c}\text { hiperplasia } \\
\text { Paratireóide }\end{array}$ & Mutado & $\mathrm{LOH}$ \\
\hline & 96 & $\begin{array}{l}\text { Carcinóide brônquico com } \\
\text { metástase }\end{array}$ & Mutado & $\mathrm{LOH}$ \\
\hline & 97 & $\begin{array}{c}\text { Carcinóide brônquico com } \\
\text { metástase }\end{array}$ & Mutado & $\mathrm{LOH}$ \\
\hline & 98 & $\begin{array}{c}\text { Carcinóide brônquico com } \\
\text { metástase }\end{array}$ & Mutado & $\mathrm{LOH}$ \\
\hline \multirow[t]{8}{*}{ Individuo 11} & 99 & $\begin{array}{l}\text { Carcinóide brônquico com } \\
\text { metástase }\end{array}$ & Mutado & $\mathrm{LOH}$ \\
\hline & 100 & $\begin{array}{c}\text { Carcinóide brônquico com } \\
\text { metástase }\end{array}$ & Mutado & $\mathrm{LOH}$ \\
\hline & 102 & $\begin{array}{c}\text { Carcinóide brônquico com } \\
\text { metástase }\end{array}$ & Mutado & $\mathrm{LOH}$ \\
\hline & 103 & $\begin{array}{c}\text { Carcinóide brônquico com } \\
\text { metástase }\end{array}$ & Mutado & $\mathrm{LOH}$ \\
\hline & 104 & $\begin{array}{c}\text { Carcinóide brônquico com } \\
\text { metástase }\end{array}$ & Mutado & $\mathrm{LOH}$ \\
\hline & 105 & $\begin{array}{c}\text { Carcinóide brônquico com } \\
\text { metástase }\end{array}$ & Mutado & $\mathrm{LOH}$ \\
\hline & 106 & $\begin{array}{c}\text { hiperplasia } \\
\text { adrenal } \\
\end{array}$ & Mutado & $\mathrm{MOH}$ \\
\hline & 107 & $\begin{array}{l}\text { hiperplasia } \\
\text { adrenal }\end{array}$ & Mutado & $\mathrm{MOH}$ \\
\hline
\end{tabular}


Continuação Tabela 9

\begin{tabular}{|c|c|c|c|c|}
\hline \multirow[b]{2}{*}{ Pacientes } & \multirow[b]{2}{*}{ Tumores } & \multirow[b]{2}{*}{ Tumor } & \multicolumn{2}{|c|}{ Status MEN1 } \\
\hline & & & Germinativo & Somático \\
\hline \multirow{2}{*}{ Individuo 12} & 153 & Hiperplasia de paratireóide & Mutado & $\mathrm{LOH}$ \\
\hline & 154 & Hiperplasia de paratireóide & Mutado & $\mathrm{LOH}$ \\
\hline \multirow{3}{*}{ Individuo $13^{-}$} & 206 & $\begin{array}{l}\text { TNE pancreático não funcionante; } \\
\text { sem metástase; KI67 1\% }\end{array}$ & Mutado & $\mathrm{LOH}$ \\
\hline & 204 & Pâncreas & Mutado & $\mathrm{LOH}$ \\
\hline & 189 & $\begin{array}{l}\text { HIPERPLASIA NODULAR E } \\
\text { DIFUSA DE CÉLULAS } \\
\text { PRINCIPAIS E OXIFÍLICAS SEM } \\
\text { ATIPIAS EM PARATIREOIDE }\end{array}$ & Mutado & $\mathrm{LOH}$ \\
\hline Individuo 14 & 194 & $\begin{array}{l}\text { HIPERPLASIA DE CÉLULAS } \\
\text { PRINCIPAIS E OXÍNTICAS }\end{array}$ & Mutado & $\mathrm{LOH}$ \\
\hline \multirow{2}{*}{ Individuo 15} & 176 & $\begin{array}{l}\text { TNE pancreático não funcionante } \\
\text { (metástases) }\end{array}$ & Mutado & $\mathrm{MOH}$ \\
\hline & 188 & $\begin{array}{l}\text { TNE pancreático não funcionante } \\
\text { (metástases) }\end{array}$ & Mutado & $\mathrm{MOH} / \mathrm{LOH}$ \\
\hline \multirow{7}{*}{ Individuo 16} & 177 & $\begin{array}{l}\text { Gastrinoma } \\
\text { (duodeno) }\end{array}$ & Mutado & $\mathrm{MOH}$ \\
\hline & 178 & $\begin{array}{c}\text { CARCINOMA } \\
\text { NEUROENDÓCRINO BEM } \\
\text { DIFERENCIADO METASTÁTICO } \\
\text { KI67 POSITIVO (BAIXO ÍNDICE } \\
<2 \% \text { - }\end{array}$ & Mutado & $\mathrm{MOH}$ \\
\hline & 181 & $\begin{array}{l}\text { Gastrinoma } \\
\text { (duodeno) }\end{array}$ & Mutado & $\mathrm{MOH}$ \\
\hline & 184 & $\begin{array}{c}\text { CARCINOMA } \\
\text { NEUROENDÓCRINO BEM } \\
\text { DIFERENCIADO METASTÁTICO } \\
\text { KI67 POSITIVO (BAIXO ÍNDICE } \\
<2 \% \text { ) - (pâncreas) }\end{array}$ & Mutado & $\mathrm{LOH}$ \\
\hline & 185 & $\begin{array}{c}\text { CARCINOMA } \\
\text { NEUROENDÓCRINO BEM } \\
\text { DIFERENCIADO METASTÁTICO } \\
\text { KI67 POSITIVO (BAIXO ÍNDICE } \\
<2 \% \text { ) - (pâncreas) }\end{array}$ & Mutado & $\mathrm{LOH}$ \\
\hline & 174 & $\begin{array}{c}\text { CARCINOMA } \\
\text { NEUROENDÓCRINO BEM } \\
\text { DIFERENCIADO METASTÁTICO } \\
\text { KI67 POSITIVO (BAIXO ÍNDICE } \\
<2 \% \text { ) - (pâncreas) }\end{array}$ & Mutado & $\mathrm{LOH}$ \\
\hline & 180 & $\begin{array}{c}\text { CARCINOMA } \\
\text { NEUROENDÓCRINO BEM } \\
\text { DIFERENCIADO METASTÁTICO } \\
\text { KI67 POSITIVO (BAIXO ÍNDICE } \\
<2 \% \text { - (pâncreas) }\end{array}$ & Mutado & $\mathrm{LOH}$ \\
\hline
\end{tabular}


Continuação Tabela 9

\begin{tabular}{|c|c|c|c|c|}
\hline \multirow[b]{2}{*}{ Pacientes } & \multirow[b]{2}{*}{ Tumores } & \multirow[b]{2}{*}{ Tumor } & \multicolumn{2}{|c|}{ Status MEN1 } \\
\hline & & & Germinativo & Somático \\
\hline \multirow{3}{*}{$\begin{array}{l}\text { Continuação } \\
\text { Individuo } 16\end{array}$} & 175 & $\begin{array}{c}\text { Gastrinoma } \\
\text { (duodeno) }\end{array}$ & Mutado & $\mathrm{LOH}$ \\
\hline & 190 & $\begin{array}{l}\text { HIPERPLASIA NODULAR DA } \\
\text { PARATIREOIDE COM } \\
\text { PREDOMÍNIO DE CÉLULAS } \\
\text { PRINCIPAIS } \\
\text { (paratireóide) } \\
\end{array}$ & Mutado & $\mathrm{LOH}$ \\
\hline & 198 & $\begin{array}{l}\text { HIPERPLASIA NODULAR DA } \\
\text { PARATIREOIDE COM } \\
\text { PREDOMÍNIO DE CÉLULAS } \\
\text { PRINCIPAIS } \\
\text { (paratireóide) }\end{array}$ & Mutado & $\mathrm{LOH}$ \\
\hline \multirow{2}{*}{ Individuo 17} & 195 & $\begin{array}{c}\text { CARCINOMA } \\
\text { NEUROENDÓCRINO BEM } \\
\text { DIFERENCIADO METASTÁTICO } \\
\text { EM GLÂNDULA PARATIREÓIDE } \\
\text { OU TEC PT NORMAL - } \\
\text { NEOPLASIA MEDINDO } 3,0 \mathrm{~cm}\end{array}$ & Mutado & $\mathrm{LOH}$ \\
\hline & 203 & $\begin{array}{c}\text { CARCINOMA } \\
\text { NEUROENDÓCRINO BEM } \\
\text { DIFERENCIADO METASTÁTICO } \\
\text { EM GLÂNDULA PARATIREÓIDE } \\
\text { OU TEC PT NORMAL - } \\
\text { NEOPLASIA MEDINDO } 3,0 \mathrm{~cm}\end{array}$ & Mutado & $\mathrm{LOH}$ \\
\hline \multirow{2}{*}{ Individuo 18} & 29 & Paratireóide & Mutado & $\mathrm{MOH}$ \\
\hline & 32 & Paratireóide & Mutado & $\mathrm{LOH}$ \\
\hline \multirow{5}{*}{ Individuo 19} & 53 & $\begin{array}{c}\text { HIPERPLASIA NODULAR DE } \\
\text { CÉLULAS PRINCIPAIS E } \\
\text { OXIFÍLICAS } \\
\text { Paratireóide }\end{array}$ & Mutado & $\mathrm{LOH}$ \\
\hline & 54 & $\begin{array}{c}\text { HIPERPLASIA NODULAR DE } \\
\text { CÉLULAS PRINCIPAIS E } \\
\text { OXIFÍLICAS } \\
\text { Paratireóide }\end{array}$ & Mutado & $\mathrm{LOH}$ \\
\hline & 57 & $\begin{array}{c}\text { HIPERPLASIA NODULAR DE } \\
\text { CÉLULAS PRINCIPAIS E } \\
\text { OXIFÍLICAS } \\
\text { Paratireóide }\end{array}$ & Mutado & $\mathrm{LOH}$ \\
\hline & 56 & $\begin{array}{c}\text { HIPERPLASIA NODULAR DE } \\
\text { CÉLULAS PRINCIPAIS E } \\
\text { OXIFÍLICAS } \\
\text { Paratireóide }\end{array}$ & Mutado & $\mathrm{NI}$ \\
\hline & 55 & $\begin{array}{c}\text { HIPERPLASIA NODULAR DE } \\
\text { CÉLULAS PRINCIPAIS E } \\
\text { OXIFÍLICAS } \\
\text { Paratireóide }\end{array}$ & Mutado & $\mathrm{NI}$ \\
\hline
\end{tabular}


Continuação Tabela 9

Status MEN1

\begin{tabular}{|c|c|c|c|c|}
\hline Pacientes & Tumores & Tumor & Germinativo & Somático \\
\hline \multirow{5}{*}{ Individuo 20} & 64 & $\begin{array}{c}\text { TUMOR ENDÓCRINO } \\
\text { PANCREÁTICO BEM } \\
\text { DIFERENCIADO KI-67 POSITIVO } \\
(<1 \%) \text { (sem metástase) } \\
\text { Pâncreas } \\
\end{array}$ & Mutado & $\mathrm{NI}$ \\
\hline & 65 & Pâncreas & Mutado & $\mathrm{LOH}$ \\
\hline & 66 & Pâncreas & Mutado & $\mathrm{LOH}$ \\
\hline & 68 & Pâncreas normal & Mutado & $\mathrm{LOH}$ \\
\hline & 69 & Pâncreas & Mutado & $\mathrm{LOH}$ \\
\hline \multirow{4}{*}{ Individuo 21} & 75 & adenoma (fenocópia) & $\begin{array}{l}\text { Não Mutado, } \\
\text { Fenocópia }\end{array}$ & $\mathrm{NI}$ \\
\hline & 76 & tecido normal & $\begin{array}{l}\text { Não Mutado, } \\
\text { Fenocópia }\end{array}$ & $\mathrm{NI}$ \\
\hline & 77 & Paratireóide & $\begin{array}{l}\text { Não Mutado, } \\
\text { Fenocópia }\end{array}$ & $\mathrm{NI}$ \\
\hline & 6 & ADRENAL & $\begin{array}{l}\text { Não Mutado, } \\
\text { Fenocópia }\end{array}$ & $\mathrm{NI}$ \\
\hline \multirow[t]{6}{*}{ Individuo 22} & 79 & lesão orelha & Mutado & $\mathrm{MOH}$ \\
\hline & 80 & $\begin{array}{c}\text { carcinoma epidermóide bem } \\
\text { diferenciado, invasivo } \\
\text { Lesão lábio }\end{array}$ & Mutado & $\mathrm{MOH}$ \\
\hline & 81 & $\begin{array}{c}\text { carcinoma epidermóide bem } \\
\text { diferenciado, invasivo } \\
\text { Lesão lábio } \\
\end{array}$ & Mutado & $\mathrm{MOH}$ \\
\hline & 90 & $\begin{array}{c}\text { carcinoma epidermóide bem } \\
\text { diferenciado, invasivo } \\
\text { Lesão lábio }\end{array}$ & Mutado & $\mathrm{MOH}$ \\
\hline & 82 & $\begin{array}{c}\text { carcinoma epidermóide bem } \\
\text { diferenciado, invasivo } \\
\text { lesão lobo NFDR E }\end{array}$ & Mutado & $\mathrm{MOH}$ \\
\hline & 171 & $\begin{array}{c}\text { carcinoma epidermóide bem } \\
\text { diferenciado, invasivo } \\
\text { (lobo da orelha) }\end{array}$ & Mutado & $\mathrm{MOH}$ \\
\hline \multirow{8}{*}{ Individuo 23} & 83 & $\begin{array}{c}\text { angiofibroma } \\
\text { lesão de nariz }\end{array}$ & Mutado & $\mathrm{MOH}$ \\
\hline & 84 & $\begin{array}{l}\text { angiofibroma } \\
\text { lesão de nariz }\end{array}$ & Mutado & $\mathrm{MOH}$ \\
\hline & 85 & $\begin{array}{l}\text { angiofibroma } \\
\text { lesão de nariz }\end{array}$ & Mutado & $\mathrm{MOH}$ \\
\hline & 86 & $\begin{array}{l}\text { angiofibroma } \\
\text { lesão de nariz }\end{array}$ & Mutado & $\mathrm{MOH}$ \\
\hline & 87 & $\begin{array}{l}\text { angiofibroma } \\
\text { lesão de nariz }\end{array}$ & Mutado & $\mathrm{MOH}$ \\
\hline & 88 & $\begin{array}{l}\text { colagenoma } \\
\text { lesão tórax }\end{array}$ & Mutado & $\mathrm{MOH}$ \\
\hline & 120 & HIPERPLASIA DE PARATIRÓIDE & Mutado & $\mathrm{LOH}$ \\
\hline & 135 & HIPERPLASIA DE PARATIRÓIDE & Mutado & $\mathrm{MOH}$ \\
\hline
\end{tabular}


Continuação Tabela 9

\begin{tabular}{|c|c|c|c|c|}
\hline \multirow[b]{2}{*}{ Pacientes } & \multirow[b]{2}{*}{ Tumores } & \multirow[b]{2}{*}{ Tumor } & \multicolumn{2}{|c|}{ Status MEN1 } \\
\hline & & & Germinativo & Somático \\
\hline \multirow{2}{*}{ Individuo 24} & 93 & Paratireóide & Mutado & $\mathrm{MOH}$ \\
\hline & 101 & Carcinoide & Mutado & $\mathrm{NI}$ \\
\hline \multirow{3}{*}{ Individuo 25} & 110 & lesão do tronco & $\begin{array}{l}\text { Não Mutado, } \\
\text { Fenocópia }\end{array}$ & $\begin{array}{c}\text { Controle } \\
\text { normal }\end{array}$ \\
\hline & 111 & lesão do tronco & $\begin{array}{l}\text { Não Mutado, } \\
\text { Fenocópia }\end{array}$ & $\begin{array}{c}\text { Controle } \\
\text { normal }\end{array}$ \\
\hline & 112 & lesão do tronco & $\begin{array}{l}\text { Não Mutado, } \\
\text { Fenocópia }\end{array}$ & $\begin{array}{c}\text { Controle } \\
\text { normal }\end{array}$ \\
\hline \multirow[t]{2}{*}{ Individuo 26} & 124 & $\begin{array}{l}\text { HIPERPLASIA DIFUSA DE } \\
\text { CÉLULAS PRINCIPAIS E } \\
\text { OXIFÍLICAS } \\
\end{array}$ & Mutado & $\mathrm{LOH}$ \\
\hline & 136 & Colagenoma & Mutado & $\mathrm{LOH}$ \\
\hline \multirow{2}{*}{ Individuo 27} & 127 & Paratireóide & Mutado & $\mathrm{LOH}$ \\
\hline & 129 & Paratireóide & Mutado & $\mathrm{LOH}$ \\
\hline Individuo 28 & 144 & $\begin{array}{c}\text { HIPERPLASIA NODULAR E } \\
\text { DIFUSA DE CÉLULAS } \\
\text { PRINCIPAIS (PREDOMINANTE) E } \\
\text { OXIFÍLICAS }\end{array}$ & Mutado & $\mathrm{MOH}$ \\
\hline \multirow{2}{*}{ Individuo 29} & 156 & $\begin{array}{l}\text { PARATIREÓIDE NORMAL } \\
\text { PROVÁVEL }\end{array}$ & Mutado & $\mathrm{NI}$ \\
\hline & 157 & $\begin{array}{l}\text { PARATIREÓIDE NORMAL } \\
\text { PROVÁVEL }\end{array}$ & Mutado & $\mathrm{MOH}$ \\
\hline \multirow[t]{6}{*}{ Individuo 30} & 160 & $\begin{array}{l}\text { adenoma hipofisário não- } \\
\text { funcionante }\end{array}$ & Mutado & $\mathrm{LOH}$ \\
\hline & 161 & 38146 & Mutado & $\mathrm{LOH}$ \\
\hline & 212 & $\begin{array}{l}\text { adenoma hipofisário não- } \\
\text { funcionante }\end{array}$ & Mutado & $\mathrm{LOH}$ \\
\hline & 148 & $\begin{array}{l}\text { adenoma hipofisário não- } \\
\text { funcionante }\end{array}$ & Mutado & $\mathrm{LOH}$ \\
\hline & 173 & $\begin{array}{c}\text { adenoma hipofisário não- } \\
\text { funcionante }\end{array}$ & Mutado & $\mathrm{LOH}$ \\
\hline & 163 & ADENOMA DE PARATIREÓIDE; & Mutado & $\mathrm{LOH}$ \\
\hline \multirow[t]{4}{*}{ Individuo 31} & 164 & 38976 & Mutado & $\mathrm{LOH}$ \\
\hline & 165 & ADENOMA DE PARATIREÓIDE; & Mutado & $\mathrm{LOH}$ \\
\hline & 40 & Carcinoide & Mutado & $\mathrm{NI}$ \\
\hline & 41 & Carcinoide & Mutado & $\mathrm{NI}$ \\
\hline \multirow[t]{3}{*}{ Individuo 32} & 42 & Carcinoide & Mutado & $\mathrm{LOH}$ \\
\hline & 42 & Carcinoide & Mutado & $\mathrm{LOH}$ \\
\hline & 43 & Carcinóide & Mutado & $\mathrm{LOH}$ \\
\hline
\end{tabular}

Continua... 
Conclusão Tabela 9

\section{Status MEN1}

\begin{tabular}{|c|c|c|c|c|}
\hline Pacientes & Tumores & Tumor & Germinativo & Somático \\
\hline Individuo 33 & 199 & $\begin{array}{c}\text { Paratireóide } \\
\text { SEM ALTERAÇÕES } \\
\text { HISTOLÓGICAS SIGNIFICATIVAS }\end{array}$ & $\begin{array}{c}\text { Não Mutado ao } \\
\text { Seq }\end{array}$ & $\mathrm{NI}$ \\
\hline Individuo 34 & 193 & $\begin{array}{c}\text { hiperplasia difusa e nodular de } \\
\text { células principais e oxifílicas } \\
\text { Paratireóide }\end{array}$ & Mutado & $\mathrm{NI}$ \\
\hline Individuo 35 & 209 & $\begin{array}{c}\text { HIPERPLASIA NODULAR DE } \\
\text { CÉLULAS PRINCIPAIS E } \\
\text { OXIFÍLICAS }\end{array}$ & Mutado & $\mathrm{NI}$ \\
\hline \multirow{2}{*}{ Individuo 36} & 196 & Duodeno & Mutado & $\mathrm{NI}$ \\
\hline & 200 & Pâncreas & Mutado & $\mathrm{NI}$ \\
\hline Individuo 37 & 197 & $\begin{array}{l}\text { hiperplasia } \\
\text { Paratireóide }\end{array}$ & Mutado & $\mathrm{NI}$ \\
\hline \multirow{2}{*}{ Individuo 38} & 192 & $\begin{array}{l}\text { hiperplasia } \\
\text { Paratireóide }\end{array}$ & Mutado & $\mathrm{NI}$ \\
\hline & 202 & $\begin{array}{l}\text { hiperplasia } \\
\text { Paratireóide }\end{array}$ & Mutado & $\mathrm{NI}$ \\
\hline
\end{tabular}

Tabela 10: Resumo dos achados do status somático do gene MEN1 em tumores NEM1

\begin{tabular}{cccccccc}
\hline & HPT & Panc/Duodeno & Hipófise & Carcinóide & ACT & Pele & $\begin{array}{c}\text { Em revisão de } \\
\text { lamina }\end{array}$ \\
\hline LOH & $40 / 53$ & $11 / 18$ & $1 / 1$ & $12 / 13$ & $0 / 4$ & $4 / 19$ & $7 / 8$ \\
MOH & $13 / 53$ & $7 / 18$ & $0 / 1$ & $1 / 13$ & $4 / 4$ & $15 / 19$ & $1 / 8$ \\
$\%$ de LOH & $75,40 \%$ & $61,10 \%$ & $100 \%$ & $93 \%$ & $0 \%$ & $21 \%$ & $/$ \\
\hline
\end{tabular}

$\mathrm{LOH}=$ perda de heterozigose; $\mathrm{MOH}=$ manutenção de heterosigose 

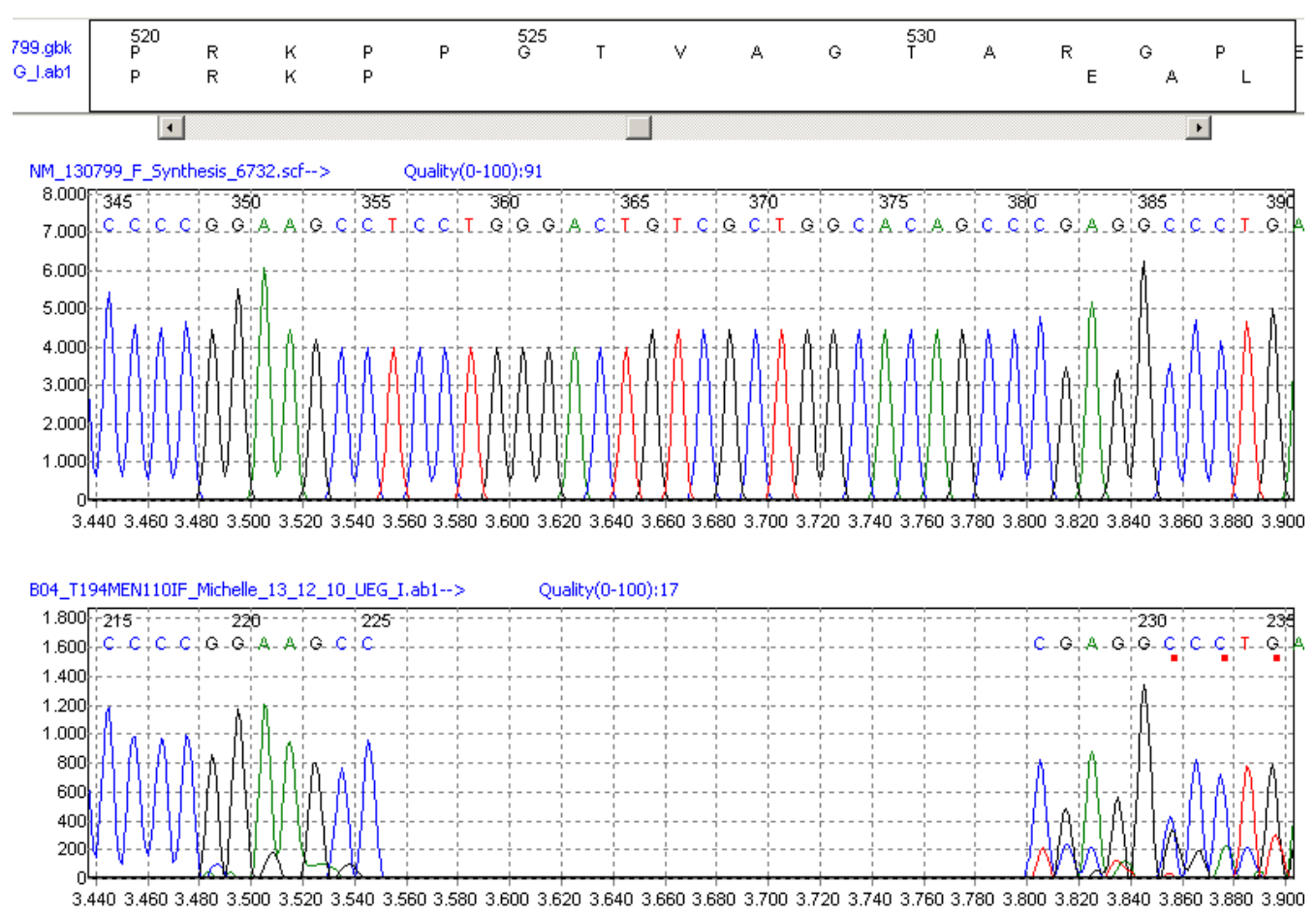

Figura 12: O eletroferogramada acima mostra a sequencia controle do gene MEN1 e abaixo a sequencia do tumor, com clara evidencia de LOH no tumor 194 (paratireóide), de paciente com mutação germinativa com deleção de 25 pb
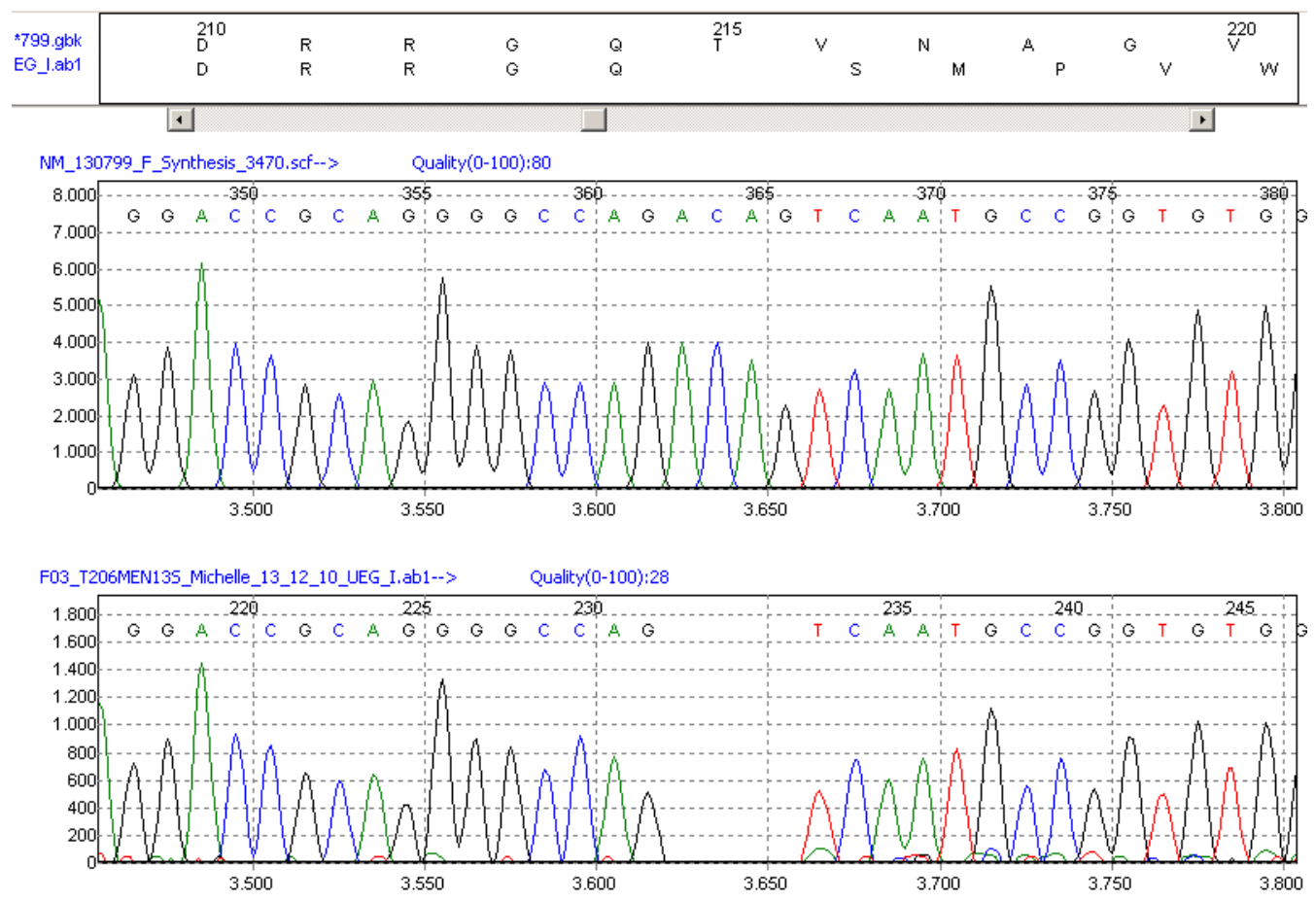

Figura 13: O eletroferogramada acima mostra a sequencia controle do gene MEN1 e abaixo a sequencia do tumor, com clara evidencia de LOH no tumor 206 (pâncreas) , de paciente com mutação germinativa com deleção de 4 pb 

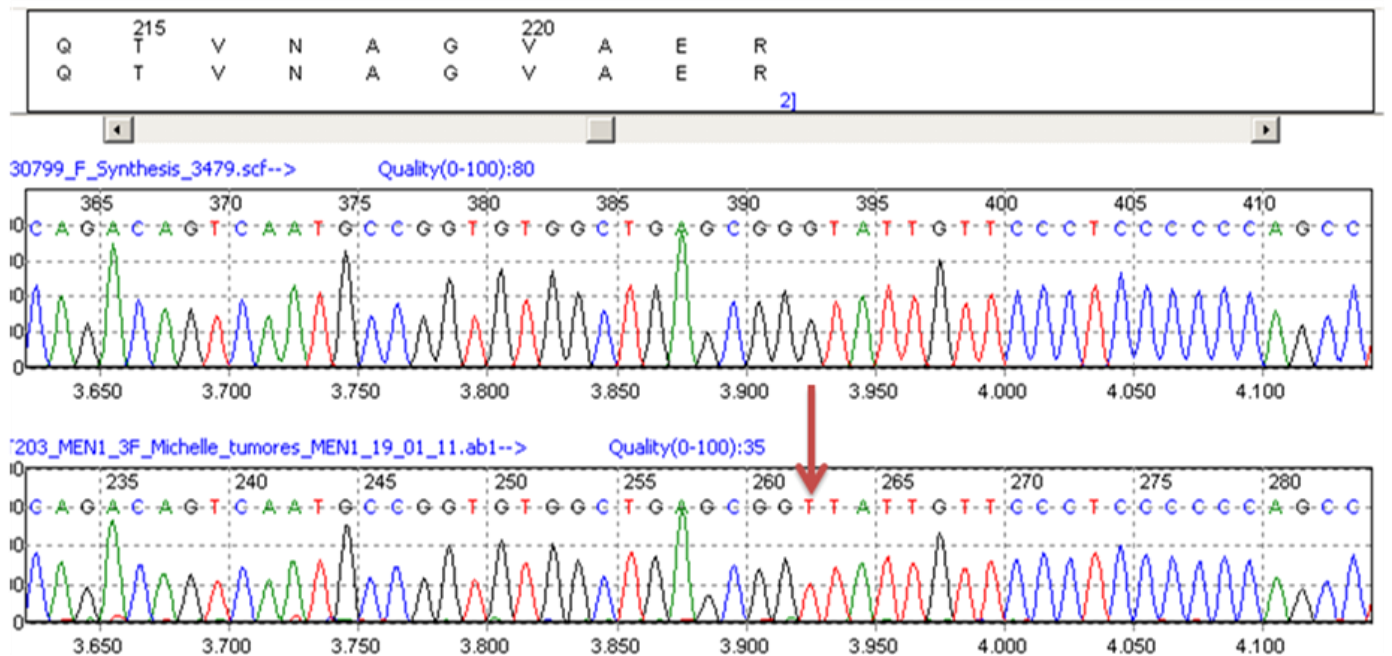

Figura 14: O eletroferogramada acima mostra a sequencia controle do gene MEN1 e abaixo a sequencia do tumor, com clara evidencia de LOH no tumor 203 (paratireóide), de paciente com mutação germinativa IVS3+1G>T

\subsection{Análise de LOH por marcadores de microssatélites}

\subsubsection{Polimorfismo intragênico D418D}

O polimorfismo D418D (rs2071313), localizado no éxon 9 do gene MEN1 também foi estudado. Esse é um polimorfismo que pode apresentar os alelos C (GAC) e T (GAT), sem que ocorra troca de aminoácido $($ aspartato $=$ D) $($ Tabela 11$)$.

\subsubsection{Sangue}

Três pacientes possuíam o genótipo $\mathrm{C} / \mathrm{T}$ no sangue e, portanto, esse marcador foi informativo para esses casos. Os demais pacientes possuíam o genótipo $\mathrm{C} / \mathrm{C}$ no sangue, portanto, esse marcador não foi informativo para esses demais pacientes Figuras (15,16 e 17). 
Genótipo C/T (D418D, sangue)

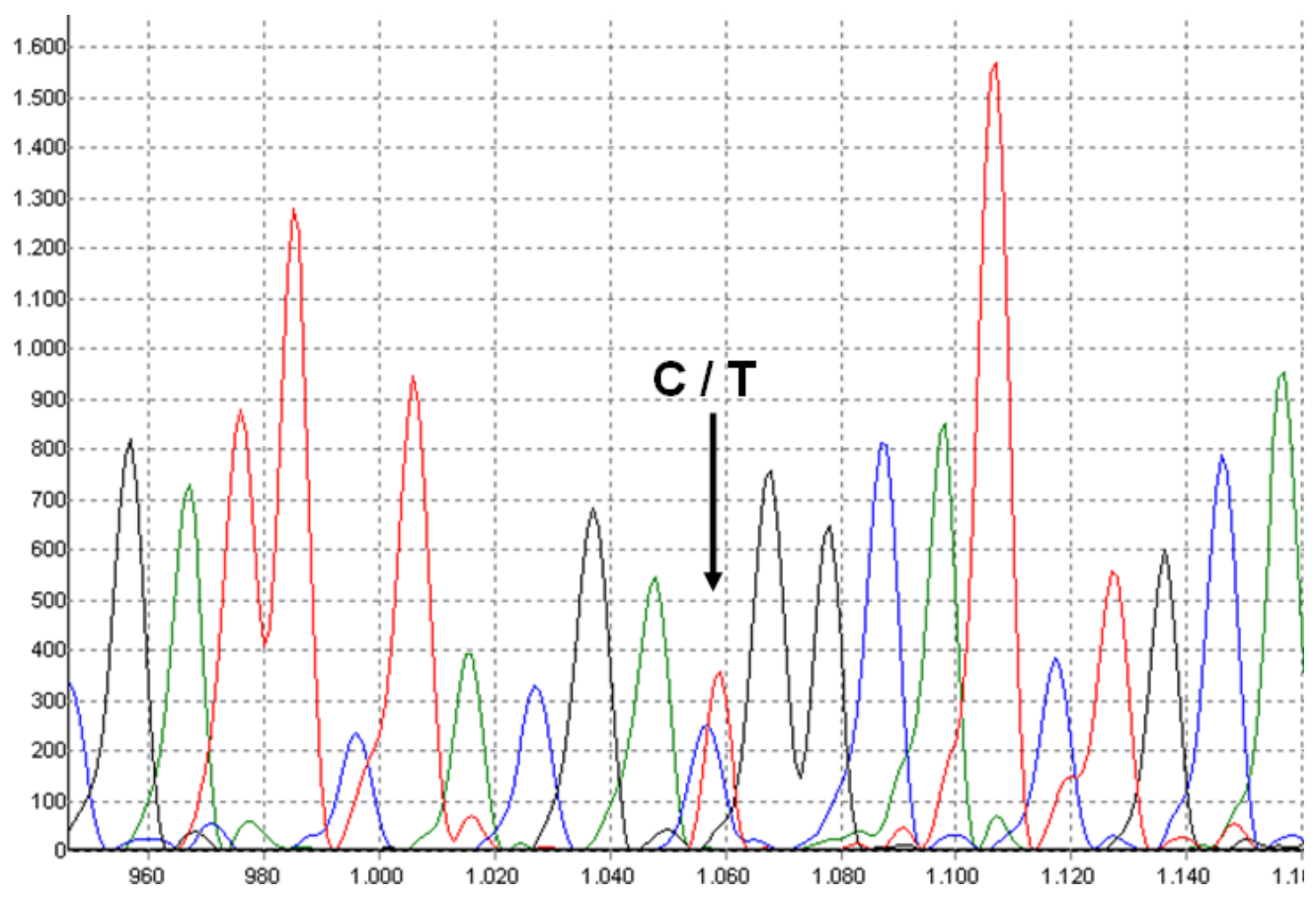

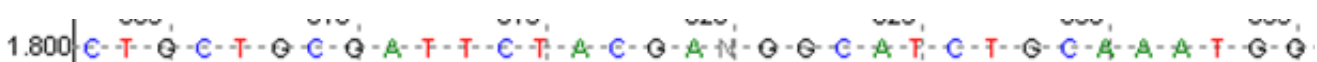

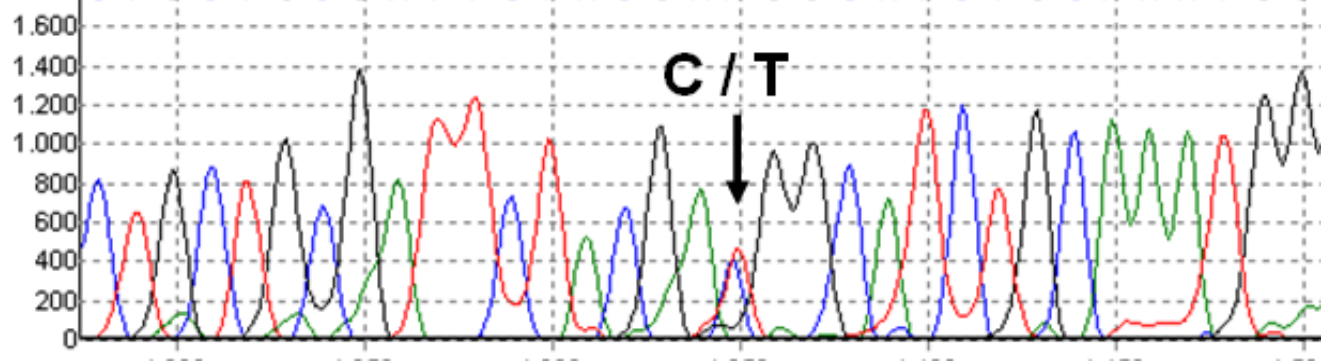

Genótipo C/C (D418D, sangue)

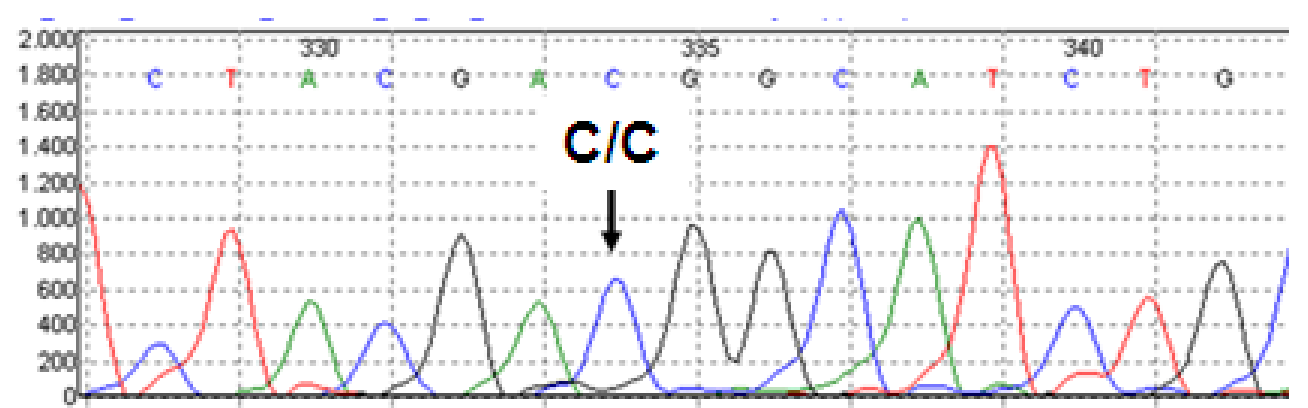

Figuras 15,16 e 17 : Genotipagem do polimorfismo D418D, localizado no éxon 9 do gene MEN1, nas amostras de DNA de leucócitos de pacientes com NEM1. Foram identificados os alelos C e T e os genótipos CC e CT 


\subsubsection{Adenoma de paratireóide e tumor de pâncreas}

Dentre os três pacientes que tinham os alelos $\mathrm{C} / \mathrm{T}$ para o polimorfismo D418D, pudemos observar perda do alelo normal (T) em dois tumores estudados: adenoma de paratireóide e tumor pancreático secretor de insulina (insulinoma), conforme podemos observar nas figuras abaixo (Figuras 18 e 19).

Genótipo C/LOH (D418D, adenoma de paratireóide)

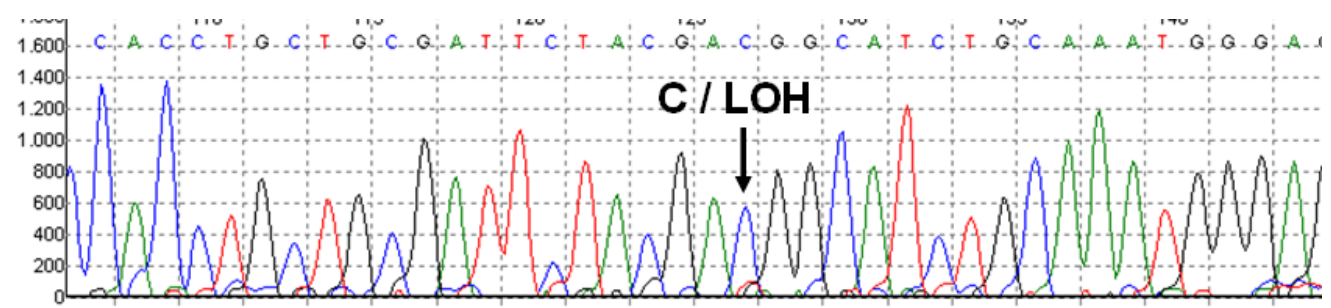

Genótipo C/LOH (D418D, insulinoma)

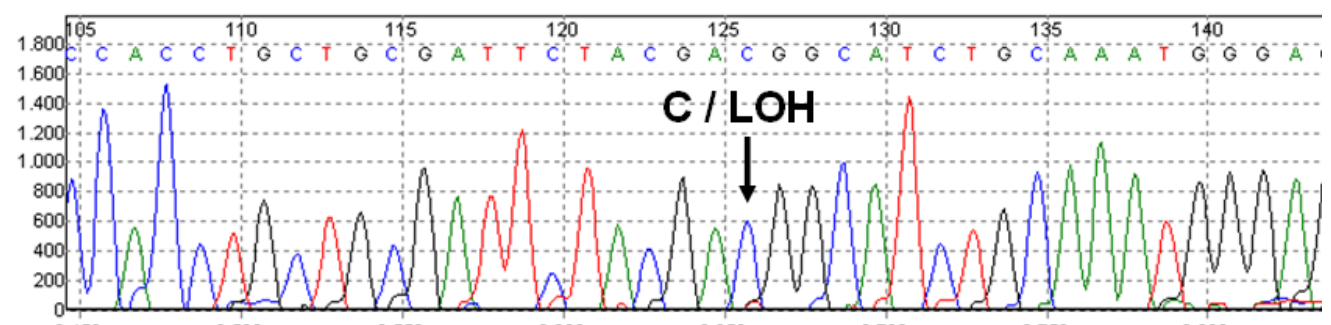

Figuras 18 e 19: A genotipagem do polimorfismo D418D mostrou perda do alelo $T$ no DNA do tumor, evidenciando perda do alelo normal do gene MEN1 nas células tumorais

Esses resultados apontam para a ocorrência de um evento genético somático (nos tecidos) nesses tumores de paratireóide e pâncreas. Como esses pacientes já possuíam uma mutação no sangue, esse segundo evento somático $(\mathrm{LOH})$ levou à inativação completa do gene MEN1, que leva a uma ausência da síntese da proteína supressora de tumor MENIN nessas células, causando uma proliferação celular descontrolada e formação do tumor. 


\subsubsection{Angiofibroma}

Já as células do tumor de pele analisado (angiofibroma) possuíam os alelos $\mathrm{C}$ e $\mathrm{T}$, exatamente igual no sangue. Isso indica que não houve inativação do gene MEN1 nesse tumor e sugere que a causa da tumorigenese desse angiofibroma pode ser outra, que não a ausência da proteína MENIN (Figura 20).

Genótipo C/T (D418D, angiofibroma)

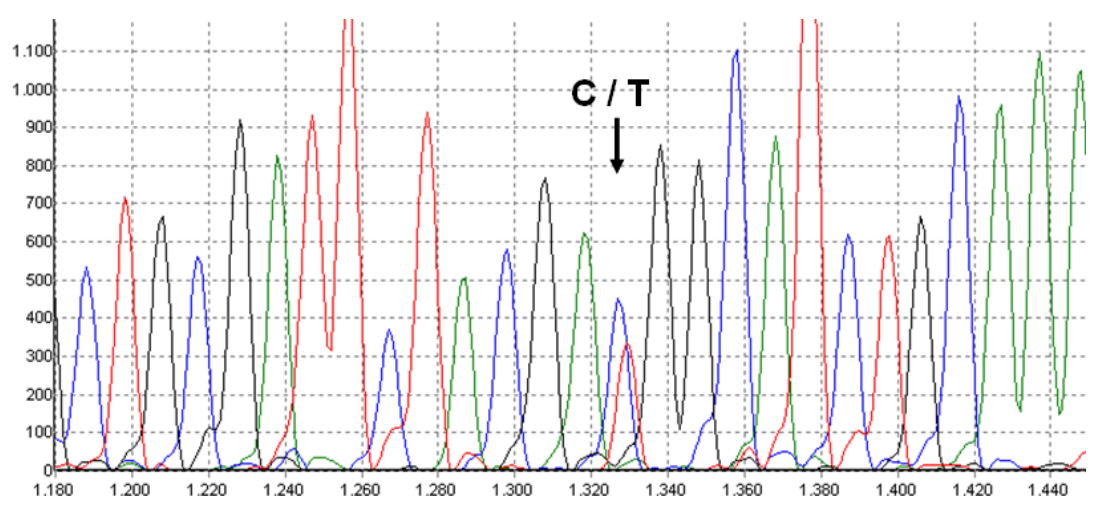

Figura 20: A genotipagem do polimorfismo D418D nas células do tumor angiofibroma revelou o genótipo $\mathrm{C} / \mathrm{T}$, indicando manutenção de heterozigose 
Tabela 11: Resultados da genotipagem do polimorfismo intragênico D418D nas células de leucócitos e de tumores de pacientes com NEM1. Dois alelos foram identificados C e T e dois genótipos CC e CT. Em negrito estão as analises que demonstraram perda de heterozigose $(\mathrm{LOH})$ ou manutenção de heterozigose $(\mathrm{MH})$

\begin{tabular}{|c|c|c|c|c|c|c|c|c|}
\hline \multicolumn{9}{|c|}{ Polimorfismo D418D (SNP do éxon 9 do gene MEN1) } \\
\hline Pacientes & Sangue & glândula 1 & tumor & glândula 2 & tumor & glândula 3 & Tumor & Resultado \\
\hline Indivíduo 1 & GAC/GAT & $\begin{array}{l}\text { Paratireóide } \\
\text { (PTSE) }\end{array}$ & GAC/GAC & & & & & LOH \\
\hline Indivíduo 2 & GAC/GAT & $\begin{array}{c}\text { Insulinoma } \\
\text { (Tecido. Pâncreas) }\end{array}$ & GAC/GAC & & & & & LOH \\
\hline Indivíduo 3 & GAC/GAT & $\begin{array}{l}\text { Angiofibroma } \\
\text { (Barriga) }\end{array}$ & GAC/GAT & & & & & MH \\
\hline Indivíduo 4 & GAC GAC & $\begin{array}{l}\text { Gastrinoma } \\
\text { (Duodeno) }\end{array}$ & GAC/GAC & & & & & homozigose \\
\hline Indivíduo 5 & GAC/GAC & $\begin{array}{l}\text { Hiperplasia da Adrenal } \\
\text { Não funcionante } \\
\text { (Adrenal) }\end{array}$ & GAC/GAC & Tu.carc. Pulmão & GAC/GAC & & & homozigose \\
\hline Indivíduo 6 & GAC/GAC & $\begin{array}{l}\text { Colagenoma } \\
\text { (Tórax posterior } \\
\text { superior) }\end{array}$ & GAC/GAC & & & & & homozigose \\
\hline Indivíduo 7 & $\mathrm{GAC} / \mathrm{GAC}$ & $\begin{array}{l}\text { Carcinoma } \\
\text { epidermoide bem } \\
\text { diferenciado } \\
\text { Invasivo } \\
\text { (Tecido orelha) }\end{array}$ & GAC/GAC & $\begin{array}{l}\text { Carcinoma } \\
\text { epidermoide bem } \\
\text { diferenciado } \\
\text { invasivo } \\
\text { (Lábio) }\end{array}$ & GAC/GAC & NF DRE & & homozigose \\
\hline
\end{tabular}


Conclusão da Tabela 7.

Polimorfismo D418D (SNP do éxon 9 do gene MEN1)

\begin{tabular}{|c|c|c|c|c|c|c|c|c|}
\hline Pacientes & Sangue & glândula 1 & tumor & glândula 2 & tumor & glândula 3 & Tumor & Resultado \\
\hline Indivíduo 8 & GAC/GAC & $\begin{array}{c}\text { Paratireóide } \\
\text { (Anterior Superior) }\end{array}$ & GAC/GAC & & & & & homozigose \\
\hline Indivíduo 9 & GAC/GAC & $\begin{array}{l}\text { Paratireóide } \\
\text { (PTIE) }\end{array}$ & GAC/GAC & & & & & homozigose \\
\hline Indivíduo10 & GAC/GAC & $\begin{array}{c}\text { Angiofibroma } \\
\text { inflamado } \\
\text { (Nariz) }\end{array}$ & GAC/GAC & $\begin{array}{c}\text { Colagenoma } \\
\text { (Pele tórax } \\
\text { posterior } \\
\text { Esquerdo) }\end{array}$ & GAC/GAC & $\begin{array}{c}\text { amostra } 2 \\
\text { nariz }\end{array}$ & & homozigose \\
\hline Indivíduo11 & & $\begin{array}{l}\text { reg. Dorsal do tronco } \\
\text { ant sup } D\end{array}$ & GAC/GAC & & & & & homozigose \\
\hline Indivíduo12 & & Paratireóide. Adenoma & GAC/GAC & & & & & homozigose \\
\hline
\end{tabular}




\subsubsection{Análise de LOH com o marcador de microssatélite PYGM}

Em uma segunda fase, iniciamos a genotipagem de um segundo marcador, o PYGM. Este marcador de microssatélite é caracterizado por ser polimórfico e para estudá-lo, desenhamos um dos primers para sua amplificação com fluorescência incorporada, para assim ser lido em seqüenciador automático.

Os indivíduos que eram não-informativos para o polimorfismo D418D, por possuírem os alelos C-C no sangue, foram então genotipados para o marcador PYGM (Tabela 12).

Quatro indivíduos estavam em heterozigose no sangue (alelos 319335) o que nos possibilitou a comparação com o genótipo obtido dos DNAs dos tumores. Pudemos observar um segundo evento mutacional (perda do alelo 319) nos seguintes tumores: colagenoma, carcinoma epidermóide bem diferenciado invasivo e dois adenomas/hiperplasias de paratireóides. 
Tabela 12: Resultados de análises de DNA leucocitário e tecidos de pacientes com NEM1 através do marcador de microssatelite PYGM. Em negrito as análises que mostraram perda alélica, ou seja, inativação do gene MEN1

\begin{tabular}{|c|c|c|c|c|c|c|c|c|}
\hline \multicolumn{9}{|c|}{ Marcador de microssatélite PYGM } \\
\hline Pacientes & Sangue & glândula 1 & tumor & glândula 2 & tumor & glândula 3 & tumor & Resultado \\
\hline Individuo 6 & $319 / 335$ & $\begin{array}{c}\text { Colagenoma } \\
\text { (Tórax posterior } \\
\text { superior) }\end{array}$ & 335/LOH & & & & & LOH \\
\hline Individuo7 & $319 / 335$ & $\begin{array}{l}\text { Carcinoma } \\
\text { epidermóide bem } \\
\text { diferenciado } \\
\text { Invasivo } \\
\text { (Tecido orelha ) }\end{array}$ & & $\begin{array}{c}\text { Carcinoma } \\
\text { epidermóide } \\
\text { bem } \\
\text { diferenciado } \\
\text { invasivo } \\
\text { (Lábio) }\end{array}$ & 335/LOH & & & LOH \\
\hline Individuo 8 & $319 / 335$ & $\begin{array}{c}\text { Paratireóide } \\
\text { (Anterior Superior) }\end{array}$ & 335/LOH & & & & & LOH \\
\hline Individuo 9 & $319 / 335$ & Paratireóide (PTIE) & 335/LOH & $\begin{array}{l}\text { Paratireóide } \\
\text { (PTSD) }\end{array}$ & 335/LOH & & & LOH \\
\hline Individuo 10 & $\mathrm{NI}$ & $\begin{array}{l}\text { Angiofibroma } \\
\text { inflamado } \\
\text { (Nariz) }\end{array}$ & $\mathrm{NI}$ & $\begin{array}{l}\text { Colagenoma } \\
\text { (Pele tórax } \\
\text { posterior } \\
\text { Esquerdo) }\end{array}$ & $\mathrm{NI}$ & & & Homozigose \\
\hline Individuo 12 & $\mathrm{NI}$ & Parat normal E & $\mathrm{NI}$ & Adenoma & $\mathrm{NI}$ & & & Homonigose \\
\hline
\end{tabular}




\subsection{Análise de mutação somática do gene p27Kip1 em tumores NEM1}

Nenhuma variante patogênica (mutação) foi identificada em 94 amostras cuja região codificadora (éxons 1 e 2) foi interamente sequenciada.

\subsubsection{Análise de LOH no gene p27Kip1 em tumores NEM1}

Os polimorfismos previamente descritos c.-79C>T, rs34330 (localizado na região 5' UTR) e o c.326T>G, p.V109G, rs2066827 (localizado no éxon 1) foram identificados e usados como marcadores de heterozigose nesses tumores.

Cento e três tumores NEM1 foram analisados para LOH-p27Kip1 através de sequenciamento do SNP V109G. Destes, 46 não foram informativos, pois sangue e tumor apresentavam mesmo genótipo em homozigose (GG ou TT); 52 tumores apresentavam evidências de manutenção de heterozigose (GT no sangue e GT no tumor), e 5 tumores apresentavam evidências de LOH (GT no sangue e_t no tumor) (Tabela 13). 
Tabela 13: Análise do status somático do gene p27Kip1

\begin{tabular}{|c|c|c|c|c|c|c|c|c|}
\hline \multirow[t]{2}{*}{ Paciente } & \multirow[t]{2}{*}{ amostra } & \multirow[t]{2}{*}{ Tumor } & \multirow{2}{*}{$\begin{array}{c}\text { p27 } \\
\text { germinativo } \\
\text { V109G }\end{array}$} & \multicolumn{3}{|c|}{ p27 somático Ex.1 } & \multirow{2}{*}{$\begin{array}{c}\text { p27 } \\
\text { somático } \\
\text { Ex.2 }\end{array}$} & \multirow{2}{*}{$\begin{array}{l}\text { Mutação somática p27 } \\
\text { Mutação somática p27 } \\
\text { na região codificadora }\end{array}$} \\
\hline & & & & p.V109G & p27 - LOH & c. -79 & & \\
\hline \multirow[t]{4}{*}{ Individuo 1} & 1 & $\begin{array}{l}\text { hiperplasia } \\
\text { Paratireóide }\end{array}$ & \multirow[t]{2}{*}{ TT } & $\mathrm{TT}$ & $\mathrm{NI}$ & - & NL & SEM MUTAÇÃO \\
\hline & 2 & $\begin{array}{l}\text { hiperplasia } \\
\text { Paratireóide }\end{array}$ & & TT & $\mathrm{NI}$ & - & NL & SEM MUTAÇÃO \\
\hline & 3 & $\begin{array}{l}\text { hiperplasia } \\
\text { Paratireóide }\end{array}$ & & TT & $\mathrm{NI}$ & - & NL & SEM MUTAÇÃO \\
\hline & 138 & Lesão sem identificação & & TT & $\mathrm{NI}$ & - & $\mathrm{NL}$ & SEM MUTAÇÃO \\
\hline \multirow{3}{*}{ Individuo 2} & 149 & Paratireóide & \multirow{3}{*}{ TT } & TT & $\mathrm{NI}$ & $\mathrm{CC}$ & $\mathrm{NL}$ & SEM MUTAÇÃO \\
\hline & 5 & Lesão de Tronco & & TT & $\mathrm{NI}$ & - & $\mathrm{NL}$ & SEM MUTAÇÃO \\
\hline & 169 & Lesão naraiz & & TT & $\mathrm{NI}$ & $\mathrm{CC}$ & $\mathrm{NL}$ & SEM MUTAÇÃO \\
\hline \multirow{2}{*}{ Individuo3 } & 7 & Paratireóide & \multirow{2}{*}{ GT } & GT & $\mathrm{MOH}$ & $\mathrm{CC}$ & $\mathrm{NL}$ & SEM MUTAÇÃO \\
\hline & 8 & Paratireóide & & GT & $\mathrm{MOH}$ & CC & $\mathrm{NL}$ & SEM MUTAÇÃO \\
\hline \multirow{3}{*}{ Individuo 4} & 11 & $\begin{array}{c}\text { colagenoma } \\
\text { Lesão de Tronco }\end{array}$ & \multirow{3}{*}{ GT } & - & - & $\mathrm{CT}$ & - & $\mathrm{NI}$ \\
\hline & 13 & $\begin{array}{c}\text { colagenoma } \\
\text { Lesão de Tronco }\end{array}$ & & - & - & - & - & $\mathrm{NI}$ \\
\hline & 15 & $\begin{array}{c}\text { colagenoma } \\
\text { Lesão de Tronco }\end{array}$ & & GT & $\mathrm{MOH}$ & - & NL & SEM MUTAÇÃO \\
\hline \multirow{6}{*}{ Individuo 5} & 16 & Paratireóide & \multirow{6}{*}{ GT } & GT & $\mathrm{MOH}$ & CT & $\mathrm{NL}$ & SEM MUTAÇÃO \\
\hline & 17 & Paratireóide & & $/ T$ & $\mathrm{LOH}$ & CT & $\mathrm{NL}$ & $\mathrm{LOH} / \mathrm{T}$ \\
\hline & 18 & Paratireóide & & GT & $\mathrm{MOH}$ & $\mathrm{CT}$ & $\mathrm{NL}$ & SEM MUTAÇÃO \\
\hline & 19 & Paratireóide & & GT & $\mathrm{MOH}$ & CT & $\mathrm{NL}$ & SEM MUTAÇÃO \\
\hline & 20 & Paratireóide & & GT & $\mathrm{MOH}$ & CT & $\mathrm{NL}$ & SEM MUTAÇÃO \\
\hline & 21 & Paratireóide & & GT & $\mathrm{MOH}$ & CT & $\mathrm{NL}$ & SEM MUTAÇÃO \\
\hline
\end{tabular}


Continuação da Tabela 13.

\begin{tabular}{|c|c|c|c|c|c|c|c|c|}
\hline \multirow[t]{2}{*}{ Paciente } & \multirow{2}{*}{$\begin{array}{c}\text { amostra } \\
22 \\
\end{array}$} & \multirow{2}{*}{$\begin{array}{c}\text { Tumor } \\
\text { Paratireóide } \\
\end{array}$} & \multirow[t]{2}{*}{$\begin{array}{c}\text { p27 } \\
\text { germinativo } \\
\text { V109G }\end{array}$} & \multicolumn{3}{|c|}{ p27 somático Ex.1 } & \multirow{2}{*}{$\begin{array}{c}\begin{array}{c}\text { p27 } \\
\text { somático } \\
\text { Ex.2 }\end{array} \\
\mathrm{NL} \\
\end{array}$} & \multirow{2}{*}{$\begin{array}{c}\text { Mutação somática p27 } \\
\text { SEM MUTAÇÃO } \\
\end{array}$} \\
\hline & & & & TT & $\mathrm{NI}$ & $\mathrm{CC}$ & & \\
\hline \multirow{9}{*}{ Individuo 6} & 23 & Paratireóide & \multirow{9}{*}{ TT } & TT & $\mathrm{NI}$ & - & $\mathrm{NL}$ & SEM MUTAÇÃO \\
\hline & 24 & Paratireóide & & TT & $\mathrm{NI}$ & - & NL & SEM MUTAÇÃO \\
\hline & 26 & Paratireóide & & - & - & - & $\mathrm{NL}$ & $\mathrm{NI}$ \\
\hline & 27 & Paratireóide & & TT & $\mathrm{NI}$ & $\mathrm{CC}$ & $\mathrm{NL}$ & SEM MUTAÇÃO \\
\hline & 28 & Paratireóide & & TT & $\mathrm{NI}$ & - & $\mathrm{NL}$ & SEM MUTAÇÃO \\
\hline & 30 & Paratireóide & & TT & $\mathrm{NI}$ & - & NL & SEM MUTAÇÃO \\
\hline & 31 & Paratireóide & & TT & $\mathrm{NI}$ & - & $\mathrm{NL}$ & SEM MUTAÇÃO \\
\hline & 33 & Paratireóide & & TT & $\mathrm{NI}$ & $\mathrm{CC}$ & $\mathrm{NL}$ & SEM MUTAÇÃO \\
\hline & 34 & Paratireóide & & TT & $\mathrm{NI}$ & $\mathrm{CC}$ & $\mathrm{NL}$ & SEM MUTAÇÃO \\
\hline \multirow{7}{*}{ Individuo7 } & 44 & $\begin{array}{l}\text { Gastrinoma } \\
\text { Duodeno }\end{array}$ & \multirow{7}{*}{ TT } & TT & $\mathrm{NI}$ & - & $\mathrm{NL}$ & SEM MUTAÇÃO \\
\hline & 49 & $\begin{array}{l}\text { TNE pancreático não } \\
\text { funcionante KI67> 2\% }\end{array}$ & & TT & $\mathrm{NI}$ & TT & NL & SEM MUTAÇÃO \\
\hline & 51 & $\begin{array}{l}\text { TNE pancreático não } \\
\text { funcionante KI67> 2\% }\end{array}$ & & TT & $\mathrm{NI}$ & TT & $\mathrm{NL}$ & SEM MUTAÇÃO \\
\hline & 52 & $\begin{array}{l}\text { TNE pancreático não } \\
\text { funcionante KI67> 2\% }\end{array}$ & & TT & $\mathrm{NI}$ & TT & $\mathrm{NL}$ & SEM MUTAÇÃO \\
\hline & 132 & Paratireóide & & - & - & - & - & $\mathrm{NI}$ \\
\hline & 47 & $\begin{array}{l}\text { TNE pancreático não } \\
\text { funcionante KI67> 2\% }\end{array}$ & & TT & $\mathrm{NI}$ & TT & $\mathrm{NL}$ & SEM MUTAÇÃO \\
\hline & 48 & $\begin{array}{l}\text { TNE pancreático não } \\
\text { funcionante KI67> 2\% }\end{array}$ & & TT & $\mathrm{NI}$ & TT & $\mathrm{NL}$ & SEM MUTAÇÃO \\
\hline
\end{tabular}


Continuação da Tabela 13.

\begin{tabular}{|c|c|c|c|c|c|c|c|c|}
\hline \multirow[t]{4}{*}{ Paciente } & \multirow{2}{*}{$\begin{array}{c}\text { amostra } \\
50\end{array}$} & \multirow{2}{*}{$\begin{array}{c}\text { Tumor } \\
\text { TNE pancreático não } \\
\text { funcionante KI67> 2\% }\end{array}$} & \multirow{2}{*}{$\begin{array}{c}\text { p27 } \\
\text { germinativo } \\
\text { V109G }\end{array}$} & \multicolumn{3}{|c|}{ p27 somático Ex.1 } & \multirow{2}{*}{$\begin{array}{c}\begin{array}{c}\text { p27 } \\
\text { somático } \\
\text { Ex.2 }\end{array} \\
\mathrm{NL}\end{array}$} & \multirow{2}{*}{$\begin{array}{c}\text { Mutação somática p27 } \\
\text { SEM MUTAÇÃO }\end{array}$} \\
\hline & & & & TT & $\mathrm{NI}$ & TT & & \\
\hline & 117 & $\begin{array}{l}\text { Hiperplasia } \\
\text { Paratireóide }\end{array}$ & & $\mathrm{TT}$ & $\mathrm{NI}$ & - & NL & SEM MUTAÇÃO \\
\hline & 49 & Pâncreas & & TT & $\mathrm{NI}$ & TT & $\mathrm{NL}$ & SEM MUTAÇÃO \\
\hline \multirow{2}{*}{ Individuo 8} & 58 & Paratireóide & \multirow{2}{*}{ TT } & TT & $\mathrm{NI}$ & CT & $\mathrm{NL}$ & SEM MUTAÇÃO \\
\hline & 59 & Paratireóide & & TT & $\mathrm{NI}$ & CT & $\mathrm{NL}$ & SEM MUTAÇÃO \\
\hline \multirow[t]{3}{*}{ Individuo 9} & 61 & $\begin{array}{c}\text { colagenoma } \\
\text { Lesão Barriga }\end{array}$ & TT & $\mathrm{TT}$ & $\mathrm{NI}$ & - & NL & SEM MUTAÇÃO \\
\hline & 62 & $\begin{array}{c}\text { colagenoma } \\
\text { Lesão Barriga }\end{array}$ & & TT & $\mathrm{NI}$ & - & NL & SEM MUTAÇÃO \\
\hline & 63 & $\begin{array}{l}\text { tNE pancreático não } \\
\text { funcionante ou } \\
\text { insulinoma, sem } \\
\text { metástase local }\end{array}$ & & - & - & - & NL & $\mathrm{NI}$ \\
\hline \multirow[t]{2}{*}{ Individuo 10} & 70 & $\begin{array}{c}\text { hiperplasia } \\
\text { Paratireóide }\end{array}$ & $\begin{array}{l}\text { 109-TT, E75D- } \\
\mathrm{Aa}\end{array}$ & $\begin{array}{l}\text { 109-TT, } \\
\text { E75D-Aa }\end{array}$ & $\mathrm{NI}$ & - & NL & SEM MUTAÇÃO \\
\hline & 71 & $\begin{array}{l}\text { hiperplasia } \\
\text { Paratireóide }\end{array}$ & & $\begin{array}{l}\text { 109-TT, } \\
\text { E75D-Aa }\end{array}$ & $\mathrm{NI}$ & - & - & $\mathrm{NI}$ \\
\hline \multirow{4}{*}{ Individuo11 } & 91 & $\begin{array}{c}\text { hiperplasia } \\
\text { Adrenal }\end{array}$ & \multirow{4}{*}{ GT } & GT & $\mathrm{MOH}$ & - & NL & SEM MUTAÇÃO \\
\hline & 92 & $\begin{array}{c}\text { carcinóide brônquico com } \\
\text { metástase }\end{array}$ & & GT & $\mathrm{MOH}$ & - & NL & SEM MUTAÇÃO \\
\hline & 94 & Paratireóide & & $-1 \mathrm{~T}$ & $\mathrm{LOH}$ & - & NL & $\mathrm{LOH} / \mathrm{T}$ \\
\hline & 95 & $\begin{array}{l}\text { hiperplasia } \\
\text { Paratireóide }\end{array}$ & & GT & $\mathrm{MOH}$ & $\mathrm{CC}$ & NL & SEM MUTAÇÃO \\
\hline
\end{tabular}


Continuação da Tabela 13.

\begin{tabular}{|c|c|c|c|c|c|c|c|c|}
\hline Paciente & \multirow{2}{*}{$\begin{array}{c}\text { amostra } \\
96\end{array}$} & \multirow{2}{*}{$\begin{array}{c}\text { Tumor } \\
\begin{array}{c}\text { carcinóide brônquico com } \\
\text { metástase }\end{array}\end{array}$} & \multirow[t]{2}{*}{$\begin{array}{c}\text { p27 } \\
\text { germinativo } \\
\text { V109G }\end{array}$} & \multicolumn{3}{|c|}{ p27 somático Ex.1 } & \multirow{2}{*}{$\begin{array}{c}\begin{array}{c}\text { p27 } \\
\text { somático } \\
\text { Ex.2 }\end{array} \\
\mathrm{NL}\end{array}$} & \multirow{2}{*}{$\begin{array}{c}\text { Mutação somática p27 } \\
\text { SEM MUTAÇÃO }\end{array}$} \\
\hline \multirow{11}{*}{$\begin{array}{l}\text { Continuação } \\
\text { Individuo11 }\end{array}$} & & & & GT & $\mathrm{MOH}$ & - & & \\
\hline & 97 & $\begin{array}{c}\text { carcinóide brônquico com } \\
\text { metástase }\end{array}$ & & GT & $\mathrm{MOH}$ & $\mathrm{CC}$ & NL & SEM MUTAÇÃO \\
\hline & 98 & $\begin{array}{c}\text { carcinóide brônquico com } \\
\text { metástase }\end{array}$ & & GT & $\mathrm{MOH}$ & - & NL & SEM MUTAÇÃO \\
\hline & 99 & $\begin{array}{c}\text { carcinóide brônquico com } \\
\text { metástase }\end{array}$ & & GT & $\mathrm{MOH}$ & $\mathrm{CC}$ & NL & SEM MUTAÇÃO \\
\hline & 100 & $\begin{array}{c}\text { carcinóide brônquico com } \\
\text { metástase }\end{array}$ & & GT & $\mathrm{MOH}$ & $\mathrm{CC}$ & NL & SEM MUTAÇÃO \\
\hline & 102 & $\begin{array}{c}\text { carcinóide brônquico com } \\
\text { metástase }\end{array}$ & & GT & $\mathrm{MOH}$ & $\mathrm{CC}$ & NL & SEM MUTAÇÃO \\
\hline & 103 & $\begin{array}{c}\text { carcinóide brônquico com } \\
\text { metástase }\end{array}$ & & GT & $\mathrm{MOH}$ & $\mathrm{CC}$ & NL & SEM MUTAÇÃO \\
\hline & 104 & $\begin{array}{c}\text { carcinóide brônquico com } \\
\text { metástase }\end{array}$ & & GT & $\mathrm{MOH}$ & $\mathrm{CC}$ & NL & SEM MUTAÇÃO \\
\hline & 105 & $\begin{array}{c}\text { carcinóide brônquico com } \\
\text { metástase }\end{array}$ & & GT & $\mathrm{MOH}$ & $\mathrm{CC}$ & NL & SEM MUTAÇÃO \\
\hline & 106 & Hiperplasia Adrenal & & GT & $\mathrm{MOH}$ & CT & $\mathrm{NL}$ & SEM MUTAÇÃO \\
\hline & 107 & Hiperplasia Adrenal & & GT & $\mathrm{MOH}$ & $\mathrm{CC}$ & - & $\mathrm{NI}$ \\
\hline \multirow{2}{*}{ Individuo 12} & 153 & $\begin{array}{l}\text { Hiperplasia de } \\
\text { paratireóide }\end{array}$ & \multirow{2}{*}{ GT } & GT & $\mathrm{MOH}$ & CT & NL & SEM MUTAÇÃO \\
\hline & 154 & $\begin{array}{l}\text { Hiperplasia de } \\
\text { paratireóide }\end{array}$ & & GT & $\mathrm{MOH}$ & CT & NL & SEM MUTAÇÃO \\
\hline
\end{tabular}


Continuação da Tabela 13.

\begin{tabular}{|c|c|c|c|c|c|c|c|c|}
\hline Paciente & amostra & Tumor & $\begin{array}{c}\text { p27 } \\
\text { germinativo } \\
\text { V109G }\end{array}$ & \multicolumn{3}{|c|}{ p27 somático Ex.1 } & $\begin{array}{c}\text { p27 } \\
\text { somático } \\
\text { Ex.2 }\end{array}$ & Mutação somática p27 \\
\hline \multirow{4}{*}{ Individuo 13} & 206 & $\begin{array}{l}\text { TNE pancreático não } \\
\text { funcionante; sem } \\
\text { metástase; KI67 1\% }\end{array}$ & \multirow{4}{*}{ TT } & $\mathrm{TT}$ & $\mathrm{NI}$ & $\mathrm{CC}$ & NL & SEM MUTAÇÃO \\
\hline & 204 & $\begin{array}{l}\text { TNE pancreático não } \\
\text { funcionante; sem } \\
\text { metástase; KI67 1\% }\end{array}$ & & TT & $\mathrm{NI}$ & $\mathrm{CC}$ & NL & SEM MUTAÇÃO \\
\hline & & $\begin{array}{l}\text { HIPERPLASIA NODULAR E } \\
\text { DIFUSA DE CÉLULAS }\end{array}$ & & & & & & \\
\hline & 189 & $\begin{array}{l}\text { PRINCIPAIS E OXIFÍLICAS } \\
\text { SEM ATIPIAS EM } \\
\text { PARATIREOIDE }\end{array}$ & & TT & $\mathrm{NI}$ & - & NL & SEM MUTAÇÃO \\
\hline Individuo14 & 194 & $\begin{array}{l}\text { HIPERPLASIA DE CÉLULAS } \\
\text { PRINCIPAIS E OXÍNTICAS } \\
\text { Paratireóide }\end{array}$ & GG & TT & $\mathrm{NI}$ & CT & NL & SEM MUTAÇÃO \\
\hline Individuo 15 & $\begin{array}{l}176 \\
188\end{array}$ & $\begin{array}{l}\text { Pâncreas } \\
\text { Pâncreas } \\
\end{array}$ & GT & $\begin{array}{l}\text { GT } \\
/ T\end{array}$ & $\begin{array}{l}\mathrm{MOH} \\
\mathrm{LOH}\end{array}$ & $\begin{array}{l}\mathrm{CC} \\
\mathrm{CC}\end{array}$ & $\begin{array}{l}- \\
\mathrm{NL}\end{array}$ & $\begin{array}{c}\text { SEM MUTAÇÃO } \\
\text { LOH / T }\end{array}$ \\
\hline \multirow{3}{*}{ Individuo 16} & 177 & Duodeno & \multirow{3}{*}{$? ? ?$} & GT & $\mathrm{MOH}$ & $\mathrm{CC}$ & $\mathrm{NL}$ & SEM MUTAÇÃO \\
\hline & 178 & $\begin{array}{c}\text { CARCINOMA } \\
\text { NEUROENDÓCRINO BEM } \\
\text { DIFERENCIADO } \\
\text { METASTÁTICO KI67 } \\
\text { POSITIVO (BAIXO ÍNDICE } \\
<2 \% \text { ) - Pâncreas }\end{array}$ & & GT & $\mathrm{MOH}$ & $\mathrm{CC}$ & NL & SEM MUTAÇÃO \\
\hline & 181 & $\begin{array}{c}\text { Gastrinoma } \\
\text { Duodeno }\end{array}$ & & GT & $\mathrm{MOH}$ & $\mathrm{CC}$ & NL & SEM MUTAÇÃO \\
\hline
\end{tabular}

Continua.. 
Continuação da Tabela 13.

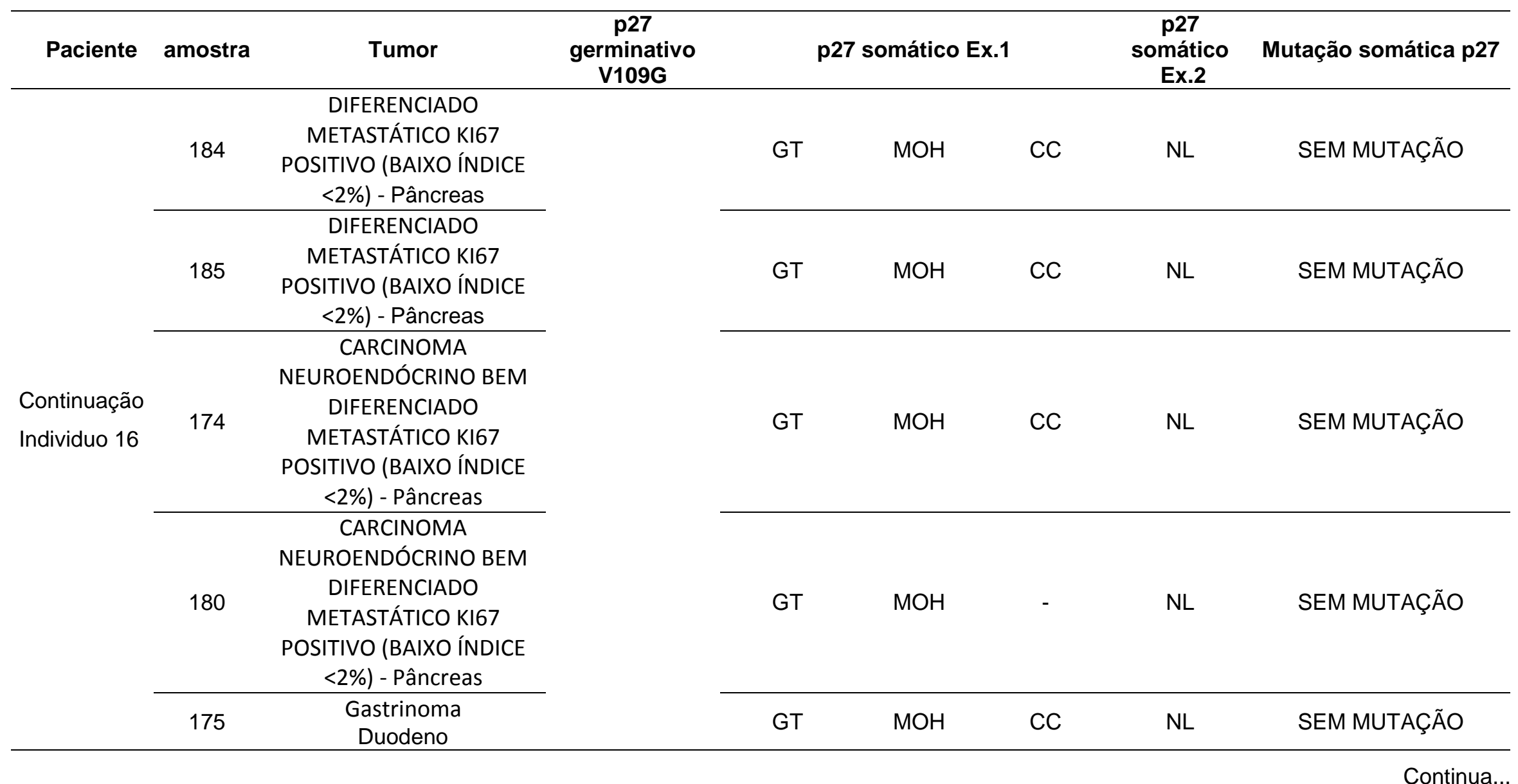


Continuação da Tabela 13.

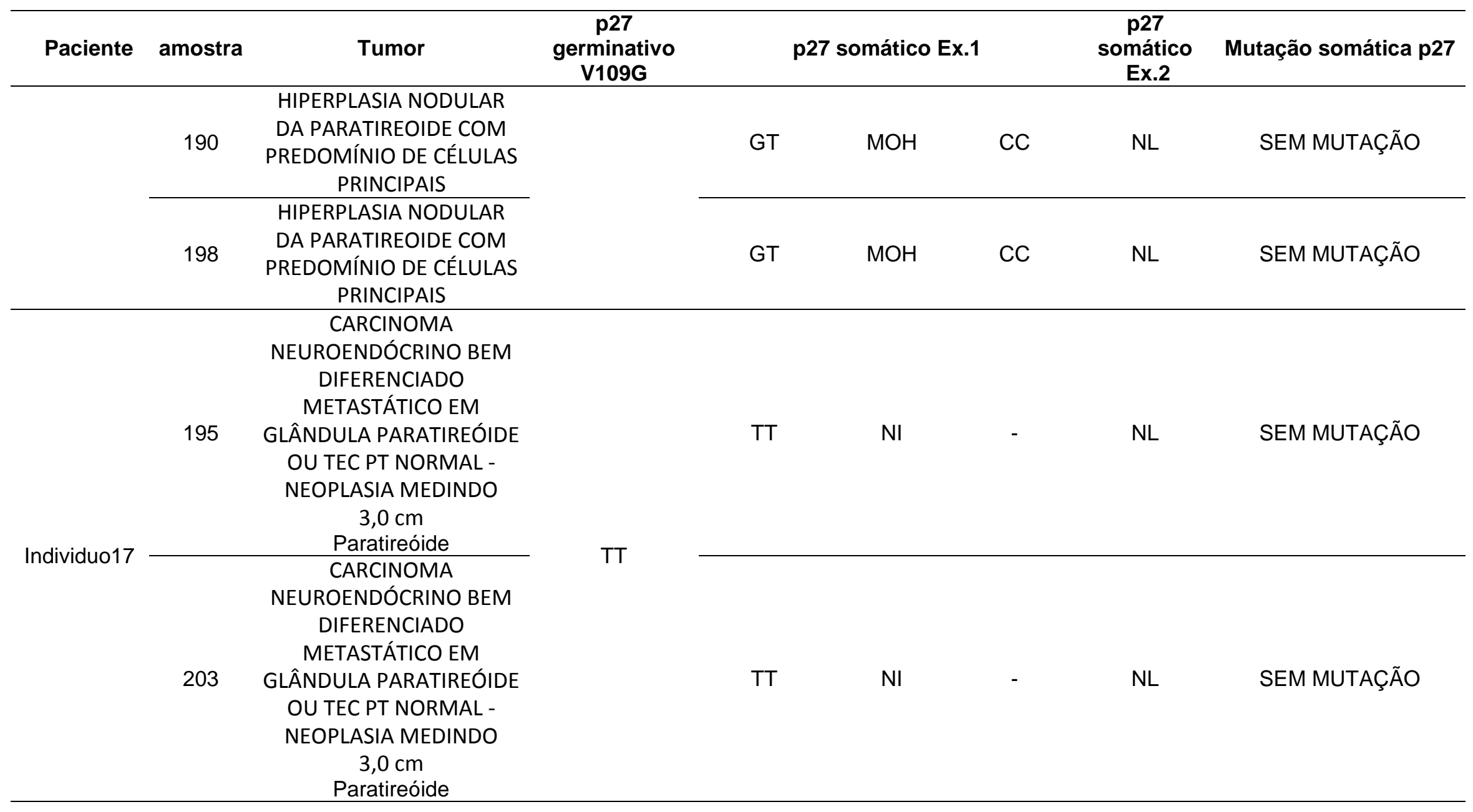


Continuação da Tabela 13.

\begin{tabular}{|c|c|c|c|c|c|c|c|c|}
\hline Paciente & amostra & Tumor & $\begin{array}{c}\text { p27 } \\
\text { germinativo } \\
\text { V109G }\end{array}$ & \multicolumn{3}{|c|}{ p27 somático Ex.1 } & $\begin{array}{c}\text { p27 } \\
\text { somático } \\
\text { Ex.2 }\end{array}$ & Mutação somática p27 \\
\hline \multirow{2}{*}{ Individuo18 } & 29 & Paratireóide & \multirow{2}{*}{ TT } & - & - & - & - & $\mathrm{NI}$ \\
\hline & 32 & Paratireóide & & - & - & - & - & $\mathrm{NI}$ \\
\hline \multirow{5}{*}{ Individuo 19} & 53 & Paratireóide & \multirow{5}{*}{ GT } & - & - & - & - & $\mathrm{NI}$ \\
\hline & 54 & Paratireóide & & - & - & - & - & $\mathrm{NI}$ \\
\hline & 57 & Paratireóide & & - & - & - & - & $\mathrm{NI}$ \\
\hline & 56 & Paratireóide & & GT & $\mathrm{MOH}$ & - & NL & SEM MUTAÇÃO \\
\hline & 55 & Paratireóide & & GT & $\mathrm{MOH}$ & GT & NL & SEM MUTAÇÃO \\
\hline \multirow{5}{*}{ Individuo 20} & 64 & Pâncreas & \multirow{5}{*}{ GT } & GT & $\mathrm{MOH}$ & - & NL & SEM MUTAÇÃO \\
\hline & 65 & Pâncreas & & - & - & - & - & $\mathrm{NI}$ \\
\hline & 66 & Pâncreas & & - & - & - & - & $\mathrm{NI}$ \\
\hline & 68 & Pâncreas normal & & GT & $\mathrm{MOH}$ & - & NL & SEM MUTAÇÃO \\
\hline & 69 & Pâncreas & & - & - & - & - & $\mathrm{NI}$ \\
\hline \multirow{4}{*}{ Individuo 21} & 75 & $\begin{array}{c}\text { adenoma (fenocópia) } \\
\text { Paratireóide }\end{array}$ & \multirow{4}{*}{ ??? } & $-1 \mathrm{~T}$ & $\mathrm{LOH}$ & - & NL & $\mathrm{LOH} / \mathrm{T}$ \\
\hline & 76 & tec normal & & - & - & - & - & $\mathrm{NI}$ \\
\hline & 77 & Paratireóide & & - & - & - & - & $\mathrm{NI}$ \\
\hline & 6 & ADRENAL & & GT & $\mathrm{MOH}$ & - & NL & SEM MUTAÇÃO \\
\hline
\end{tabular}


Continuação da Tabela 13.

\begin{tabular}{|c|c|c|c|c|c|c|c|c|}
\hline Paciente & amostra & Tumor & $\begin{array}{c}\text { p27 } \\
\text { germinativo }\end{array}$ & \multicolumn{3}{|c|}{ p27 somático Ex.1 } & \multirow{2}{*}{$\begin{array}{c}\text { p27 } \\
\text { somático } \\
\text { Ex.2 } \\
- \\
\end{array}$} & \multirow{2}{*}{$\begin{array}{c}\text { Mutação somática p27 } \\
\mathrm{NI}\end{array}$} \\
\hline \multirow{6}{*}{ Individuo 22} & 79 & lesão orelha & \multirow{6}{*}{ GG } & - & - & - & & \\
\hline & 80 & $\begin{array}{c}\text { carcinoma epidermóide } \\
\text { bem diferenciado, invasivo } \\
\text { lesão lábio }\end{array}$ & & - & - & - & - & $\mathrm{NI}$ \\
\hline & 81 & $\begin{array}{l}\text { carcinoma epidermóide } \\
\text { bem diferenciado, invasivo } \\
\text { lesão lábio }\end{array}$ & & - & - & - & - & $\mathrm{NI}$ \\
\hline & 90 & $\begin{array}{l}\text { carcinoma epidermóide } \\
\text { bem diferenciado, invasivo } \\
\text { lesão lábio }\end{array}$ & & - & - & - & - & $\mathrm{NI}$ \\
\hline & 82 & $\begin{array}{l}\text { carcinoma epidermóide } \\
\text { bem diferenciado, invasivo } \\
\text { lesão lobo NFDR E }\end{array}$ & & - & - & - & - & $\mathrm{NI}$ \\
\hline & 171 & $\begin{array}{l}\text { carcinoma epidermóide } \\
\text { bem diferenciado, invasivo } \\
\text { lesão Li orelha }\end{array}$ & & GG & $\mathrm{NI}$ & $\mathrm{CC}$ & NL & SEM MUTAÇÃO \\
\hline \multirow{5}{*}{ Individuo 23} & 83 & $\begin{array}{l}\text { Angiofibroma } \\
\text { Lesão nariz }\end{array}$ & \multirow{5}{*}{ TT } & - & - & - & - & $\mathrm{NI}$ \\
\hline & 84 & $\begin{array}{l}\text { Angiofibroma } \\
\text { Lesão nariz }\end{array}$ & & - & - & - & - & $\mathrm{NI}$ \\
\hline & 85 & $\begin{array}{l}\text { Angiofibroma } \\
\text { Lesão nariz }\end{array}$ & & - & - & - & - & $\mathrm{NI}$ \\
\hline & 86 & $\begin{array}{l}\text { Angiofibroma } \\
\text { Lesão nariz }\end{array}$ & & - & - & - & - & $\mathrm{NI}$ \\
\hline & 87 & $\begin{array}{l}\text { Angiofibroma } \\
\text { Lesão nariz }\end{array}$ & & - & - & - & - & $\mathrm{NI}$ \\
\hline
\end{tabular}

Continua. 
Continuação da Tabela 13.

\begin{tabular}{|c|c|c|c|c|c|c|c|c|}
\hline Paciente & amostra & Tumor & $\begin{array}{c}\text { p27 } \\
\text { germinativo } \\
\text { V109G }\end{array}$ & \multicolumn{3}{|c|}{ p27 somático Ex.1 } & $\begin{array}{c}\text { p27 } \\
\text { somático } \\
\text { Ex.2 }\end{array}$ & Mutação somática p27 \\
\hline \multirow{3}{*}{$\begin{array}{l}\text { Continuação } \\
\text { Individuo } 23\end{array}$} & 88 & $\begin{array}{l}\text { Colagenoma } \\
\text { Lesão tórax }\end{array}$ & & - & - & - & - & $\mathrm{NI}$ \\
\hline & 120 & $\begin{array}{l}\text { HIPERPLASIA DE } \\
\text { PARATIRÓIDE }\end{array}$ & & - & - & - & - & $\mathrm{NI}$ \\
\hline & 135 & $\begin{array}{l}\text { HIPERPLASIA DE } \\
\text { PARATIRÓIDE }\end{array}$ & & - & - & - & - & $\mathrm{NI}$ \\
\hline \multirow{2}{*}{ Individuo 24} & 93 & Paratireóide & \multirow{2}{*}{ GT } & GT & $\mathrm{MOH}$ & - & - & $\mathrm{NI}$ \\
\hline & 101 & Carcinoide & & GT & $\mathrm{MOH}$ & - & $\mathrm{NL}$ & SEM MUTAÇÃO \\
\hline \multirow{3}{*}{ Individuo 25} & 110 & lesão do tronco & \multirow{3}{*}{ GT } & - & - & - & - & $\mathrm{NI}$ \\
\hline & 111 & lesão do tronco & & GT & $\mathrm{MOH}$ & CT & $\mathrm{NL}$ & SEM MUTAÇÃO \\
\hline & 112 & lesão do tronco & & GT & $\mathrm{MOH}$ & CT & $\mathrm{NL}$ & SEM MUTACCÃO \\
\hline \multirow{2}{*}{ Individuo 26} & 124 & Paratireóide & \multirow{2}{*}{ GT } & GT & $\mathrm{MOH}$ & CT & $\mathrm{NL}$ & SEM MUTAÇÃO \\
\hline & 136 & $14 / 01 / 2005$ & & - & - & - & - & $\mathrm{NI}$ \\
\hline \multirow{2}{*}{ Individuo 27} & 127 & Paratireóide & \multirow{2}{*}{ GT } & - & - & - & - & $\mathrm{NI}$ \\
\hline & 129 & Paratireóide & & - & - & - & - & $\mathrm{NI}$ \\
\hline Individuo 28 & 144 & $\begin{array}{l}\text { HIPERPLASIA NODULAR E } \\
\text { DIFUSA DE CELUULAS } \\
\text { PRINCIPAIS } \\
\text { (PREDOMINANTE) E } \\
\text { OXIFÍLICAS }\end{array}$ & TT & TT & $\mathrm{NI}$ & - & NL & SEM MUTAÇÃO \\
\hline \multirow{2}{*}{ Individuo 29} & 156 & Criopreservado 16/06/09 & \multirow{2}{*}{ TT } & TT & $\mathrm{NI}$ & - & $\mathrm{NL}$ & SEM MUTAÇÃO \\
\hline & 157 & Criopreservado 16/06/09 & & TT & $\mathrm{NI}$ & - & $\mathrm{NL}$ & SEM MUTAÇÃO \\
\hline \multirow{3}{*}{ Individuo 30} & 160 & $\begin{array}{l}\text { adenoma hipofisário não- } \\
\text { funcionante }\end{array}$ & \multirow{3}{*}{ ??? } & - & - & - & - & $\mathrm{NI}$ \\
\hline & 161 & $\begin{array}{l}\text { adenoma hipofisário não- } \\
\text { funcionante }\end{array}$ & & - & - & - & - & $\mathrm{NI}$ \\
\hline & 212 & $\begin{array}{l}\text { adenoma hipofisário não- } \\
\text { funcionante }\end{array}$ & & - & - & - & NL & $\mathrm{NI}$ \\
\hline
\end{tabular}


Conclusão da Tabela 13.

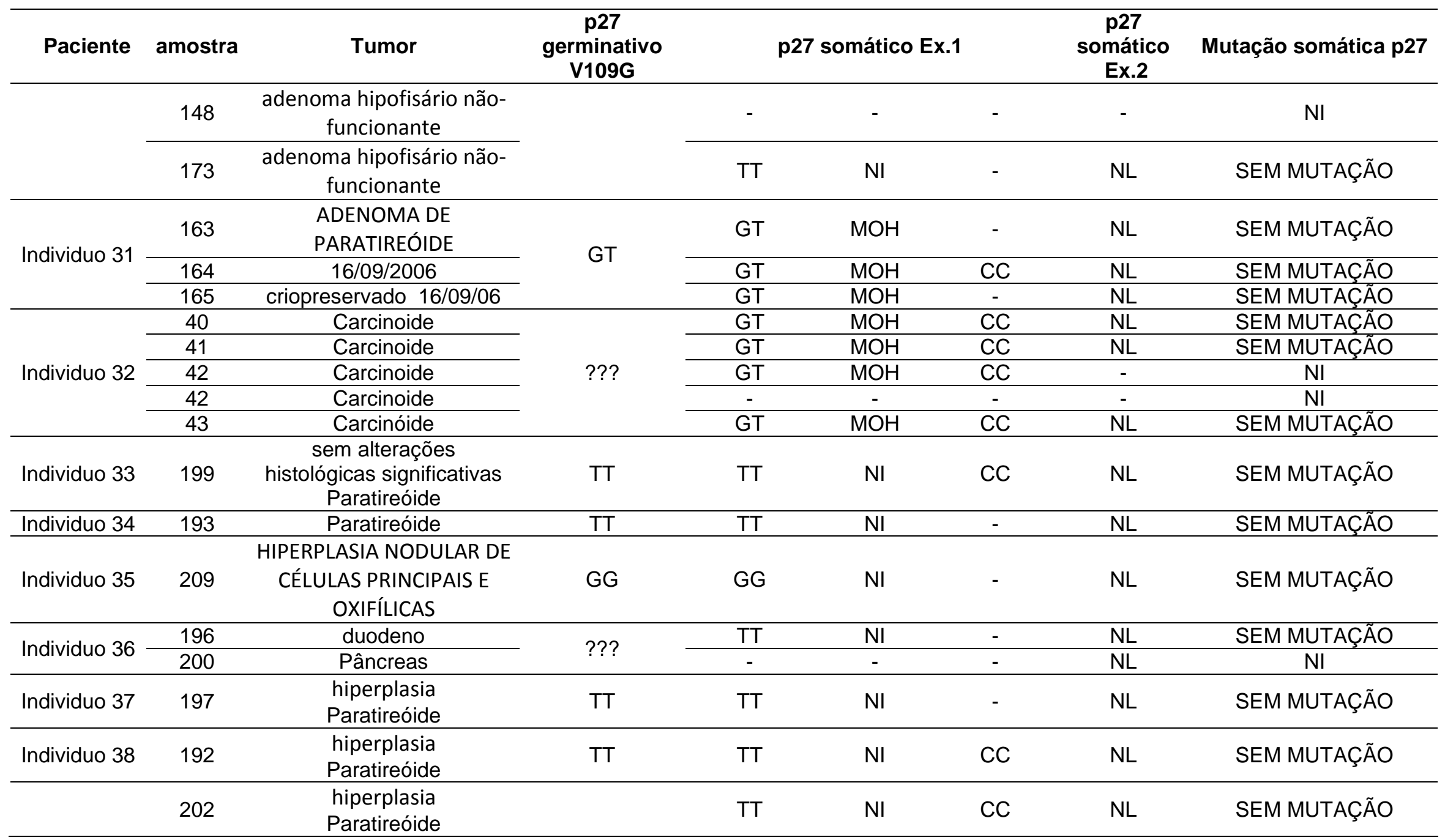




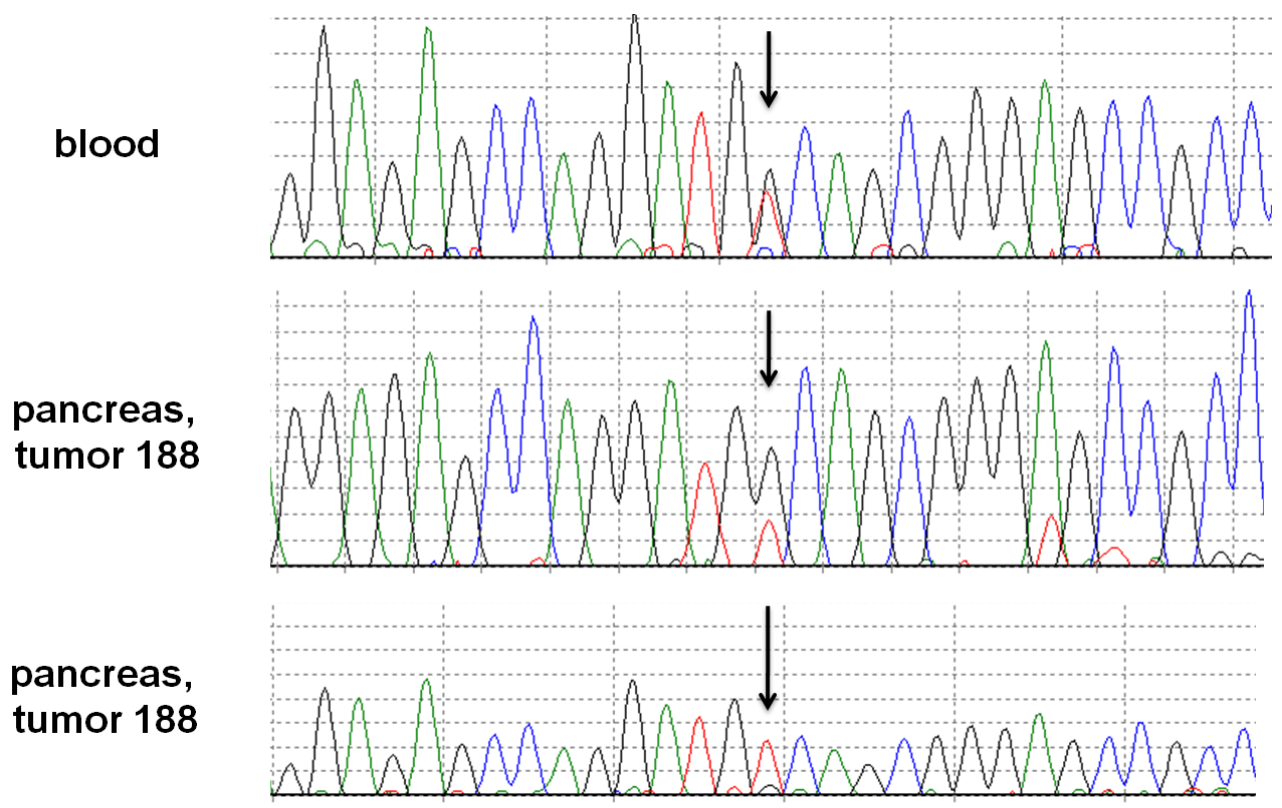

Figura 21: $O$ primeiro eletroferograma do sequenciamento do éxon 1 do gene p27Kip1 em sangue de paciente com mutação germinativa MEN1 mostra a presença dos dois alelos (G e T) do polimorfismo V109G na amostra de DNA do sangue, enquanto nos sequenciamentos abaixo, dos tumor de pâncreas desse paciente, nota-se maior prevalência do alelo $\mathrm{T}$. Esse resultado indica a ocorrência de LOH-p27Kip1 nesse tumor, um gastrinoma metastático, diagnosticado aos 37 anos de idade

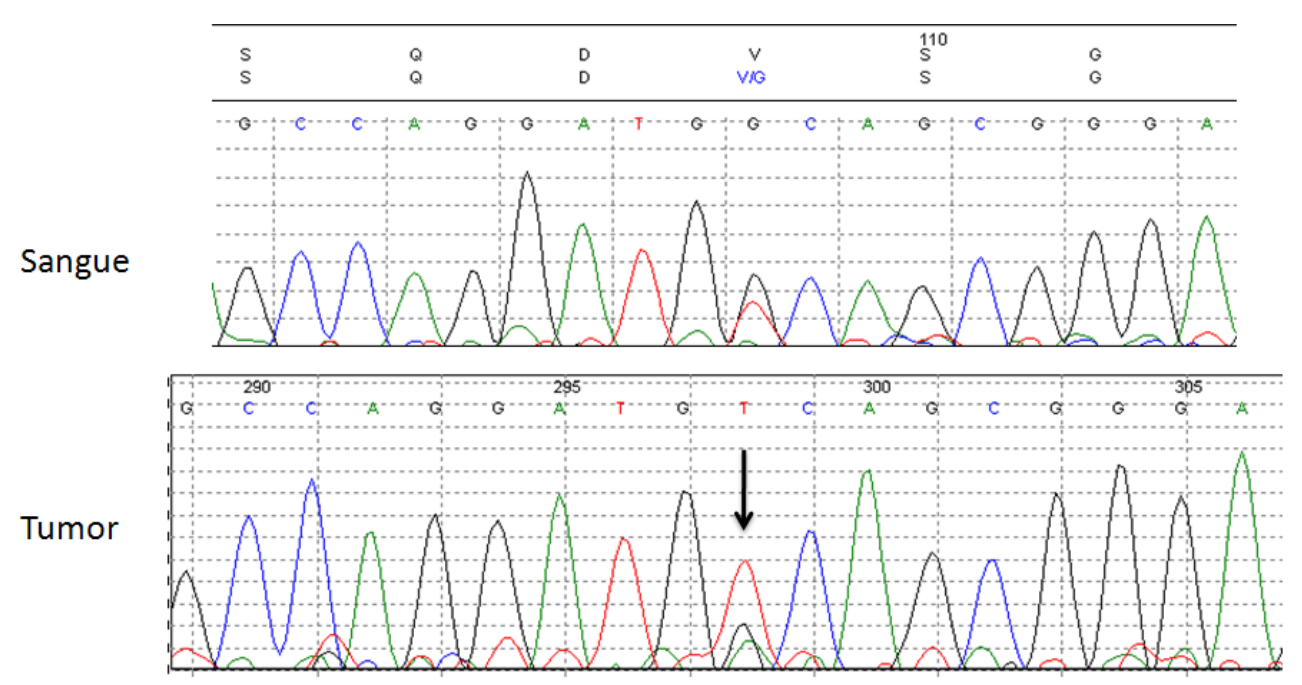

Figura 22: Nota-se maior prevalência do alelo selvagem, $G$, no seqüenciamento do DNA de sangue do paciente NEM1 com mutação no gene MEN1 e maior prevalência do alelo T no DNA do tumor de paratireóide. Esse resultado indica LOH-p27Kip1 


\subsection{Análise de LOH no gene AIP em tumores NEM1}

Foram analisados 35 tecidos neoplásicos para analise de $\mathrm{LOH}$ do gene AIP

5.4.1 Análise de perda de heterozigose com 0 marcador de microssatélite D11S1258

Através da análise do marcador D11S1258, foi observada perda de heterozigose em células de adenomas de paratireóides.(Figuras 23 e 24)

\section{D11S1258, Sangue}

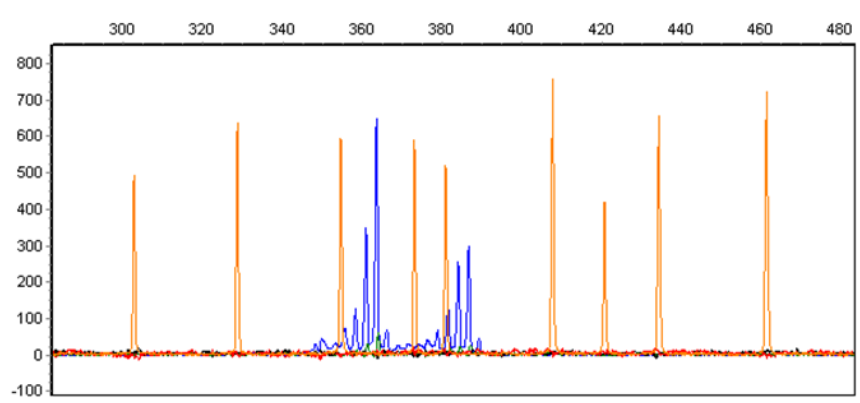

D11S1258, Adenoma de paratireóide

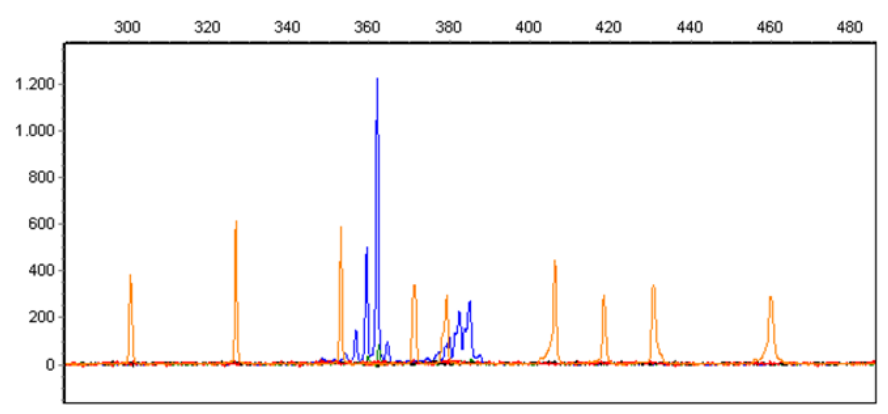

Figuras 23 e 24: Acima, podemos identificar a presença de dois alelos nas células do sangue. Abaixo, observamos a ausência da amplificação de um dos alelos, indicando perda de heterozigose nas células tumorais do adenoma de paratireóide. 

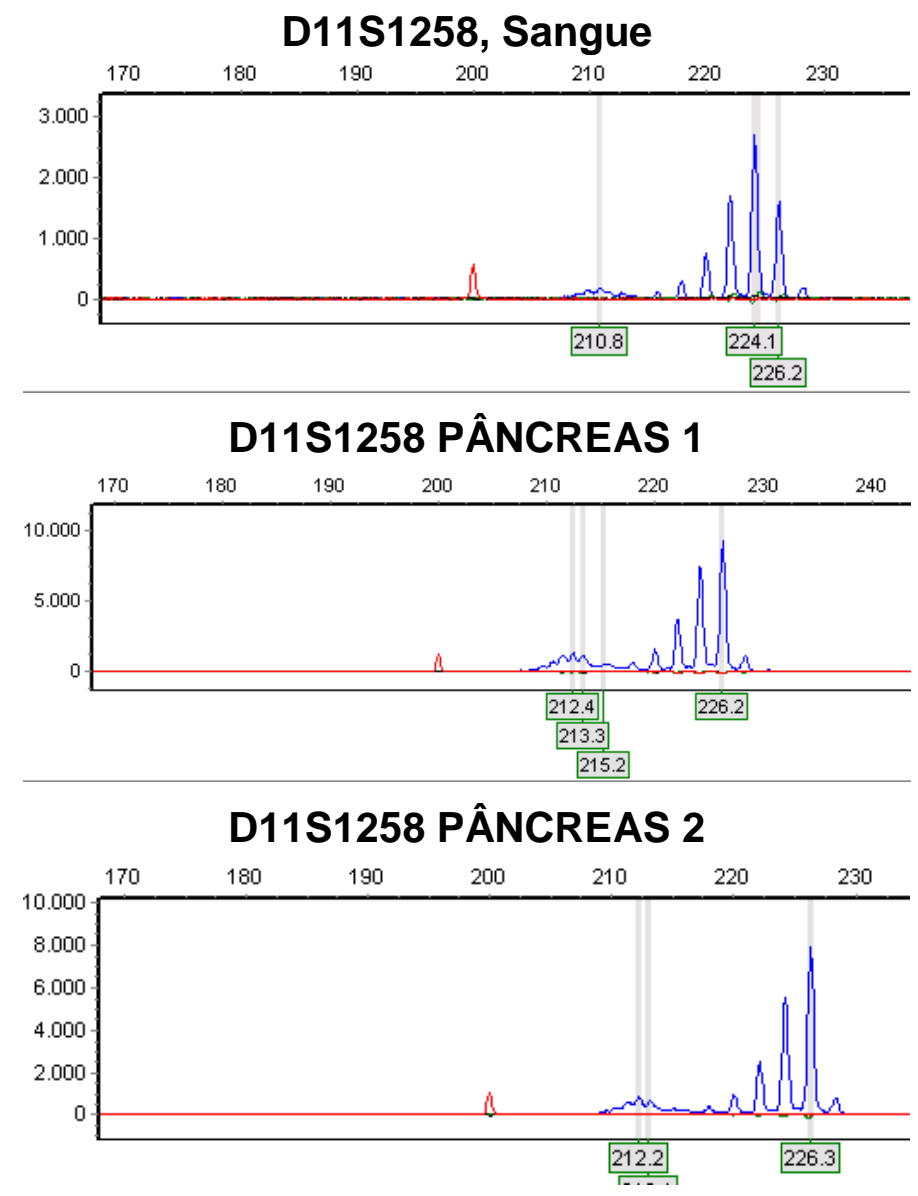

\section{D11S1258 PÂNCREAS 3}

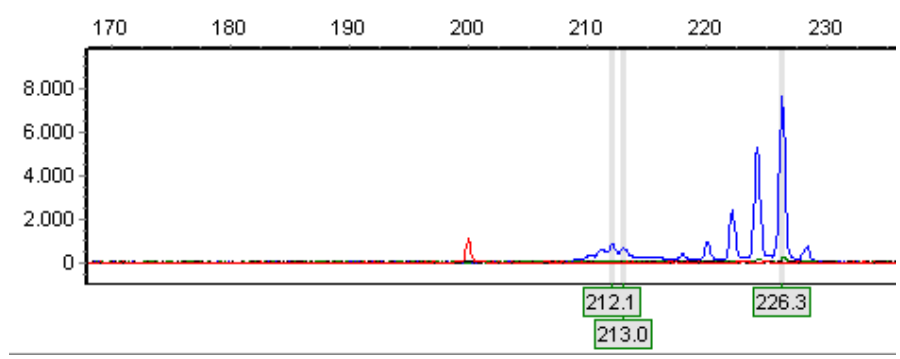

\section{D11S1258 PARATIREÓIDE}

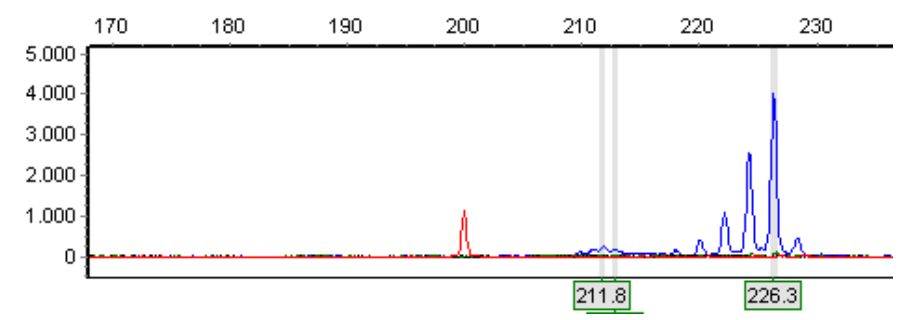

Figura 25: Análise de LOH por marcador $\overline{\mathrm{D} 11 \mathrm{~S}}$, 1258, onde os e três tumores de pâncreas e uma neoplasia de paratireoide apresentaram evidencias claras de LOH 
Tabela 14: Resultados de análises de DNA leucocitário e tecidos de pacientes com NEM1 através do marcador de microssatélite D11S1258.Em negrito estão as análises informativas que mostraram manutenção ou perda de heterozigose do tumor

\section{Marcador de Microssatélite D11S1258}

\begin{tabular}{|c|c|c|c|c|c|c|c|}
\hline Pacientes & Sangue & glândula 1 & Tumor & glândula 2 & tumor & glândula 3 tumor & Resultado \\
\hline Individuo 4 & AA & $\begin{array}{l}\text { Gastrinoma } \\
\text { (Duodeno) }\end{array}$ & $\mathrm{NI}$ & & & & \\
\hline Individuo 6 & $\mathrm{AA}$ & $\begin{array}{c}\text { Colagenoma } \\
\text { (Tórax posterior } \\
\text { superior) }\end{array}$ & $\mathrm{NI}$ & & & & $\mathrm{NI}$ \\
\hline Individuo 7 & AA & $\begin{array}{c}\text { Carcinoma } \\
\text { epidermóide bem } \\
\text { diferenciado } \\
\text { Invasivo } \\
\text { (Tecido orelha) }\end{array}$ & $\mathrm{MH}$ & $\begin{array}{c}\text { Carcinoma } \\
\text { epidermoide bem } \\
\text { diferenciado } \\
\text { invasivo } \\
\text { (Lábio) }\end{array}$ & $\mathrm{MH}$ & & $\mathrm{MH}$ \\
\hline Individuo 8 & $\mathrm{AA}$ & $\begin{array}{c}\text { Paratireóide } \\
\text { (Anterior Superior) }\end{array}$ & $\mathrm{NI}$ & & & & \\
\hline Individuo 9 & AA & Paratireóide (PTIE) & $\mathrm{LOH}$ & $\begin{array}{l}\text { Paratireóide } \\
\text { (PTSD }\end{array}$ & $\mathrm{LOH}$ & & \\
\hline Individuo 10 & AA & $\begin{array}{l}\text { Angiofibroma } \\
\text { inflamado } \\
\text { (Nariz) })\end{array}$ & $\mathrm{MH}$ & $\begin{array}{c}\text { Colagenoma } \\
\text { (Pele tórax } \\
\text { posterior } \\
\text { Esquerdo) }\end{array}$ & $\mathrm{MH}$ & & $\mathrm{MH}$ \\
\hline Individuo 12 & $\mathrm{AA}$ & Parat normal E & $\mathrm{MH}$ & Adenoma & $\mathrm{MH}$ & & $\mathrm{MH}$ \\
\hline
\end{tabular}




\subsubsection{Análise de LOH com o marcador de microssatélite D11S2072}

Através da análise do marcador D11S1258, foi observada manutenção de heterozigose em células de colagenomas. (Figuras 26 e 27)

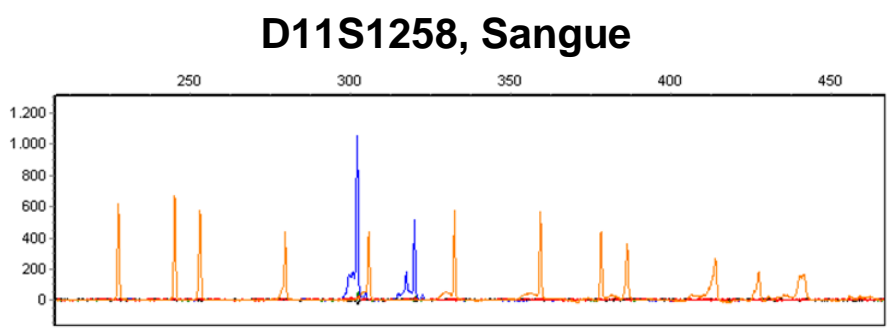

\section{D11S1258, Colagenoma}

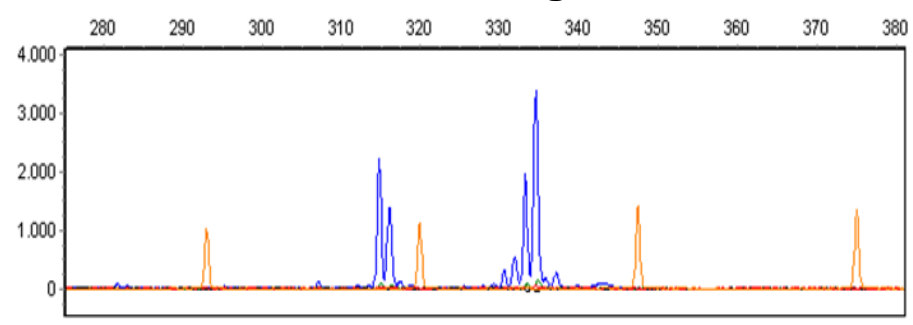

Figuras 26 e 27: Observamos a amplificação de dois alelos do marcador

D11S 1258 no sangue e nas células do tumor de pele colagenoma 
Tabela 15: Resultados de análises de DNA leucocitário e tecidos de pacientes com NEM1 através do marcador de microssatélite D11S2072. Em negrito as análises que mostraram manutenção de heterozigose

\section{Marcador de Microssatelite D11S 2072}

\begin{tabular}{|c|c|c|c|c|c|c|c|c|}
\hline Pacientes & Sangue & glândula 1 & Tumor & glândula 2 & tumor & glândula 3 & tumor & Resultado \\
\hline Individuo 4 & AA & $\begin{array}{l}\text { Gastrinoma } \\
\text { (Duodeno) }\end{array}$ & $\mathrm{NI}$ & & & & & \\
\hline Individuo 7 & AA & $\begin{array}{l}\text { Carcinoma } \\
\text { epidermoide bem } \\
\text { diferenciado } \\
\text { Invasivo } \\
\text { (Tecido orelha) }\end{array}$ & $\mathrm{NI}$ & $\begin{array}{l}\text { Carcinoma } \\
\text { epidermoide bem } \\
\text { diferenciado } \\
\text { invasivo } \\
\text { (Lábio) }\end{array}$ & $\mathrm{NI}$ & AA & $\mathrm{NI}$ & $\mathrm{NI}$ \\
\hline Individuo 8 & AA & $\begin{array}{c}\text { Paratireóide } \\
\text { (Anterior Superior) }\end{array}$ & MH & & & & & MH \\
\hline Individuo 9 & AA & Paratireóide (PTIE) & $\mathrm{NI}$ & $\begin{array}{l}\text { Paratireóide } \\
\text { (PTSD) }\end{array}$ & $\mathrm{NI}$ & & & $\mathrm{NI}$ \\
\hline Individuo 10 & AA & $\begin{array}{c}\text { Angiofibroma } \\
\text { inflamado } \\
\text { (Nariz) }\end{array}$ & MH & $\begin{array}{c}\text { Colagenoma } \\
\text { (Pele tórax } \\
\text { posterior } \\
\text { Esquerdo) }\end{array}$ & MH & & & MH \\
\hline Individuo 12 & AA & Parat normal E & $\mathrm{MH}$ & Adenoma & $\mathrm{MH}$ & & & \\
\hline
\end{tabular}


6 DISCUSSÃO 
Apresentamos nesse projeto de Mestrado resultados sobre o status do principal gene associado à NEM1, o gene supressor de tumor MEN1, e dos genes recentemente associado à NEM1 e ao fenótipo chamado NEM1-like, genes p27Kip1 e AIP. Nos valendo da extensa coleção de tumores de pacientes com NEM1 do grupo UEG-FMUSP, coletados nos últimos 10-15 anos, pudemos realizar investigação original, ainda não reportada na literatura.

\subsection{Status somático de MEN1}

Inicialmente, pudemos observar freqüente perda somática do alelo normal do gene MEN1 em tumores de pacientes com NEM1. O MEN1 é um gene supressor de tumor cuja tumorigênese está associada à inativação de um dos alelos por mutação germinativa e à inativação do segundo alelo por 11q13-LOH (Chandrasekharappa SC, 1997). A combinação desses dois eventos genéticos leva à inativação da proteína MENIN nas células das glândulas NEM1-relacionadas, que passam a ter vantagens proliferativas e consequentemente a desenvolver tumores (Balogh, 2006). Setenta e seis tumores analisados no presente projeto, provenientes de diversos tecidos, apresentavam 11q13-LOH (Tabela 7). O processo tumorigênico de inativação bi-alélica foi descrito em quase todos os tumores NEM1relacionados, com exceção ao tumor adrenocortical (Brandi, 2001, Costa $\mathrm{MH}, 2011)$. Discute-se que a haploinsuficiencia já seria capaz de promover tumorigênese no córtex da adrenal. Nossos dados corroboram esses achados, uma vez que dos quatro tumores adrenocorticais que analisamos, nenhum deles apresentava LOH. Também não foi encontrada 11q13-LOH em quarenta neoplasias envolvendo praticamente todos os principais 
tumores NEM1 (HPT, pâncreas, adrenal, carcinóide). A manutenção de heterozigose observada nessas amostras pode ter três explicações principais: a) contaminação com tecido normal periférico (vasos, estroma) ou b) o estudo de paratireóides normais removidas cirurgicamente para evitar recidiva do hiperparatireoidismo, e c) a ocorrência de tumorigenese de tumores de pacientes com NEM1 com mecanismo molecular não envolvendo a perda do alelo normal $(\mathrm{LOH})$.

\subsection{Status somático de p27Kip1}

Quanto às análises do p27Kip1, não foi encontrada nenhuma variante somática potencialmente inativadora (mutação) nos cento e dez tumores sequenciados. Estudos anteriores reportaram que mutações germinativas em p27Kip1 são bastante raras (Agarwal 2009, Igreja 2009). Nossos dados indicam, pela primeira vez, que mutações somáticas no gene p27Kip1 em tumores de pacientes com NEM1 também são pouco frequentes.

Interessante notar que entre os tumores cujo genótipo dos polimorfismos apresentavam-se em heterozigose, e assim eram informativos para $\mathrm{LOH}$, foi observada perda somática do gene p27kip 1 em 5 tumores NEM1 (5/57, 8,7\%) (Figuras 11 e 12). Trata-se da primeira vez que é mostrada perda de p27Kip1 em tumores de pacientes com NEM1, sugerindo um novo mecanismo molecular no qual MEN1 e p27Kip1 encontram-se inativados ao mesmo tempo em tumores MEN1. Os dados de um artigo recentemente publicado no JCEM também sugerem perda sinérgica de MEN1 e p27Kip1, mas em tumores de pacientes com mutação germinativa no gene p27Kip1, e não no gene MEN1, como mostramos aqui (Costa-Guda, 2011). Nesse estudo, 86 pacientes com hiperparatireoidismo aparentemente esporádico foram rastreados genicamente, e quatro desses casos (4.65\%) apresentavam mutação germinativa no gene p27Kip1. Apesar de LOH no locus de p27Kip1 ter sido encontrada em somente 
um desses tumores, dois tumores apresentavam perda somática de MEN1, indicando que o segundo evento genético de tumores de pacientes com mutaçao germinativa nem sempre ocorre no mesmo gene, mas pode ocorrer em um outro gene da mesma via tumorigênica (Costa-Guda, 2011); da mesma forma como encontramos nos tumores NEM1.

\subsection{Manifestações clínicas associadas a perda somática de $p 27$}

A comparação detalhada das características dos tumores NEM1 com p27Kip1-LOH com os tumores sem p27Kip1-LOH estão em andamento. Entretanto, podemos observar fenótipos bastante simliares entre os dois grupos. Aparentemente, tanto os tumores de paratireóides quanto o tumor de pâncreas não são mais agressivos em comparação com os demais tumores sem p27Kip1-LOH.

Isso sugere que os demais tumores podem apresentar eventos epigenéticos de inativação de p27, como através da metilação gênica, por exemplo. De fato, foi mostrado que a inativação da proteína MENIN in vitro causa a diminuindo a transcrição do gene p27Kip1 (Karnik, 2005).

\subsection{Status somático de AIP}

A investigação do gene AIP em tumores de pacientes com NEM1 foi realizada por marcadores de microssatélites do cromossomo 11. Os resultados mostrando LOH no locus de AIP não estão necessariamente associadas a tumorigenese, ja que podem ter sido causadas em consequência da perda do alelo normal do gene MEN1 naquela mesma região cromossômica (11q13-11q13.3). Entretanto, como AIP é um gene 
supressor de tumor mostrado anteriormente estar envolvido e na tumorigenese endócrina, mais precisamente de tumores hipofisários, nossos achados sugerem que a perda somática deste gene pode ser mais um mecanismo da gênese e/ou progressão de tumores NEM1. Nesse sentido, ha três trabalhos publicados na literatura indicando a associação de $A / P$ não somente com tumores hipofisários, mas sim com outros tipos de tumores endócrinos, todos relacionados com a síndrome NEM1 (Georgtsi 2007; Toledo 2010; Belar 2011). 


\section{CONCLUSÃO}


Nossos dados indicam que além de perda somática no loucs 11q13, os tumores NEM1 podem sofrer perdas adicionais nos genes supressores de tumor p27kip1 e AIP.

Essas são as primeiras evidências na literatura de um processo de tumorigênese multi-step na NEM1, envolvendo três eventos genéticos:

1. mutação germinativa no gene MEN1;

2. $11 \mathrm{q} 13-\mathrm{LOH}$

3. perda somática de dos genes supressores de tumor p27kip1 / AIP 
8 REFERÊNCIAS 
Agarwal SK, Mateo CM, Marx SJ. Rare mutations in cyclin-dependent kinase inhibitor genes in MEN1 and related states.J Clin Endocrinol Metab 2009. Impresso online doi $1210-581$.

Agarwal S. K.; Guru, S. C.; Heppner, C.; Erdos, M. R.; Collins, R. M.; Menin interacts with the AP1 transcription factor jun $D$ and represses jun-Dactivated transcription. Cell. 1999; 96: 143-152.

Åkerström G, Stålberg P, Hellman P. Surgical management of pancreaticoduodenal tumors in multiple endocrine neoplasia syndrome type 1. Clinics. 2012;67(Sup01), in press.

Bale SJ, Bale AE, Stewart $\mathrm{K}$, et al. Linkage analysis of multiple endocrine neoplasia type 1 with INT2 and other markers on chromosome 11. Genomics.1989; 4:320-322.

Balogh K, Racz K, Patocs A, et al .Menin and its interacting proteins: elucidation of menin function. Trends Endocrinol Metab. 2006; 17 (9):357-64.

Belar O, De la Hoz C, Pérez-Nanclares G, Castaño L, Gaztambide S; Spanish MEN1 Group. Novel Mutations In Men1, CDKN1b And AIP Genes In Patients With Multiple Endocrine Neoplasia Type 1 Syndrome In Spain. Clin Endocrinol (Oxf). 2011 Oct 25. doi: 10.1111/j.1365-2265.2011.04269.x. [Epub ahead of print] PubMed PMID: 22026581.

Benson L, Ljunghall S, Akerstrom G, Oberg K. Hyperparathyroidism presenting as the first lesion in multiple endocrine neoplasia type 1. Am J Med. 1987; 82 (4):731-7.

Bilezikian JP, Potts JT JR, Fuleihan GEL-H, Kleerekoper M, Neer R, Peacock M. Summary statement from a workshop on asymptomatic primary hyperparathyroidism: a perspective for the 21st century. J Clin Endocrinol Metab. 2002;87:5353-5361. 
Bone HG, Diagnosis of multiglandular endocrine neoplasias. Clin Chem 1990, 36 (5) :711-8

Brandi M.L., Gagel R.F., Angeli A., Bilezikian J.P., Beck-Peccoz P., Bordi C., Conte-Devolx B., Falchetti A., Gheri R.G., Libroia A., Lips C.J., Lombardi G.,

Burgess JR, David R, Greenaway TM, Parameswaran V, Shepherd JJ. Osteoporosis in multiple endocrine neoplasia type 1: severity, clinical significance, relationship to primary hyperparathyroidism, and response to parathyroidectomy. Arch Surg. 1999; 134 (10):1119-23.

Carling, T., Udelsman, R. Parathyroid surgery in familial hyperparathyroid disorders. J. Intern. Med. 2005, 257: 27-37.

Cavaco BM. Domingues R. Bacelar MC. et al. Mutational analysis of Portuguese families with multiple endocrine neoplasia type 1 reveals large germline deletions. Clin Endocrinol. (Oxf) 2002; 56, 465 - 473.

Chandrasekharappa S.C., Guru S.C., Manickam P., Olufemi S.E., Collins F.S., Emmert-Buck M.R., Debelenko L.V., Zuang Z., Lubensky I.A., Liotta L.A., Crabtree J.S., Wang Y., Roe B.A., Weisemann J., Boguski M.S., Agarwal S.K., Kester M.B., Kim Y.S., Heppner C., Dong Q., Spiegel A.M., Burns A.L., Marx S.J. (1997) Positional cloning of the gene for Multiple Endocrine Neoplasia Type 1. Science, 276, 404-407.

Chang BL, Zheng SL, Isaacs SD, Wiley KE, Turner A, Li G, Walsh PC, Meyers DA, Isaacs WB, Xu J. A polymorphism in the CDKN1B gene is associated with increased risk of hereditary prostate cancer. Cancer Res. 2004 64:1997-9.

Corbetta S. , Pizzocaro A, Peracchi $M$ et al, multiple endocrine neoplasia type 1 in patients with recognized pituitary tumors of different types. Clin Endocrinol 1997,47: 507-12

Costa-Guda J, Marinoni I, Molatore S, Pellegata NS, Arnold A. Somatic mutation and germline sequence abnormalities in CDKN1B, encoding p27Kip1, in sporadic parathyroid adenomas. J Clin Endocrinol Metab. 2011 Apr;96(4):E701-6. 
Coursaeux A., Grosgeorge J., Gaudray P. et al. Definition of the minimal MEN 1 candidate area based on a $5-\mathrm{Mb}$ integrated map of proximal 11q13.The European Consortium on MEN 1.Genomics. 1996; 37:354-365

Crabtree JS, Scacheri PC, Ward JM, et al. A mouse model of multiple endocrine neoplasia, type 1, develops multiple endocrine tumors. Proc Natl Acad Sci USA. 2001; 98:1118-1123

Crabtree JS, Scacheri PC, Ward JM, Mcnally SR, Swain GP, Montagna C, Hager JH, Hanahan D, Edlund H, Magnuson MA, Garrett-Beal L, Burns AL, Ried T, Chandrasekharappa SC, Marx SJ, Spiegel AM, Collins FS. Of Mice and MEN 1: Insulinomas in conditional mouse knockout. Mol Cell Biol. 2003; 23:6075-85

Daly AF, Rixhon M, Adam C, Dempegioti A, Tichomirowa MA, Beckers A. High prevalence of pituitary adenomas: a cross-sectional study in the province of Liege, Belgium. J Clin Endocrinol Metab. 2006 Dec; 91(12):476975. Epub 2006 Sep 12.

Delcore R, Friesen SR.Gastrointestinal neuroendocrine tumors. J Am Coll Surg 1994, 178: 187-211

Delellis RA. Biology of disease: multiple endocrine neoplasias syndromes revisited. Lab Invevest 1995, 75(5):494-505

Fero MI, Rivkin M, Tasch M, et al : A Syndrome Of Hyperplasia With Features Of Gigantism, Tumorigenesis, And Female Sterility In P27(Kip1)Deficient Mice. Cell 85: 733-44, 1996

Fontaniere S, Casse H, Bertolino P, Zhang CX. Analysis of p27(Kip1) expression in insulinomas developed in pancreatic beta-cell specific Men1 mutant mice. Fam Cancer. 2006; 5(1):49-54.PMID: 16528608 [PubMed indexed for MEDLINE].

Gagel RF. Polyendocrine disorders: multiple endocrine neoplasia. In Wilson JD, Foster DW.9 ed. Willians textbook of endocrinology. Philadelphia: Saunders Company, 1998. P. 1537-42. 
Geerdink, EA., Van der Luijt, R.B.\& Lips, C.J. (2003) Dopatients with multiple endocrine neoplasia syndrome type 1 benefit from periodical screening? European of Endocrinology, 149, 577-582.

Georgitsi M, Raitila A, Karhu A, Tuppurainen K, Makinen MJ, Vierimaa O, Paschke R, Saeger W, VAN DER LUIJT RB, Sane T, Robledo M, De Menis E, Weil RJ, Wasik A, Zielinskl G, Lucewicz O, Lubinski J, Launonen V, Vahteristo $P$, Aaltonen LA. Molecular diagnosis of pituitary adenoma predisposition caused by aryl hydrocarbon receptor-interacting protein gene mutations. Proc Natl Acad Sci U S A. 2007 Mar 6;104(10):4101-5. Epub 2007 Feb 28.

Gibril F, Chen YJ, Schrump DS, Vortmeyer A, Zhuang Z, Lubensky IA, et al. Prospective study of thymic carcinoids in patients with multiple endocrine neoplasia type 1. J Clin Endocrinol Metab 2003; 88 (3):1066-81.

Grama D, Skogseid B, Wilander E et al.Pancreatic tumors in multiple endocrine neoplasia type 1: clinical presentation and surgical treatment. World J Surg 1992, 16: 611-9

Greenspan FA. , Gardner DG. Neoplásia Endócrina Múltipla. 2006. In Endocrinologia Básica e ClínicaRio de Janeiro: Mc Graw Hill Editora Cap. 22, p. 685-690

Hanahan D, Weinberg RA. The hallmarks of cancer. Cell 2000 Jan 7;100(1):57-70.

Huang SC, Zhuang Z, Weil RJ, et al. Nuclear/cytoplasmic localization of the multiple endocrine neoplasia type 1 gene product, menin. Lab Invest. 1999; 79:301-310

Igreja S, Chahal HS, Akker SA, Gueorguiev M, Popovic V, Damjanovic S, Burman P, Wass JA, Quinton R, Grossman AB, Korbonits M. Assessment of p27 (cyclin-dependent kinase inhibitor 1B) and aryl hydrocarbon receptorinteracting protein (AIP) genes in multiple endocrine neoplasia (MEN1) syndrome patients without any detectable MEN1 gene mutations. Clin Endocrinol (Oxf). 2009 Feb;70(2):259-64. Epub 2008 Aug 15. 
Ikeo Y, Sakurai A, Suzuki R, Zhang MX, Koizumi S, Takeuchi Y, Yumita W, Nakayama J, Hashizume K. Proliferation-associated expression of the MEN1 gene as revealed by in situ hybridization: possible role of the menin as a negative regulator of cell proliferation under DNA damage. Lab Invest. 2000 Jun;80(6):797-804.

Janson M, Larsson C, Werelius B, et al. Detailed physical map of human chromosomal region 11q12-13 shows high meiotic recombination rate around the MEN 1 locus. Proc Natl Acad Sci USA. 1991; 88:10609-10613

Karnik SK, Hughes CM, Gu X, Rozenblatt-Rosen O, McLean GW, Xiong Y, Meyerson M, Kim SK. Menin regulates pancreatic islet growth by promoting histone methylation and expression of genes encoding p27Kip1 and p1|8INK4c. Proc Natl Acad Sci U S A. 2005 Oct; 11;102(41):14659-64. Epub 2005 Sep; 29. PMID: 16195383 [PubMed - indexed for MEDLINE]

Kawamata N, Morosetti R, Miller CW, Park D, Spirin KS, Nakamaki T, Takeuchi S, Hatta Y, Simpson J, Wilcyznski S, et al. Molecular analysis of the cyclin-dependent kinase inhibitor gene p27/Kip1 in human malignancies.Cancer Res. 1995 Jun 1;55(11):2266-9.

Kiyokawa H, Kineman RD, Manova-Todorova KO, Soares VC, Hoffman ES, Ono M, Khanam D, HaydayAC, Frohman LA, Koff A: Enhanced growth of mice lacking the cyclindependent kinase inhibitor function of p27(Kip1). Cell 85:721-32, 1996.

Knudson AG., 1971 Mutation and cancer: statistical study of retinoblastoma. Proc Natl Acad Sci USA 68:820-823.

Kouvaraki MA, Shapiro SE, Cote GJ, Lee JE, Yao JC, Waguespack SG, et al Management of pancreatic endocrine tumors in multiple endocrine neoplasia type 1. World J Surg. 2006; 30 (5):643-53

Larsson C., Skogseid, B., Oberg, K., et al. Multiple Endocrine Neoplasia Type 1 gene maps to chromosome 11 and is lost in insulinoma. Nature, 1988; 332, 85-87.

Lemmens, I.; Van De Ven, W. J. M.; Kas, K.; Zhang, C. X.; Giraud, S.; Wautot, V. et al. Identification of the Multiple Endocrine Neoplasia type 1 (MEN1) gene. The European Consortium on MEN 1 Hum Molec Genet. 1997; 6: 1177-1183. 
Lourenço DM Jr, Alves VA, Bronstein MD, Toledo SP. Isolated familial somatotropinoma: 11q13-loh and gene/protein expression analysis suggests a possible involvement of aip also in non-pituitary tumorigenesis. Clinics (Sao Paulo). 2010 Apr;65(4):407-15. PubMed PMID: 20454499; PubMed Central PMCID: PMC2862671.

Lourenco Jr DM, Coutinho FL, Toledo RA, Cavalcanti MG, Montenegro F, Machado MC, Toledo SPA. Variabilidade clínica na Neoplasia Endócrina Múltipla Tipo 1 (NEM-1): Estudo em 39 casos In: 27ํㅡ Congresso Brasileiro de Endocrinologia e Metabologia, 2006, Recife. Arqu Bras Endocrinol Metab. 2006; (50): S639.

Lourenco Jr DM, Coutinho FL, Toledo RA, Quedas E, Cavalcanti MG, Montenegro, F, et al. Hiperparatieoidismo Assintomático (HPTa) na Neoplasia Endócrina Múltipla Tipo 1 (NEM-1). Arqu Bras Endocrinol Metab. 2006; (50):S608.

Lourenço Jr, DM, Toledo SPA. Neuroendocrinologia Clínica e Cirúrgica. In: Liberman \& Cukier. Neuroendocrinologia Clínica e Cirúrgica. São Paulo : Lemos Editora, 2002. p.577.

Lourenço-Jr DM, Alves VA, Bronstein MD, Toledo SP.; Isolated familial somatotropinoma: 11q13-loh and gene/protein expression analysis suggests a possible involvement of aip also in non-pituitary tumorigenesis. Clinics (Sao Paulo). 2010 Apr; 65 (4):407-15.

Lourenço-JR, D.M., Toledo, R. A., Coutinho, F. L., Toledo, S. P. A. The impact of clinical and genetic screnning of Multiple Endocrine Neoplasia type 1 (MEN1) at the Hospital das Clínicas, São Paulo. Clinics, 2007; 62: 465-476

Lubensky I A, Debelenko LV, Zhuang Z, et al Allelic deletions on chromosome $11 \mathrm{q} 13$ in multiple tumors from individual MEN 1 patients. Cancer Res. 1996; 56:5272-5278

Mallette, L. E. Management of hyperparathyroidism in the multiple endocrine neoplasia syndromes and other familial endocrinopathies. Endocrinol. Metab. Clin. North Am., v. 23, n.1, p. 19-36, 1994

Mannelli M., Pacini F., Ponder B.A., Raue F., Skogseid B., Tamburrano G., Thakker R.V., Thompson N.W., Tomassetti P., Tonelli F., Wells S.A. Jr., Marx S.J. Guidelines for diagnosis and therapy of MEN type 1 and type 2. $J$ Clin Endocrinol Metab 2001; 86: 5658-5671. 
Marx SJ, Agarwal SK, Kester MB, Heppner C, Kim YS, Emmert-Buck MR, et al. Germline and somatic mutation of the gene for multiple endocrine neoplasia type 1 (MEN 1). J Intern Med 1998;243:447-5301; 61: 916-920.

Marx SJ. Molecular genetics of multiple endocrine neoplasia types 1 and 2 . Nat Rev Cancer. 2005; 5:367-375.

Marx, S. J.; Agarwal, S. K.; Heppner, C.; Kim, Y. S.; Kester, M. B.; Goldsmith, P. K. et al. The Gene for Multiple Endocrine Neoplasia Type 1. Bone, v.25, n.1, p. 119-22, 1999

Metz, D. C.; Jensen, R. T.; Bale, A. E.; Skarulis, M. C.; Eastman, R. C.; Nieman, L. et al. Multiple Endocrine Neoplasia Type I: clinical features and management. In: 1994

Meyer Bk, Petrulis Jr, Perdew Gh. Aryl Hydrocarbon (Ah) Receptor Levels Are Selectively Modulated By Hsp90-Associated Immunophilin Homolog Xap2. Cell Stress Chaperones. 2000 Jul;5(3):243-54.

Montenegro, F ; Neves, M. C. ; TAvares, M. R. ; Cordeiro, A. C. ; LourencoJr, D. M. ; Cunha Neto, M. B. ; Toledo, S. P. A. ; Pereira, M. A. A. ; Mendonca, B. B. ; Ferraz, A. R. . Abordagem do Hiperparatireoidismo (HPT) na Neoplasia Endócrina Multipla Tipo-1 (NEM-1). In: XX Congresso Brasileiro de Cirurgia de Cabeça e Pescoço, 2005, Salvador. XX Congresso Brasileiro de Cirurgia de Cabeça e Pescoço, 2005.

Nakamura Y. Larsson C. Julier C. et al. Localization of the genetic defect in multiple endocrine neoplasia type 1 within a small region of chromosome 11. Am J Hum Genet 1989; 44:751-755

Olufemi SE, Green JS, Manickam P, Guru SC, Agarwal SK, Kester MB, et al. Common ancestral mutation in the MEN 1 gene is likely responsible for the prolactinoma variant of MEN 1 (MEN 1 Burin) in four kindreds from Newfoundland. Hum Mutat 1998;11:264-9

Pellegata, N.S., Quintanilla-Martinez, L., Siggelkow, H., Samson, E., Bink, K., Hofler, H., Fend, F., Graw, J. \& Atkinson, M.J. (2006) Germline mutations in p27Kip1 cause a multiple endocrine neoplasia syndrome in rats and humans. Proceedings of the National Academy of Sciences of the United States of America, 103, 15558-15563. 
Samaan NA, Ouais S, Ordonez NG, Choksi UA, Sellin RV, Hickey RC. Multiple endocrine syndrome type I. Clinical, laboratory findings, and management in five families. Cancer. 1989; 64 (3):741-52.

Scappaticci S, Maraschio P, del Ciotto N, Fossati GS, Zonta A, Fraccaro M. Chromosome abnormalities in lymphocytes and fibroblasts of subjects with multiple endocrine neoplasia type 1. Cancer Genet Cytogenet. 1991 Mar;52(1):85-92.

Schussheim, D. H.; Skarulis, M. C.; Agarwal, S. K.; Simonds, W. F.; Burns, A. L.; Spiegel, A. M.; Marx, S. M. Multiple Endocrine Neoplasia Type 1: new clinical and basic finding. Trends Endocrinol. Metab., v. 12, n. 4, p. 173-8, 2001

Shiraso S, Katayose Y, Yamamoto K, Mizuma M, Yabuuchi S, Oda A, Rikiyama T, Onogawa T, Yoshida H, Hayashi H, Ohtsuka H, Motoi F, Egawa S, Kato J, Unno M. Overexpression of adenovirus-mediated p27kip1 lacking the Jab1-binding region enhances cytotoxicity and inhibits xenografted human cholangiocarcinoma growth. Anticancer Res. 2009 Jun;29(6):2015-24.

Tannapfel A, Grund D, Katalinic A, Uhlmann D, Köckerling F, Haugwitz U, Wasner M, Hauss J, Engeland K, Wittekind C. Decreased expression of p27 protein is associated with advanced tumor stage in hepatocellular carcinoma. Int J Cancer. 2000 Jul 20;89(4):350-5.

Teh B T Thymic carcinoids in Multiple Endocrine Neoplasia Type 1. J Intern Med 1998; 243:501-504.

Teh BT, McArdle J, Chan SP, Menon J, Hartley L, Pullan P, et al. Clinicopathologic studies of thymic carcinoids in multiple endocrine neoplasia type 1. Medicine (Baltimore). 1997; 76 (1):21-9.

Thakker RV. Bouloux P. Wooding C. et al. Association of parathyroid tumors in multiple endocrine neoplasia type 1 with loss of alleles on chromosome 11 N Engl J Med. 1989; 321:218-224 
Toledo RA, Lourenco DM, Coutinho FL, et al Novel MEN1 germline mutations in Brazilian families with multiple endocrine neoplasia type 1. Clin Endocrinol (Oxf). 2007b Sep;67(3):377-84. Epub 2007 Jun 6

Toledo RA, Lourenco DM, Coutinho FL, Quedas E, Mackowiack I, MACHADO MC, Montenegro F, Cunha-Neto MB, Liberman B, Pereira MA, Correa PH, Toledo SP. Novel MEN1 germline mutations in Brazilian families with multiple endocrine neoplasia type 1. Clin Endocrinol (Oxf). 2007

Toledo RA, Lourenco Jr DM, Coutinho FL, Quedas E, Longuini VC, Moraes $\mathrm{MB}$, et al. Estudo Gênico em pacientes com Neoplasia Endócrina Múltipla Tipo 1 (NEM-1). Arqu Bras Endocrinol Metab. 2006; (50): S497

Tomoda K, Kubota Y, Kato J. Degradation of the cyclin-dependent-kinase inhibitor p27Kip1 is instigated by Jab1. Nature. 1999;398:160-5.

Trump D, Farren B, Wooding C, Pang JT, Besser GM, Buchanan KD, et al. Clinical studies of multiple endocrine neoplasia type 1 (MEN1). QJM. 1996; 89 (9):653-69.

Vaidya B, Martina Owens, Sian Ellard. (2007) Analysis of gross deletions in the MEN1 gene in patients with multiple endocrine neoplasia type 1. Clinical Endocrinology. Online accepted.

Verges B, Boureille F, Goudet $P$, Murat A, Beckers A, Sassolas $G$, et al. Pituitary disease in MEN type 1 (MEN1): data from the France-Belgium MEN1 multicenter study. J Clin Endocrinol Metab. 2002; 87 (2):457-65.

Vierimaa O, Georgitsi M, Lehtonen R, et al. Pituitary Adenoma Predisposition Caused By Germline Mutations In The Aip Gene. Science. 2006 May 26;312(5777):1228-30.

Wilkinson, S., The, BT., Davey, KR., McArdle, J.P., Young, M\& Shepherd, JJ.. (1993) Cause of death in multiple endocrine neoplasia type 1. Archives of Surgery, 128,683-690.

Yazgan O, Pfarr CM. Differential binding of the Menin tumor suppressor protein to JunD isoforms. Cancer Res. 2001 Feb 1;61(3):916-20. 